\title{
TECNOLOGIAS E GESTÃO DO CONHECIMENTO NO TERRITÓRIO DE IDENTIDADE DE IRECÊ - TII
}

\section{ORGANIZADORES}

Livia da Silva Modesto Rodrigues

Paulo André da Rocha Perris 
Lívia da Silva Modesto Rodrigues

Paulo André da Rocha Perris

(Organizadores)

\section{Tecnologias e Gestão do Conhecimento no Território de Identidade de Irecê - TII}

1a Edição

Belo Horizonte

Poisson

2021 


\section{Editor Chefe: Dr. Darly Fernando Andrade}

\section{Conselho Editorial}

Dr. Antônio Artur de Souza - Universidade Federal de Minas Gerais

Ms. Davilson Eduardo Andrade

Dra. Elizângela de Jesus Oliveira - Universidade Federal do Amazonas

Msc. Fabiane dos Santos

Dr. José Eduardo Ferreira Lopes - Universidade Federal de Uberlândia

Dr. Otaviano Francisco Neves - Pontifícia Universidade Católica de Minas Gerais

Dr. Luiz Cláudio de Lima - Universidade FUMEC

Dr. Nelson Ferreira Filho - Faculdades Kennedy

Ms. Valdiney Alves de Oliveira - Universidade Federal de Uberlândia

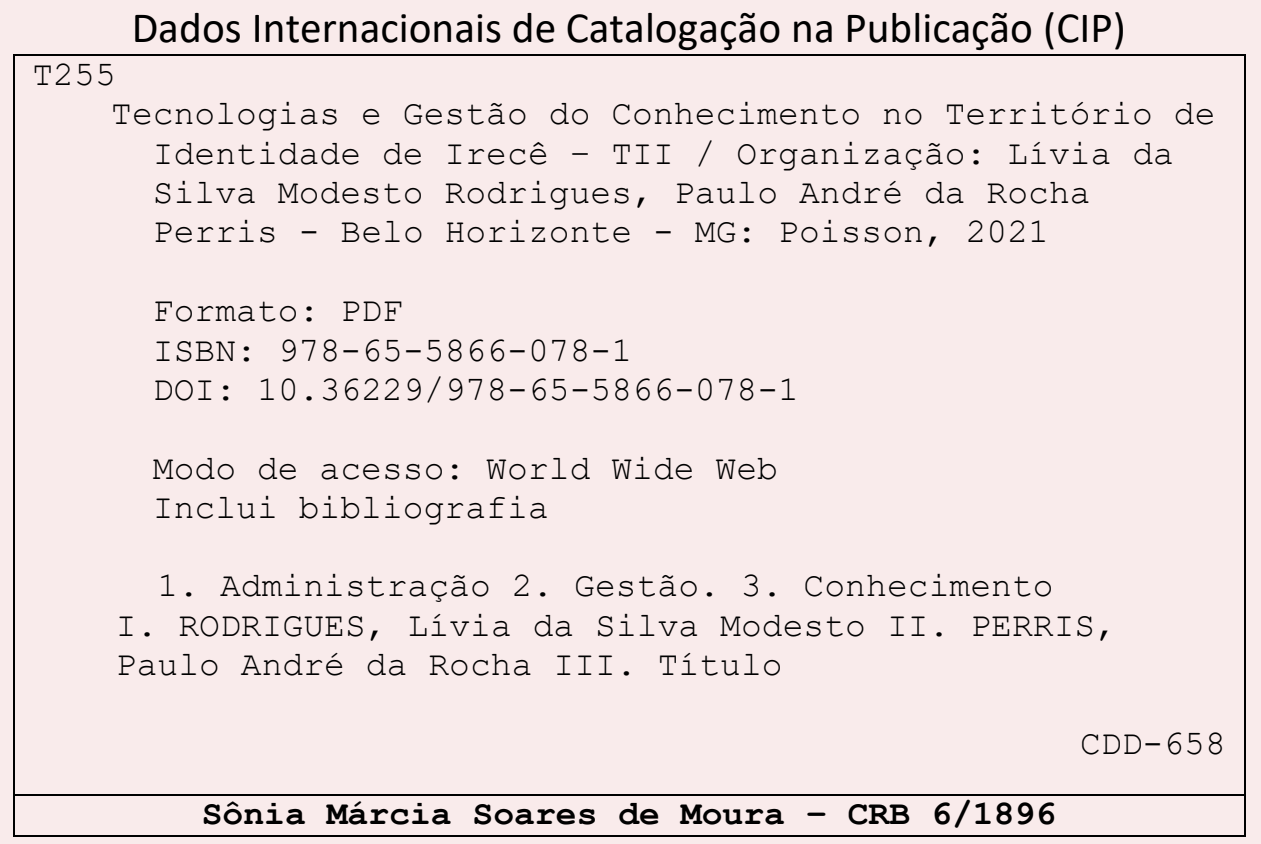

O conteúdo deste livro está licenciado sob a Licença de Atribuição Creative Commons 4.0.

Com ela é permitido compartilhar o livro, devendo ser dado o devido crédito, não podendo ser utilizado para fins comerciais e nem ser alterada.

O conteúdo dos artigos e seus dados em sua forma, correção e confiabilidade são de responsabilidade exclusiva dos seus respectivos autores.

www.poisson.com.br

contato@poisson.com.br 


\section{Sobre os Organizadores}

\section{Lívia da Silva Modesto Rodrigues}

Pós-doutorado realizado pela Universidade Portucalense/Universidade Salvador em Estudos Interdisciplinares sobre Políticas Públicas Promotoras de Igualdades (2019), Doutora em Geologia pela Universidade Federal da Bahia (2016), Mestre em Contabilidade pelo Centro de Pós-graduação e Pesquisa Visconde de Cairu - (2004), Especialista em Auditoria Fundação Visconde de Cairu (1998), Especialista em Impactos e Recuperação de Áreas Degradadas - Universidade Salvador (2014), Graduada em Ciências Contábeis - Universidade Salvador (1993) e em Administração de Empresas Faculdade Batista Brasileira (2007). Professora Adjunta da Universidade do Estado da Bahia e Coordenadora de Tutoria dos Cursos de Administração Pública (2015-2018) e Professora do Instituto Federal de Educação, Ciência e Tecnologia da Bahia. Possui experiência em Coordenação de Curso Superior nas modalidades Presencial e à Distância na área de Ciências Contábeis e Administração Pública.

\section{Paulo André da Rocha Perris}

Doutorado em Ciências da Computação pela Universidade Federal de Pernambuco, possui Mestrado em Ciências da Computação pela Universidade Federal de Pernambuco - UFPE (2013). Graduação em CTRA - Curso Tecnólogo em Redes e Ambientes Operac. pela União dos Institutos Brasileiros de Tecnologia - UNIBRATEC (2007). Tem experiência na área de Ciência da Computação, com ênfase em Educação Tecnológica EAD, atuando principalmente nos seguintes temas: EaD, Mídias Educacionais, acessibilidade, aprendizado colaborativo, sistemas operacionais, redes de computadores, redes hibridas. 


\section{Apresentação}

O principal registro das riquezas culturais, educacionais e científicas de um povo está nos diversos instrumentos disponibilizados através da escrita. Muitos trabalhos e pesquisas realizadas se perdem no tempo por falta de registro adequado e disseminação das informações e resultados obtidos. A divulgação dos resultados dos trabalhos científicos são primordiais para que os benefícios descobertos ou criados se tornem de fato usufruto da sociedade.

A proposta deste livro é ser um registro territorial de trabalhos científicos realizados por diversos pesquisadores das nossas instituições de ensino e pesquisa da região, tornando-se uma referência para futuras pesquisas e fonte histórica dos diversos acontecimentos e trabalhos realizados que influenciam e afetam o Território de Identidade de Irecê - TII.

Os trabalhos apresentados neste livro abordam pesquisas em diversas áreas do conhecimento, demonstrando a pluralidade dos temas estudados e resultados produzidos por nossos pesquisadores em nossas instituições de ensino. Assim, percebemos o potencial do Território de Irecê para a pesquisa e a inovação nas diversas áreas de conhecimento, e o quanto os resultados dos trabalhos são primordiais para o desenvolvimento socioeconômico, científico e cultural local.

Como propósito complementar, este livro também faz parte de um planejamento territorial que busca a implantação de um Programa de Mestrado Profissional, Interdisciplinar e Interinstitucional - envolvendo a Universidade do Estado da Bahia - UNEB, DCHT Campus XVI / Irecê e o Instituto Federal de Educação, Ciência e Tecnologia da Bahia - IFBA / Irecê - com vistas a promover a pesquisa científica, inovadora, com o intuito de possibilitar transformações sociais, econômicas, políticas, científicas e culturais, formando mestres que possam contribuir com o atendimento das necessidades profissionais das diversas áreas de conhecimento que permeiam o Território de Identidade de Irecê - TII, face às demandas de qualificação e formação profissional existente.

Esta proposição visa garantir uma atuação consistente, coerente e integrada na busca do fortalecimento e da democratização do ensino superior, estando comprometidos com a redução/superação das desigualdades sociais em um território de um povo sertanejo que historicamente é desassistido de oportunidades relativas à qualificação profissional e estímulo à pesquisa científica.

Esperamos que as análises e reflexões apresentadas nesta obra possam contribuir efetivamente para o fortalecimento do Território de Identidade de Irecê - TII através dos estudos que envolvem as categorias de análise referente às Tecnologias e Gestão do Conhecimento.

Jeime Nunes de Andrade Professor EBTT IFBA/Campus Irecê Mestre em Ciência da Computação
Ana Karine Loula Torres Rocha

Universidade do Estado da Bahia - UNEB /Campus XVI Doutora em Educação e Contemporaneidade 


\section{SUMÁRIO}

Capítulo 1: Gestão em foco: colaboração, autonomia e protagonismo estudantil na difusão do conhecimento em administração através de mídias sociais 07

André de Oliveira Alves, Bruna da Silva Gomes, Ana Karine Loula Torres Rocha

DOI: 10.36229/978-65-5866-078-1.CAP.01

Capítulo 2: Gestão na educação profissional e seus reflexos para a melhoria dos resultados no ensino e na aprendizagem. 24

Ithany Felipe Alcântara da Silva, Ana Karine Loula Torres Rocha

DOI: 10.36229/978-65-5866-078-1.CAP.02

Capítulo 3: A influência de variáveis manipuláveis em testes de usabilidade na realização de atividades computacionais envolvidas no desenvolvimento de tecnologia assistiva de baixo custo 41

Paulo André da Rocha Perris, Fernando da Fonseca de Souza

DOI: 10.36229/978-65-5866-078-1.CAP.03

Capítulo 4: Gestão socioambiental: Um estudo das ações desenvolvidas pela gestão pública do município Novo Horizonte-BA para promover a sustentabilidade socioambiental da atividade mineral no garimpo do quartzo rutilado 54

Manoela Fernanda Pereira da Silva, Lívia da Silva Modesto Rodrigues, André Luiz Rocha de Souza, Alexandre José Alves da Silva

DOI: 10.36229/978-65-5866-078-1.CAP.04

Capítulo 5: Bionegócios: perspectivas de desenvolvimento do território de identidade de Irecê 71

Cleiton Braga Saldanha, Jerisnaldo Matos Lopes, Karine Santiago Santos

DOI: 10.36229/978-65-5866-078-1.CAP.05

Capítulo 6: Implantação do parque eólico no município de Morro do Chapéu: Uma análise dos aspectos ambientais, sociais e econômicos . .88

Tácio Reis Dias Pereira Valois, Livia da Silva Modesto Rodrigues

DOI: 10.36229/978-65-5866-078-1.CAP.06

Capítulo 7: Literatura infantil: Uma análise acerca da mediação tecnológica como suporte na contações de histórias 111

Aline Silva Santos, Ediane Oliveira dos Santos, Daniela Lopes Oliveira Dourado

DOI: 10.36229/978-65-5866-078-1.CAP.07

Autores: 


\section{Capítulo 1}

Gestão em foco: colaboração, autonomia e protagonismo estudantil na difusão do conhecimento em administração através de mídias sociais

André de Oliveira Alves

Bruna da Silva Gomes

Ana Karine Loula Torres Rocha 


\section{APRESENTAÇÃO}

A pesquisa na Universidade precisa ser um processo interdisciplinar, educativo, cultural, científico e político que promova a interação entre a Universidade e outros setores da sociedade e por isso precisa estar articulado com o ensino e a extensão. Para tanto, as ações de pesquisa e extensão devem fazer parte do percurso acadêmico do discente, possibilitando-lhes autonomia e protagonismo para que experimentem uma formação integral, interdisciplinar e indissociável entre ensino, pesquisa e extensão.

As Tecnologias da Informação e Comunicação (TIC) devem ser incluídas em processos formativos como instrumentos a serviço de um ensino voltado para a emancipação dos sujeitos, por isso propusemos o uso das mídias sociais não como um meio de comunicação de condução, mas como um meio de comunicação comprometido com o processo educativo, capaz de romper barreiras geográficas e sociais e contribuir com o processo de inclusão social, política e econômica da comunidade interna e externa da Universidade do Estado da Bahia - UNEB, Departamento de Ciências Humanas e Tecnologias - DCHT Campus XVI / Irecê.

Este trabalho, resultado de um projeto de pesquisa e extensão, buscou proporcionar aos discentes a oportunidade de vivenciar situações de seu campo de formação, ampliando os conhecimentos teórico-práticos construídos durante o curso, além de analisar as condições observadas em espaços profissionais com base nos conhecimentos adquiridos, sendo capazes de propor soluções para os problemas identificados, ajudando o pequeno empreendedor, comerciante, empresas de pequeno, médio e grande porte a gerir seu empreendimento através de orientações, dicas, informes e entrevistas.

As linhas temáticas foram definidas a partir da organização estabelecida pelas linhas do Grupo de Pesquisa em Administração e Desenvolvimento Territorial - GP ADT / CNPq da qual este trabalho também está vinculado, sendo estes: 1) Gestão Organizacional; 2) Gestão Solidária, Cidadania e Sustentabilidade; e 3) Empreendedorismo, Inovação e Tecnologias Organizacionais.

Para tanto optamos por utilizar uma abordagem qualitativa do tipo exploratória, a partir da pesquisa-ação e considerando a natureza do objeto o definimos como teóricoempírico. A metodologia da pesquisa-ação é considerada um sistema aberto porque diferentes caminhos podem ser definidos no decorrer do seu desenvolvimento em 
função das demandas encontradas. Inicia-se com um planejamento conforme afirma Thiollent (2011), há um ponto de partida, que é a fase exploratória, e um ponto de chegada, referindo-se à divulgação dos resultados, mas no intervalo haverá uma multiplicidade de caminhos em função das diferentes situações diagnosticadas ao longo do processo.

Gil (2005) aponta que através da pesquisa e intervenção as pessoas envolvidas em determinada problemática e que participam da busca de soluções beneficiam-se não só com os resultados, mas também durante seu desenvolvimento, envolver grupos sociais na resolução de seus problemas permite também integrar ensino, pesquisa e extensão (SANTOS, 2004; TOZONI-REIS, 2007).

Ao destacar seu caráter reflexivo, mobilizador, gerador de conhecimentos interdisciplinares e de soluções coletivas, a pesquisa-ação mostra-se com forte potencial de contribuição em processos de transformação das práticas institucionais, bem como no desenvolvimento da cidadania e do empoderamento, considerado elementos essenciais para a mediação de situações de conflito.

Consideramos que a ação extensionista é um ato educativo e participativo que permite o diálogo de conhecimentos com fins transformadores, consubstanciada com o ensino, a pesquisa e a tecnologia como parte atuante da extensão universitária e viceversa, bem como para a formação do profissional em administração, possibilitando também a estes estudantes qualificar-se para estudos posteriores em nível de PósGraduação.

Desenvolver este trabalho é também relevante para a compreensão, construção e indicação de alternativas que possam refletir numa melhoria dos processos formativos, a partir da contribuição da universidade pública, considerando sua função social, política e científica na construção e socialização de conhecimentos, uma vez que seu compromisso precisa estar atrelado também com a redução das desigualdades sociais e superação dos desafios e demandas contemporâneas.

Este estudo está vinculado ao Grupo de Pesquisa em Administração e Desenvolvimento Territorial - GP ADT / CNPq da Universidade do Estado da Bahia UNEB / DCHT, Campus XVI Irecê/BA. Foi apoiado pelo Edital 023/2019, referente ao aviso no 026/2019, publicado no D.O.E. de 20/03/2019, que trata de processo seletivo de projetos de extensão e concessão de bolsas de monitoria de extensão e também do 
Edital 014/2019, referente ao aviso no 016/2019, publicado no D.O.E. de 29/01/2019, que trata de concessão de bolsas de Iniciação Científica - IC e IC voluntário do PICIN / UNEB, ambos vinculados a Universidade do Estado da Bahia - UNEB.

\section{EXTENSÃO UNIVERSITÁRIA}

A discussão sobre a importância da universidade na construção e transformação da sociedade tem ganhado cada vez mais espaço nos debates acadêmicas e produções científicas, motivando o aperfeiçoamento das práticas universitárias. Frente a essa situação, a extensão universitária, se constitui um canal mais direto em estabelecer relação entre a universidade e sociedade, podendo atuar de forma mais incisiva sobre as questões sociais.

A Extensão Universitária surgiu na Inglaterra, no século XIX, como educação continuada, destinada à população adulta que não tinha acesso à universidade (NOGUEIRA, 2005). Corroborando, Carneiro (1985, p. 28) afirma que,

(...) a extensão surge como subproduto da Revolução Industrial Inglesa, no século XIX, numa pedagogia para educação de adultos, no formato de cursos oferecidos fora do horário de trabalho (turno noturno), cujo tema estava estreitamente ligado à profissão. Na Inglaterra, a universidade cria um departamento com a denominação de extensão universitária para formação de adultos, que tratava a extensão como iniciativas culturais e educativas da universidade para atender adultos analfabetos.

De acordo com Serrano (2013, p. 14), foi nessa época que passou a exigir das universidades uma maior demanda sobre as questões da sociedade,

uma nova concepção de educação, surgindo no século XIX, leva as universidades a se preocuparem com a prestação de serviços que deveriam oferecer às comunidades. Essa nova concepção apresentava a necessidade de uma educação continuada, que não terminasse na infância, mas seguisse por toda a vida.

No Brasil, os primeiros registros oficiais sobre extensão são encontrados no Estatuto da Universidade Brasileira / Decreto-Lei nº 19.851, de 1931 e na Lei de Diretrizes e Bases da Educação Nacional no 4.024, de 1961, centrados na modalidade de transmissão de conhecimentos e assistência (CASTRO, 2019).

De acordo com Gadotti [s.d.], só no início da década de 1960 que a extensão se tornou como a conhecemos hoje, indissociável do ensino e da pesquisa, tomou corpo quando surgiram ações de compromisso com as classes populares, com a 
intencionalidade de conscientizá-las sobre seus direitos.

O Fórum de Pró-Reitores de Extensão das Universidades Públicas Brasileiras (2010), compreende a extensão universitária como a relação mais direta entre a universidade e outros setores da sociedade, entendida como um processo interdisciplinar educativo, cultural, científico e político, articulada ao Ensino e Extensão sob o princípio da indissociabilidade. De uma forma mais abrangente a universidade atua sobre as questões sociais de maneira planejada e orientada, visando a resolução das problemáticas locais existentes, a partir do incentivo aos "agentes locais". Mediante tal postura, a universidade assume papel importante na sociedade a partir da atuação sobre as questões sociais, assim como afirma a Forproex (2013), que, sem praticar a extensão, isolada em seus muros, a universidade perde o rumo.

Dessa maneira, a prática extensionista é considerada essencial para a formação de estudantes do ensino superior na medida em que proporciona experiências diretas com o contexto social no qual está inserido, além de praticar a função social que se espera da universidade na luta pela garantia de direitos necessários da sociedade.

\section{DIFUSÃO DE CONHECIMENTOS ATRAVÉS DAS FERRAMENTAS TECNOLÓGICAS}

A revolução tecnológica ocasionada pelo advento das novas tecnologias da informação e comunicação proporcionaram uma série de ferramentas que viabilizaram a sociedade o acesso ilimitado à informação, acarretando uma série de inovações no qual permitiu o ser humano acessar qualquer conteúdo de forma rápida e segura (TAKASE, 2007). A tecnologia da informação é um dos fatores preponderantes na "nova" sociedade, sendo considerado fator de poder e mudança social.

Estes constantes avanços dos elementos tecnológicos revolucionaram significativamente o cotidiano das pessoas, tais como a forma de pensar, comunicar, tomar decisões e resolver problemas. Entretanto, segundo Silva, Correia e Lima (2010, p. 215), “o sistema ideológico reage como forma de corroborá-la ou negá-la, sintonizando o indivíduo no mundo com sua capacidade semântica", ou seja, na dinâmica do mundo moderno, os indivíduos são submetidos a um aglomerado de informações, diante disso, estes necessitam serem capazes de recepcionar, construir e gerar informações, utilizando a sua criticidade. 
De acordo com Takase (2007), a sociedade da informação preconiza a disseminação geral das tecnologias da informação e comunicação para que todos possam usufruir e consequentemente transformá-las em conhecimento. Os autores Oliveira et al. (2015 apud DEMO, 2007) expõem que é imprescindível que a revolução tecnológica atinja os indivíduos de forma plena, dessa forma contribuindo para a construção de uma sociedade mais justa, condicionando oportunidades individuais, sociais, socioeconômica, políticas ou socioculturais.

A sociedade da informação, é caracterizado por Takase (2007, p. 35) como uma nova forma de organização de pessoas, empresas e governo, que tem a informação como ativo principal, é denominada também como "sociedade do conhecimento", a troca de saberes, informações/conhecimentos em prol do próximo é o principal objetivo. Porém, diante das desigualdades sociais, econômicas e culturais muitas pessoas não possuem acesso às informações essenciais para a inserção na sociedade do conhecimento.

No decorrer do século $\mathrm{XX}$, os meios de comunicação tais como: filmes, rádio, gravador, televisão, computador, entre outros, foram fortemente utilizados, cada ferramenta de comunicação possuiu seu papel transformador na sociedade, principalmente nos processos formativos. As ferramentas digitais influenciaram elementos significativos do processo ensino/aprendizagem, sendo um deles a gestão do conhecimento.

Segundo Fernandes (2019), a gestão do conhecimento é oriundo da informação e pode ser definida como o processo de criar, compartilhar e gerenciar o conhecimento. Os autores Oliveira et al. (2015 apud MOTA; SCOTT, 2014), relatam que o "modo como o conhecimento é inicialmente produzido e transformado está se alterando significativamente, o que traz como consequência a necessidade de uma nova revolução educacional, da qual venham surgir novas abordagens e tecnologias de ensinar e de aprender". Os autores se referem a dinamicidade das transformações e aperfeiçoamento das tecnologias disponíveis com o objetivo de simplificar o cotidiano das pessoas e organizações. Nesse contexto, os autores mostram a importância da inclusão das tecnologias no meio educacional, e na maioria das vezes, a comunidade acadêmica não compreendem o impacto que essas tecnologias acarretam em suas práticas e trabalho educacional.

Conforme Oliveira et al. (2015), na tentativa de resolver as problemáticas 
existentes, professores e alunos têm a possibilidade de usar as tecnologias da informação e comunicação para trocar, disseminar e construir conhecimentos, na perspectiva de favorecer o desenvolvimento pessoal, profissional e grupal, bem como, compreender a situação atual no qual estão inseridos (apud ALMEIDA, 2001).

Dessa forma, por meio das mídias sociais, espaços são construídos, propiciando a interação e a aprendizagem, caracterizadas como "desafiadoras", interativas e colaborativas. Assim, a tecnologia quando utilizada como ferramenta no processo de ensino/aprendizagem e na disseminação de saberes, contribuem para o surgimento de novos ambientes de aprendizagem, substituindo a pedagogia rígida tradicional por uma pedagogia virtual colaborativa (OLIVEIRA et al. 2015 apud TYBUSCH, J. S.; TYBUSCH, 2013).

Segundo Ferreira (2017), as pessoas, organizações públicas ou privadas devem se adequar às transformações na sociedade, principalmente no que diz respeito a inovação e ferramentas tecnológicas, pois, estas proporcionam a evolução e a revolução. Caso não consigam acompanhar as mudanças e o ritmo, ficarão desatualizados e fora do contexto social. 0 autor afirma que o diferencial é criar meios inteligentes, investir em pesquisas, inovação, integrar sistemas e oferecer soluções.

É importante ressaltar o papel da Universidade com relação ao compromisso social na expansão de saberes com embasamento científico o qual, professores e alunos têm o dever de disseminar o conhecimento produzido na academia com a comunidade. Portanto, segundo Fernandes, Silva e Machado (2012 apud LIMA, 2003), a Universidade deve estar inserida na comunidade, para que assim, possa realizar a troca de experiência, proporcionando consequentes mudanças, superando assim problemáticas enfrentadas pelas pessoas.

Atualmente, as pessoas se tornaram reféns da tecnologia devido a Pandemia decorrente do novo Corona Vírus (Covid-19). As pessoas, organizações e o Governo tiveram que de imediato se adaptar às novas mudanças decorrente da política do isolamento social indicado pela Organização Mundial de Saúde (OMS). Dessa forma, as ferramentas tecnológicas foram apontadas como a principal opção para a manutenção da dinamicidade rotineira (MORAIS, 2020). É imprescindível a inserção e adequação das tecnologias, principalmente para os empreendimentos de pequeno porte que desejam manter suas vendas nesse período. Nessa perspectiva, as Universidades têm a 
responsabilidade e o compromisso de disseminar saberes para auxiliá-los nesse momento de pandemia.

\section{RESULTADOS E DISCUSSÃO}

O projeto Gestão em Foco: colaboração, autonomia e protagonismo estudantil a partir da socialização de conhecimentos em administração, através da rádio e mídias sociais, com apoio extensionista (edital n 023/2019) e de Iniciação Científica (edital n ${ }^{\circ}$ 014/2019) é uma realização dos estudantes do curso de Bacharelado em Administração, Campus XVI - Irecê da Universidade do Estado da Bahia (UNEB), com orientação docente, tendo como objetivo a vivência de experiências formativas de caráter interdisciplinar, articulado com o ensino, a pesquisa e a extensão, por meio da socialização de conhecimentos vinculados à administração, através das mídias sociais, visando ajudar o pequeno empreendedor, comerciante, empresas de pequeno, médio e grande porte a gerir seu empreendimento através de orientações, dicas, informes e entrevistas.

A figura 01 mostra a participação dos integrantes do projeto "Gestão em Foco" no I Seminário científico de Administração do Campus XVI - Irecê, da UNEB, o qual apresentaram os primeiros resultados da respectiva pesquisa de caráter extensionista.

Figura 01 - Discentes do curso de Administração do DCHT - Campus XVI apresentando o Projeto “Gestão em Foco” no I Seminário Científico de Administração.

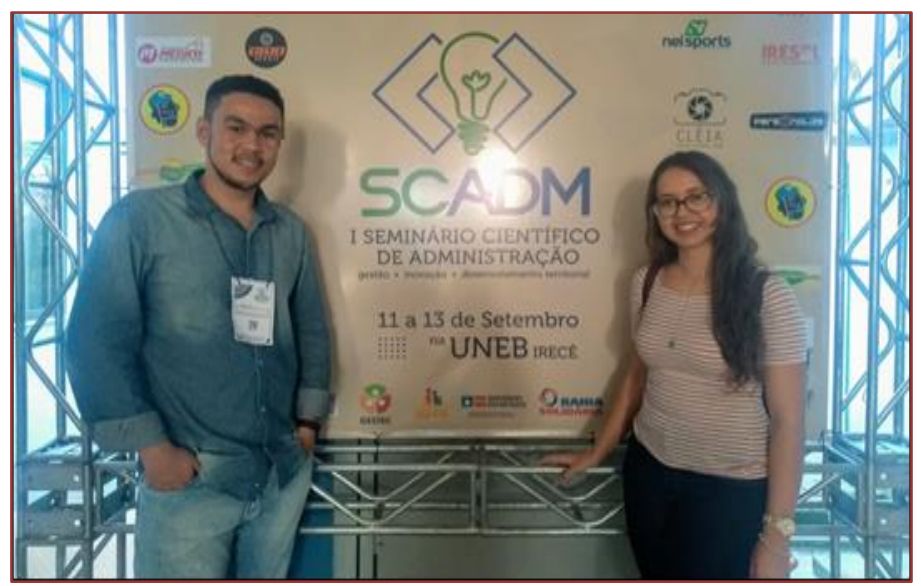

Fonte: Acervo pessoal dos pesquisadores, 2019. 
O TII é composto por 20 municípios, sendo eles: América Dourada, Barra do Mendes, Barro Alto, Cafarnaum, Canarana, Central, Gentio do Ouro, Ibipeba, Ibititá, Ipupiara, Irecê, Itaguaçu da Bahia, João Dourado, Jussara, Lapão, Mulungu do Morro, Presidente Dutra, São Gabriel, Uibaí e Xique-Xique. Segundo o Plano Territorial Desenvolvimento Rural Sustentável (PTDRS, 2010). O município de Irecê é polo comercial e estende todo o seu território, concentrando um número significativo de empresas/empreendimentos, segundo a Receita Federal do Brasil (2020), são 9.094 empresas atuantes no mercado Ireceense.

Mapa 1 - Território de Identidade de Irecê (TII)

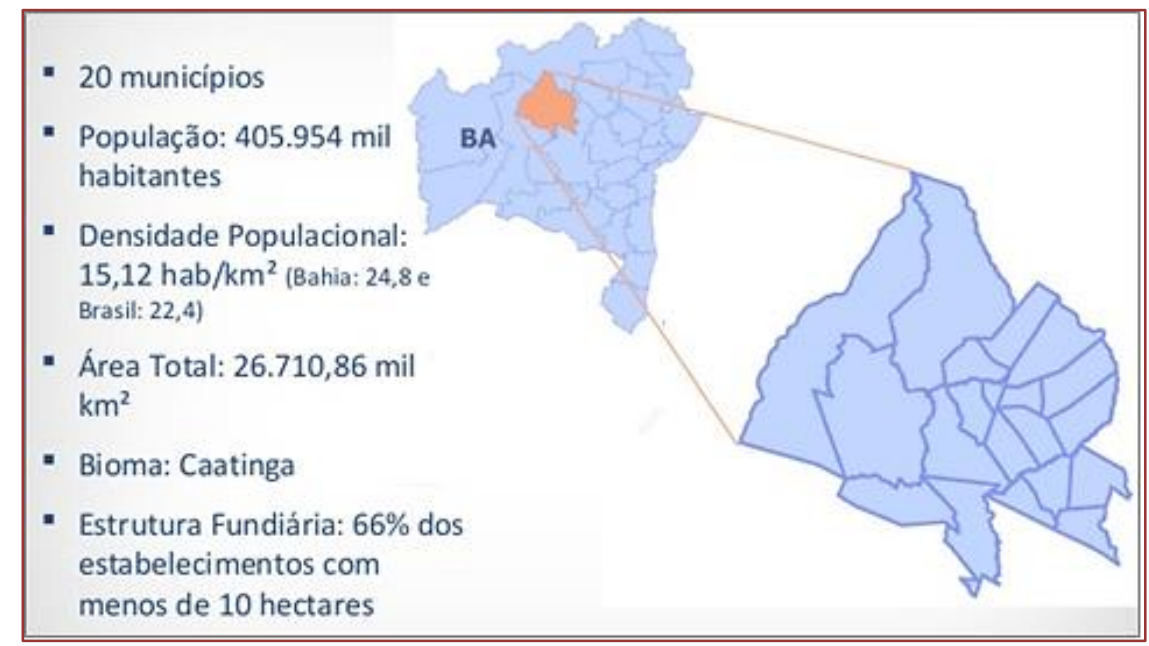

Fonte: BAHIA. Secretaria do Planejamento do Estado da Bahia. Caracterização: Território Irecê. Salvador, 2012. Reprodução: Google. Disponível em: <https://image.slidesharecdn.com/apresentaoirece05130726092053-phpapp02/95/apresentao-irece-0506-4-638.jpg?cb=1374830552>. Acesso em: 08 nov. 2017.

Para o desenvolvimento do projeto, as ações realizadas seguiram orientações previamente planejadas, com estudos teóricos que envolvem as discussões relativas às linhas temáticas de pesquisa: 1) Gestão Organizacional; 2) Gestão Solidária, Cidadania e Sustentabilidade; e 3) Empreendedorismo, Inovação e Tecnologias Organizacionais, e na sequencia foi realizada a coleta de dados e informações no comércio local, para o levantamento das dificuldades enfrentadas pelos pequenos empreendedores no seu diaa-dia, visando obter o norteamento das discussões que sucederam nas produções das matérias a serem veiculadas nas mídias sociais. 
Mediante a pesquisa e os estudos realizados em conjunto com a supervisão docente, foi decidido visitar inicialmente os pequenos empreendedores da cidade de Irecê, visto que, estes são os que enfrentam maiores dificuldades em gerir seu negócio. Com isso, foi produzido um questionário com seis (06) perguntas subjetivas e objetivas, com a intenção principal de identificar as principais dificuldades enfrentadas pelos comerciantes. Foram visitados quinze (15) empreendimentos localizados sobretudo no centro da cidade de Irecê, nos quais os respectivos gerentes responderam o questionário.

Com o objetivo de compreender os desafios enfrentados pelos pequenos e médios empreendedores, foi questionado sobre as principais problemáticas enfrentadas no cotidiano da empresa. 0 questionário foi elaborado considerando opções de múltipla escolha, podendo marcar mais de uma alternativa. Na figura 02 mostramos o resultado do questionário utilizado na entrevista.

Figura 02 - Entrevista realizada com os comerciantes de Irecê

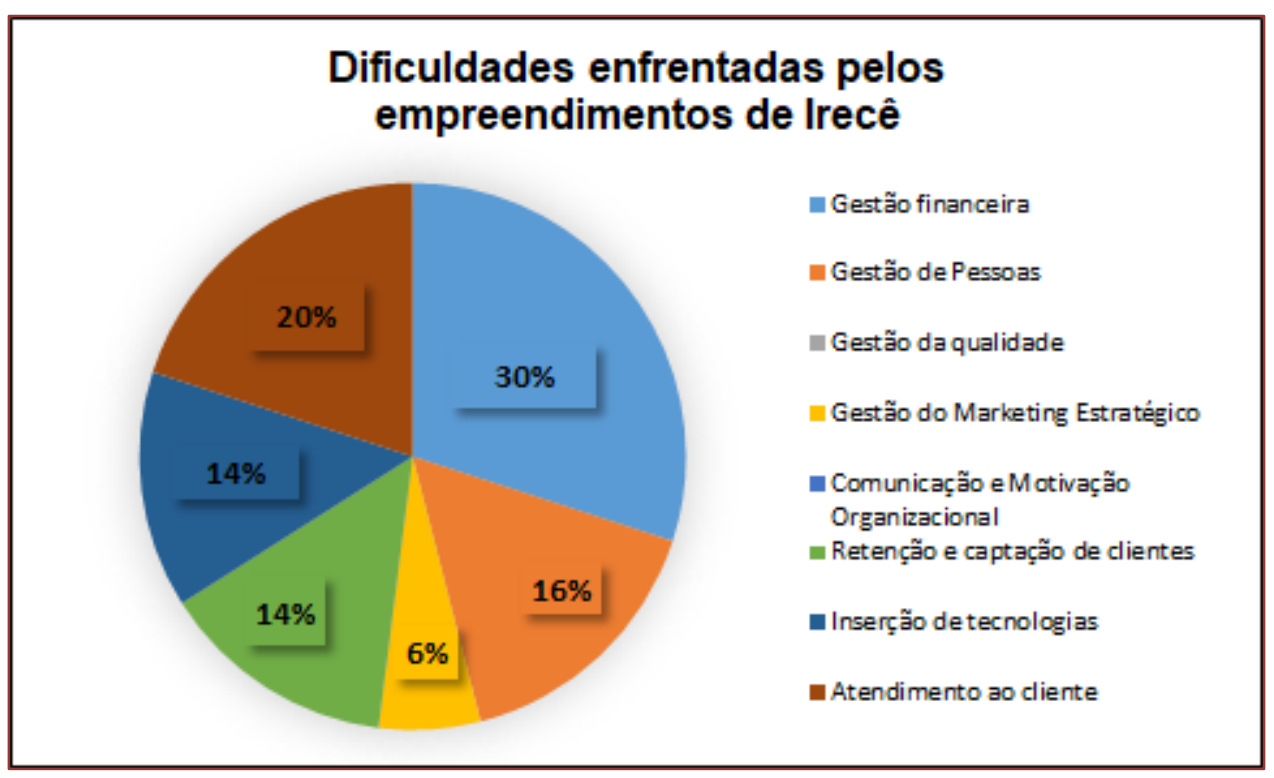

Fonte: Autores do trabalho, 2019. 
Foi possível identificar que a problemática existente no comércio de Irecê consiste principalmente na gestão financeira: foram relatados as dificuldade da captação de recurso junto aos bancos, e aplicação dos conceitos da administração financeira no gerenciamento das contas; o segundo problema existente foi o atendimento ao cliente, esse quesito foi justificado pela necessidade da contratação de colaboradores que saibam se comunicar com seus clientes, assim fidelizando-os, buscando reter e captar novos clientes, reconheceram como fundamental a gestão de pessoas na organização, pois o recrutamento e seleção dos colaboradores foi visto como a essência de uma boa equipe.

A inserção das tecnologias obteve 14\%, neste ponto foi observado que os pequenos empreendimentos fazem pouco uso das tecnologias e das plataformas digitais para a divulgação dos produtos e/ou serviços, percebeu-se que a maioria não vislumbra a expansão do negócio, apenas sobrevivem no mercado. 0 marketing Estratégico ficou com apenas 6\%, na entrevista, foi relatado o famoso "boca a boca" para a divulgação do empreendimento, ou seja, as ferramentas tecnológicas não são muito utilizadas.

Diante disso, percebe-se que a gestão financeira e a gestão organizacional foram as temáticas mais apontadas pelos pequenos empreendedores, uma vez que, o investimento financeiro é essencial para o desenvolvimento de qualquer negócio e a gestão organizacional é primordial para a alavancagem e permanência do empreendimento no mercado.

Em tempos de pandemia causada pelo novo Coronavírus (Covid-19), com as restrições de funcionamento dos empreendimentos locais e com as recomendações de isolamento/distanciamento social indicadas pelas autoridades de saúde, dentre elas a Organização Mundial da Saúde (OMS), Ministério da Saúde e secretarias de saúde de estados e municípios, houve a suspensão da possibilidade do uso da rádio (inicialmente também prevista para difusão do conhecimento construído), diante disso, para prosseguir com o andamento do projeto, optou-se com o uso das mídias sociais, em especial a plataforma Youtube para a divulgação das produções, uma vez que esta caracteriza uma estratégia comprometida com a difusão do conhecimento.

Para Torres (2009, p. 113), “as mídias sociais são sites na internet que permitem a criação e o compartilhamento de informações e conteúdos pelas pessoas e para as pessoas, nas quais o consumidor é ao mesmo tempo produtor e consumidor da 
informação".

O YouTube é um site de compartilhamento de vídeos enviados pelos usuários através da internet. Referente à plataforma, Burgess e Green (2009) afirmam que ela gira em torno de uma colaboração mútua entre todos os indivíduos envolvidos, porém a mesma não possui um papel de produtora de conteúdo, mas sim de agregadora de conteúdo. Já Oliveira (2017), afirma que o conteúdo veiculado nessa plataforma é transmitido de forma descontraída e faz com o que o consumidor, neste caso o internauta, tenha acesso aos conhecimentos transmitidos sem ter que fazer o exercício de uma leitura formal, que nem sempre é compreendida por todos. Torres (2009) assevera que no planejamento é preciso definir quem é o público-alvo.

O projeto de Extensão e de Iniciação Científica: Gestão em Foco estabeleceu uma parceria com o Projeto Live UNEB Adm (LUA), para a divulgação das produções. 0 projeto LUA é uma iniciativa dos estudantes do curso de Bacharelado em Administração do Departamento de Ciências Humanas e Tecnologias, Campus XVI - Irecê, da Universidade do Estado da Bahia, que consiste na realização de lives com palestras semanais por meio da plataforma Youtube, onde recebe profissionais das diversas áreas do conhecimento para a discussão de temas relevantes para a sociedade, em especial à Covid-19 e suas implicações cotidianas.

Tendo em vista as dificuldades enfrentadas pelas empresas locais do TTI, no que diz respeito aos aspectos financeiros e econômicos identificados através da pesquisa de campo, foi realizada a palestra com o tema: "Pandemia da Covid-19 e Políticas Econômicas", sendo conduzida com uma abordagem histórica sobre a atuação do Estado na economia brasileira, além de apresentar perspectivas atuais.

Angardi (2016, p. 16) compreende que “a intervenção do Estado no domínio econômico pode ser entendida como todo ato ou medida legal que restrinja, condicione, controle ou elimine a iniciativa privada em determinada atividade econômica". Ainda segundo o autor, a atuação do Estado pode ocorrer como agente disciplinador ou pela participação como agente econômico, a depender dos princípios e objetivos sociais e econômicos delineados por determinada Constituição.

No cenário nacional com a pandemia provocada pelo novo coronavírus, a Comissão Econômica para a América Latina e o Caribe (Cepal) prevê que a economia brasileira encolherá 5,2\% em 2020 (MÁXIMO, 2020), o que também terá reflexo direto 
sobre as empresas locais do TII. Frente a isso requer do governo brasileiro uma postura mais incisiva visando a diminuição dos impactos para as empresas e seus reflexos na vida social.

No material intitulado "Medidas Oficiais para o Enfrentamento do Covid-19", versão consolidada referente ao dia 14/04/2020, publicado pelo Serviço Brasileiro de Apoio às Micro e Pequenas Empresas - Sebrae (2020), são apresentadas algumas medidas oficiais do Governo Federal para enfrentamento do Covid-19. Dentre as medidas, citam-se as financeiras e de crédito. No aspecto financeiro, a Federação Brasileira de Bancos (Febraban) informa que os cinco maiores bancos do Brasil, (Banco do Brasil, Bradesco, Caixa, Itaú Unibanco e Santander) anunciam a possibilidade de prorrogar as dívidas de clientes pessoa física e micro e pequenas empresas; e no quesito crédito, conforme a Resolução n⿳⺈ 4.798, de 6 de abril de 2020 instituiu linha de crédito especial com recursos dos Fundos Constitucionais de Financiamento do Norte (FNO), do Nordeste (FNE) e do Centro-Oeste (FCO) para pessoas físicas e pessoas jurídicas, incluindo cooperativas. Essa atuação do governo pode significar o apoio necessário para a permanência das empresas no mercado pós-pandemia.

Outra dificuldade identificada na pesquisa com os empreendedores de Irecê é referente a necessidade de uma atuação mais incisiva visando a divulgação e expansão do negócio, o que se caracteriza como a necessidade de estratégias de marketing. Tendo em vista que no cenário atual de pandemia, as empresas adotaram os meios digitais para a realização de suas campanhas publicitárias e todas as demais transações comerciais, mediante a isto, ocorreu a produção de uma palestra com o tema: "Marketing digital no cenário baiano", fazendo uma abordagem panorâmica sobre o marketing com o uso da tecnologia (redes sociais e mídias sociais) em especial no cenário do Estado da Bahia.

Para McCarthy (1982), marketing é o processo social no qual os fluxos de bens e serviços são direcionados aos consumidores de modo a equilibrar efetivamente a oferta e a procura. Dessa forma, o marketing digital pode ser entendido como uma estratégia adaptada para a internet, por meio da utilização de mídias sociais/redes sociais. Souza (2012), compreende que o marketing digital consiste na comunicação, com fim comercial, entre a empresa e o cliente, tendo como meio a internet e seus aplicativos. Ainda segundo o autor, o marketing digital tem um custo quase zero se comparado com outros do marketing tradicional. 
Tendo em vista as produções realizadas, fica evidente a importância de projetos dessa natureza para o desenvolvimento local. No decorrer do projeto "Gestão em Foco" se propõe a utilização de mecanismos para obter os indicadores de relevância das temáticas abordadas nas produções, com vistas ao aprimoramento dos processos de operacionalização e de desenvolvimento. As ações realizadas por meio do projeto de Extensão e Iniciação Científica "Gestão em Foco" e o projeto "LUA" promove uma interação direta entre a universidade e a sociedade, o que se configura essencial frente ao papel que se propõe a universidade, através de projetos de cunho extensionista que é o de atuar sobre as questões sociais.

\section{CONSIDERAÇÕES FINAIS}

No decorrer desse trabalho foi possível perceber a importância da internet e das ferramentas tecnológicas no cotidiano da sociedade sendo fator primordial para o desenvolvimento e continuidade das atividades cotidianas, principalmente nas áreas educativas e no mundo do trabalho. Contudo, é perceptível que, milhares de pessoas não possuem acesso à essas tecnologias, ficando desconectadas da dinamicidade do momento atual, correndo o risco de serem excluídos inclusive dos seus empregos.

Os reflexos da pandemia do Covid-19 impactam o modo de vida, a forma de pensar, a demanda por determinados produtos e serviços, o mundo está vivendo o novo paradigma tecnológico. As organizações que não investiram nesse ramo, certamente já estão sofrendo drasticamente as consequências, e estão percebendo a necessidade da emancipação do "antigo modelo de trabalho".

Os desafios tecnológicos contemporâneos estão intensificando cada vez mais a exclusão de todos aqueles que não tem acesso à essas ferramentas ou que ainda não se adaptaram aos novos padrões utilizados pelas organizações, portanto, é de extrema importância que as unidades de ensino em especial as universidades entrarem em ação, exercendo seu compromisso com a sociedade, fornecendo soluções imediatas para amenizar os reflexos dos novos desafios, como também, mostrar para a comunidade o seu papel enquanto Universidade pública, não mais limitado a formação profissional atendendo apenas às necessidades e demandas do mercado de trabalho, mas uma universidade que dispõem diversos dispositivos para a formação de profissionais competentes, capazes, que almejam transformar a realidade da sua comunidade e 
propor uma sociedade mais igualitária e mais humana.

Por meio do projeto de extensão e de iniciação científica: Gestão em Foco, se estabeleceu uma relação mais direta entre a universidade e a comunidade local, o que em aspectos de objetivos firmados inicialmente foram alcançados. Dessa forma, pode se considerar que a participação dos estudantes nesse projeto é essencial para a formação acadêmica e do sujeito social que a universidade se compromete a formar. Ademais, o projeto Gestão em Foco encontra-se em fase de desenvolvimento, passando por aprimoramentos permanentes na sua execução de maneira a alcançar com êxito os objetivos firmados.

\section{FOMENTO}

Os autores agradecem a Pró-Reitoria de Pesquisa e Ensino de Pós-Graduação (PPG) e a Pró-Reitoria de Extensão (PROEX), o Grupo de Pesquisa em Administração e Desenvolvimento Territorial - GP ADT / CNPq, a Universidade do Estado da Bahia (UNEB) pelo apoio ao projeto que originou a publicação deste trabalho.

\section{REFERÊNCIAS}

[1] ANGARDI, J. K. R. Intervenção do estado no domínio econômico: o papel do Conselho Administrativo de Defesa Econômica (CADE) e sua interface com a Agência Nacional de Telecomunicações (ANATEL) em atos de concentração no segmento de telefonia. Rio de Janeiro. 2016.

[2] BURGESS, J; GREEN, J. Youtube e a revolução digital: como o maior fenômeno da cultura participativa transformou a mídia e a sociedade. São Paulo: Aleph, 2009.

[3] CARNEIRO, M.A. Extensão universitária. Versão \& Perversões. Estudo tentativo de identificação do débito social das universidades federais do Nordeste. João Pessoa: Presença UFPB, 1985.

[4] CASTRO, A. M. de. Avaliação diagnóstica do programa de apoio a projetos de extensão do instituto federal de educação, ciência e tecnologia do Ceará. Dissertação apresentada ao Programa de Pós-Graduação em Políticas Públicas e Gestão da Educação Superior da Universidade Federal do Ceará. 2019.

[5] FERnANDES, G. J. Gestão do Conhecimento: o que é, importância e como aplicar. 2019. Disponível em: https://fia.com.br/blog/gestao-do-conhecimento/. Acesso em: Jul de 2020. 
[6] FERNANDES, M. C. et al. Universidade e a extensão universitária: a visão dos moradores das comunidades circunvizinhas. Educ. rev. Belo Horizonte, v. 28, n. 4, p. 169-194, dez. 2012. Disponível em: http://www.scielo.br/scielo.php?script=sci_arttext\&pid=S0102-

46982012000400007\&lng=pt\&nrm=iso. Acesso em: jul. 2020. https://doi.org/10.1590/S0102-46982012000400007.

[7] FERREIRA, P. A. 0 avanço da tecnologia e as transformações na sociedade. 2017. Disponível em: https://noticias.portaldaindustria.com.br/artigos/paulo-afonsoferreira/o-avanco-da-tecnologia-e-as-transformacoes-na-sociedade/. Acesso em: jul. de 2020.

[8] FÓRUM DE PRÓ-REITORES DE EXTENSÃO DAS UNIVERSIDADES PÚBLICAS BRASILEIRAS - FORPROEX, 2010, Belo Horizonte. Extensão Universitária: organização e sistematização. Belo Horizonte: COOPMED, 2010.

[9] Avaliação da Extensão Universitária: práticas e discussões da comissão permanente de avaliação da extensão. 2013.

[10] GADOTTI, M. Extensão Universitária: Para quê? Disponível em: https://www.paulofreire.org/images/pdfs/Extens\%C3\%A3o_Universit\%C3\%A1ria__Moacir_Gadotti_fevereiro_2017.pdf> Acesso em 9 de jul de 2020.

[11] GIL, A. C. Métodos e técnicas de pesquisa em educação ambiental. In: PHILIPPI JUNIOR., A; PELICIONI, M.C.F. (Org.). Educação ambiental e sustentabilidade. Barueri: Manole, 2005. p. 577-598.

[12] MÁXIMO, W. Agência Brasil. Economia do Brasil encolherá 5,2\% por causa de pandemia, prevê Cepal. Brasília. 2020. Disponível em: https://agenciabrasil.ebc.com.br/economia/noticia/2020-04/economia-do-brasilencolhera-52-por-causa-de-pandemia-preve-cepal > Acesso em 11 de jul de 2020.

[13] MC CARTHY; JEROME. Marketing. Rio de Janeiro: Campus, 1982.

[14] MORAIS, J. A Pandemia nos tornou mais reféns da tecnologia, avalia o filósofo João de Moraes. [12 de maio de 2020]. Tele.Síntese. Entrevista concedida a Flávia Gonçalves. Disponível em: http://www.telesintese.com.br/a-pandemia-nostornou-mais-refens-da-tecnologia-avalia-o-filosofo-joao-de-moraes/. Acesso em: jul. de 2020 .

[15] NOGUEIRA, M. das D. P. (org). Políticas de Extensão Universitária Brasileira. Belo Horizonte: UFMG. 2005.

[16] OLIVEIRA, J. N. de. YouTube como fonte de conhecimento: Análise sobre como o YouTube auxilia na construção da vida profissional e na desintermediação das práticas em grupos de camada popular. 40ํㅡㄹ Congresso Brasileiro de Ciências da Comunicação Curitiba - PR. 2017.

[17] OLIVEIRA, L. M. et al. 0 reflexo das tecnologias na construção e desconstrução da sociedade. Revista do Centro do Ciências Naturais e Exatas - UFSM, Santa Maria, V. 19, n. 1, jan.- abr. 2015, p.114-120.

[18] PTDRS - PLANO TERRITORIAL DE DESENVOLVIMENTO RURAL SUSTENTÁVEL. Conselho de Desenvolvimento Sustentável do Território de Irecê, p. 10, 2010. Disponível em: http://sit.mda.gov.br/download/ptdrs/ptdrs_qua_territorio050.pdf > Acesso em 11 de jul de 2020. 
[19] RFB - RECEITA FEDERAL DO BRASIL. 2020. Disponível em: https://datasebrae.com.br/totaldeempresas/> Acesso em 11 de jul. de 2020.

[20] ROCHA, Ana Karine L. T.; DAVID, Ana Celeste Cruz ; AYALA, Mariela Pinto ; CAMPOS, Maria de Fatima Hanaque. DIÁLOGO DE EXPERIÊNCIAS SOBRE EXTENSÃo UNIVERSITÁRIA E TECNOLOGIA SOCIAL. Raízes \& Rumos, v. 02, p. 116-155, 2014.

[21] SANTOS, B.S. A universidade no século XXI: para uma reforma democrática e emancipatória da Universidade. São Paulo: Cortez, 2004.

[22] SEBRAE - Serviço Brasileiro de Apoio às Micro e Pequenas Empresas. Medidas Oficiais para o Enfrentamento do Covid-19. 2020. Disponível em: https://respostas.sebrae.com.br/wp-content/uploads/2020/04/medidas-oficiais-xcovid-19-7.pdf> Acesso em 11 de jul de 2020.

[23] SERrano, M. S. M. Grupo de pesquisa em extensão popular. Conceitos de Extensão universitária: um diálogo com Paulo Freire. 2013.

[24] SILVA, A. C. A.; CORREIA, Anna Elizabeth G. C.; LIMA, Izabel F. o conhecimento e as tecnologias na sociedade da informação. Revista Interamericana de Bibliotecología. Ene.-Jun. 2010, vol. 33, no. 1, p. 213-239.

[25] SOUZA, B. Marketing Digital 2.0: como sair na frente da concorrência. 2012.

[26] TAKASE, S. Impacto da Revolução Tecnológica na Dimensão Humana da Informação. 2007. Dissertação em (Mestrado em Ciência da Informação) Departamento de Ciência da Informação e Documentação da Universidade de Brasília, Brasília.

[27] THIOLLENT, M. Metodologia da pesquisa-Ação. 18. ed. São Paulo: Cortez, 2011.

[28] TORRES, C. A bíblia do marketing digital. 1a ed. São Paulo: Novatec, 2009.

[29] TOZONI-REIS, M.F.C. A pesquisa-ação-participativa e a educação ambiental: uma parceria construída pela identificação teórica e metodológica. In:TOZONI-REIS, M.F.C. (Org.). A Pesquisa-ação-participativa em educação ambiental: reflexões teóricas. São Paulo: Annablume, 2007. p. 121-161. 


\section{Capítulo 2}

Gestão na educação profissional e seus reflexos para a melhoria dos resultados no ensino e na aprendizagem

Ithany Felipe Alcântara da Silva Ana Karine Loula Torres Rocha 


\section{INTRODUÇÃO}

Assim como a economia, a política e o campo social, a educação vem passando por mudanças em que todos são desafiados a encontrar novos modelos para novas situações onde os processos de gestão têm buscado a transformação de atuação das pessoas envolvidas de forma interativa e recíproca, a partir de uma óptica aberta, democrática e sistêmica.

As exigências para lidar com as novas demandas relacionadas à formação e qualificação passaram a ser cada vez maiores. Tais fatores conduziram a uma redefinição da qualificação, tanto em relação à base de conhecimentos, quanto às possibilidades formativas. Neste novo contexto houve um aumento das exigências profissionais, levando e/ou forçando as pessoas a buscarem, cada vez mais, uma maior qualificação.

Libâneo (2001, p. 349) concebe a gestão como sendo o conjunto de todas as atividades de coordenação e de acompanhamento do trabalho das pessoas, envolvendo o cumprimento das atribuições de cada membro da equipe, a realização do trabalho em equipe, a manutenção do clima de trabalho e a avaliação de desempenho.

Para Luck (2007, p. 109),

O que se preconiza é uma nova óptica de organização e direção de instituições, tendo em mente a sua transformação e de seus processos, mediante a transformação de atuação, de pessoas e de instituições de forma interativa e recíproca, a partir de uma perspectiva aberta, democrática e sistêmica.

Caminhamos para modelos de gestão mais complexos e diferenciados, mais descentralizados, mais integrados, horizontalizados e flexíveis, baseados em grupos e equipes de trabalho que se aproximam do modelo de organização aberta e de uma abordagem contingencial, uma vez que esta abordagem afirma não ser possível estabelecer uma única forma de gerir as organizações onde cada situação requer um tipo de ação específica e não há planos, estruturas, estilos de liderança ou controles únicos padronizados em todas as situações vivenciadas pela organização. As organizações precisam identificar as diferentes formas de se estruturarem e se organizarem para as diferentes situações que vão sendo apresentadas.

A palavra qualidade tem sido amplamente utilizada relacionada em geral à eficácia, eficiência, produtividade e a competitividade, objetivando atender as 
expectativas dos sujeitos, em um mercado cada vez mais diversificado e em constante atualização. Segundo (GIL, 2002), (Raquel Mattos, 2013) essas discussões não deixaram de influenciar o campo da gestão educacional nas reformas dos anos de 1990. 0 tema qualidade ganha ênfase no marco da reforma educacional, sendo um dos princípios orientadores da gestão escolar. Libâneo (2001, p. 54) aponta que,

A educação de qualidade é aquela que promove para todos o domínio de conhecimentos e o desenvolvimento de capacidades cognitivas, operativas e sociais necessários ao atendimento de necessidades individuais e sociais dos alunos, à inserção no mundo do trabalho, a constituição da cidadania, tendo em vista a construção de uma sociedade mais justa e igualitária.

Para promover essa educação de qualidade este autor afirma que,

[...] 0 que as escolas precisam buscar, de fato, é a qualidade cognitiva das experiências de aprendizagem dos alunos [...] em consonância com as exigências sociais e educacionais contemporâneas significa prestar atenção nos conteúdos que estão sendo ensinados, na afetividade desses conteúdos para a vida prática. (LIBÂNEO, 2001, p. 56 - 57).

Para Novaes (2007), passou-se a atribuir à educação a responsabilidade fundamental por promover formação profissional e prover a demanda requerida pelo novo e complexo mundo do trabalho. Ainda para Novaes (2007), a relação entre educação e formação profissional adquiriu centralidade nas políticas governamentais dos países dos diversos continentes, assumindo o encargo por promover a formação de profissionais.

Neste sentido e refletindo sobre os Índices de Desenvolvimento da Educação Básica IDEB 2017 de uma forma geral e em especial referente aos dados do Território de Identidade de Irecê - TII ${ }^{1}$, que em sua totalidade estão muito abaixo da média esperada

\footnotetext{
1 Território: o conceito adotado é "um espaço geograficamente definido, geralmente contínuo, compreendendo a cidade e o campo, caracterizado por critérios multidimensionais - tais como o ambiente, a economia, a sociedade, a cultura, a política e as instituições -, e uma população com grupos sociais relativamente distintos, que se relacionam interna e externamente por meio de processos específicos, onde se pode distinguir um ou mais elementos que indicam identidade e coesão social, cultural e territorial." (BRASIL. Ministério do Desenvolvimento Agrário. Programa Nacional de Desenvolvimento Sustentável de Territórios Rurais. Referências para o apoio ao desenvolvimento territorial. Brasília, 2004. p. 04-05). Considera-se Território de Identidade o agrupamento identitário municipal formado de acordo com critérios sociais, culturais, econômicos e geográficos, que é reconhecido pela sua população como espaço historicamente construído ao qual pertencem com identidade de amplia as possibilidades de coesão social e territorial. 0 Território de Identidade de Irecê (TII) está localizado no semiárido baiano e é
} 
como podemos observar no gráfico a seguir:

Gráfico: 1. Índice de Desenvolvimento da Educação Básica

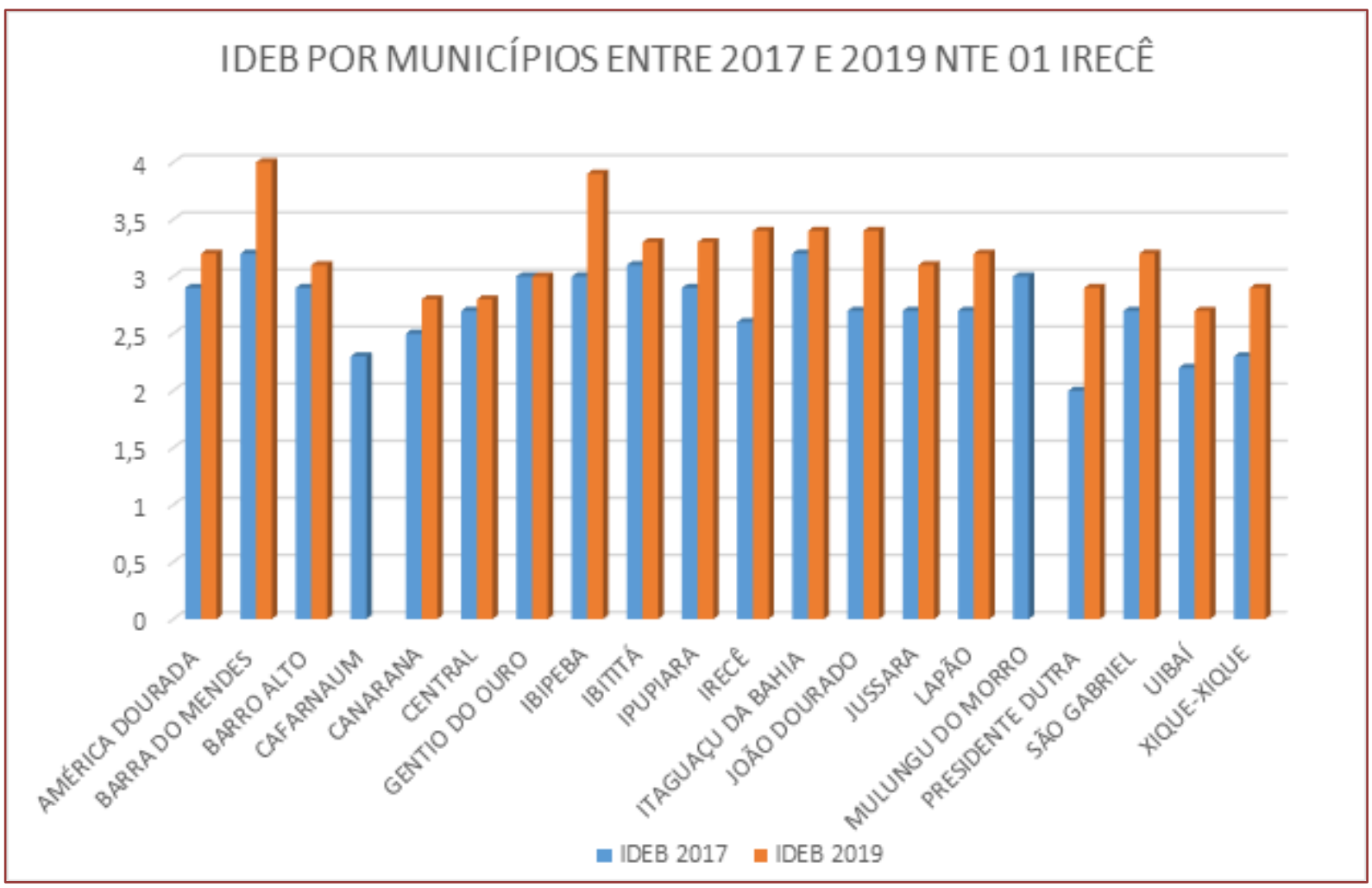

FONTE: INEP - Instituto Nacional de Estudos e Pesquisas Educacionais Anísio Teixeira - IDEB Resultados.

É possível apontar que uma das razões para estes resultados apresentados no gráfico esteja relacionada, dentre outros fatores, à insuficiente ou má formação dos gestores educacionais. De acordo com Santos (2008, p. 10),

A formação dos gestores continuará mostrando um descompasso enorme com a gestão para a modernidade, em razão também de os referidos cursos manterem-se resistentes a mudanças, repetindo a formação do passado, quando a educação não ganhara o destaque que assume hoje no contexto das atividades sociais e profissionais, exigindo repensar o ato de educar. Acresce-se ainda que as mudanças que vêm ocorrendo no campo da gestão empresarial não podem ser ignoradas, tendo em vista a precariedade de estudos e das pesquisas educacionais e a necessidade de preparar pessoas capazes de entender o novo significado que assumem a gestão educacional e a escola dos sistemas e das escolas respectivamente.

formado por vinte municípios - América Dourada, Barro Alto, Barra do Mendes, Cafarnaum, Canarana, Central, Gentio do Ouro, Ibipeba, Ibititá, Ipupiara, Irecê, Itaguaçu da Bahia, João Dourado, Jussara, Lapão, Mulungu do Morro, Presidente Dutra, São Gabriel, Uibaí e Xique-Xique. (BAHIA. Secretaria do Planejamento do Estado da Bahia. Caracterização: Território Irecê. Salvador, 2012). 
Percebemos a necessidade de ter à frente da gestão pública educacional um gestor e uma equipe qualificada, com formação específica sobre a gestão educacional. Diante desse contexto desenvolvemos este estudo que se configura como um estudo preliminar sobre Gestão na Educação Profissional no Estado da Bahia, e definimos enquanto objetivo deste trabalho, analisar as estratégias e processos da gestão escolar implementadas no Centro Técnico de Educação Profissional do Território de Irecê CETEP/Irecê, no período de 2014 a 2019 e sua contribuição para melhoria dos resultados no ensino e na aprendizagem identificando as estratégias, processos e metodologias da gestão escolar nos âmbitos administrativos, pedagógico e relacional através de uma pesquisa.

Quanto aos aspectos metodológicos definimos quanto à natureza como uma pesquisa descritiva e exploratória de abordagem qualitativa, que é definida como um tipo de investigação voltada para os aspectos subjetivos que não podem ser traduzidos em números ou em estatísticas, a fim de compreender as atitudes, motivações e comportamentos de determinado grupo de pessoas (GIL, 2008); (FONSECA, 2002).

Buscamos com este estudo evidenciar a importância que o gestor educacional tem dentro do ambiente educativo trazendo as especificidades inerentes ao seu trabalho, mostrar quais estratégias e processos a gestão escolar pode implementar para que uma instituição de ensino se torne uma referência e em que medida essas estratégias e processos podem contribuir para a melhoria dos resultados no ensino e na aprendizagem.

Este estudo está vinculado às linhas de pesquisa "Educação Profissional, Juventudes e Tecnologias" e "Gestão, Políticas Educacionais e Gestão de Territórios" do Grupo de Pesquisa GENTTES/ CNPq: Grupo de Pesquisa em Trabalho, Educação, Gestão e Tecnologias, da Universidade do Estado da Bahia - UNEB / DCHT, Campus XVI Irecê/BA. Foi apoiado pelo Edital 023/2019, referente ao aviso no 026/2019, publicado no D.O.E. de 20/03/2019, que trata de processo seletivo de projetos de extensão e concessão de bolsas de monitoria de extensão da Universidade do Estado da Bahia UNEB. 


\section{CONTEXTUALIZANDO A EDUCACÃO PROFISSIONAL NA BAHIA: CEEP'S E CETEP'S} Segundo dados do Ministério da Educação (MEC), no Brasil, entre os anos de 2007 e 2013, houve um grande avanço no número de matrículas de educação profissional, tanto no setor público, que sai de 393.008, em 2007, e passa para 749.675, em 2013, quanto no setor privado, que sai de 387.154, em 2007, e passa para 691.376, em 2013.

De acordo com dados divulgados pelo Departamento Intersindical de Estatística e Estudos Socioeconômicos (2014), intitulado Educação Profissional da Bahia: Geração, Gênero e Etnia, o número de matrículas de educação profissional técnica cresceu, significativamente, entre os anos de 2007 e 2013, passando de 22.337 para 88.767, considerando os sistemas Federal, Estadual, Municipal e Privada.

A organização da educação profissional na Bahia, segue a lógica da territorialização como uma estratégia de interiorização e inclusão dos estudantes e trabalhadores, fazendo parte da política de divisão territorial do Estado. A expansão por Territórios de Identidade é baseada na criação de Centros Territoriais de Educação Profissional; com essa estratégia, os jovens e trabalhadores são preparados para trabalhar em seus municípios, em seus territórios, não precisando mais migrar em busca de oportunidades em outras regiões.

O Território de Identidade de Irecê (TII) está localizado no semiárido baiano, é formado por vinte municípios e segundo dados da Secretaria do Planejamento (BAHIA, 2012), o TII apresenta características essencialmente rurais onde $69 \%$ dos estabelecimentos são constituídos de pequenas propriedades rurais e a produção agrícola contribui para a economia do território, especialmente a produção familiar. Sua população é extremamente carente, onde 59\% das famílias são beneficiárias do principal programa de transferência de renda do Brasil, o Bolsa Família.

Segundo (Santos, 2001) a educação profissional tem como objetivos não só a formação de técnicos de nível médio, mas a qualificação, a requalificação, a reprofissionalização para trabalhadores com qualquer escolaridade, a atualização tecnológica permanente e a habilitação nos níveis médio e superior. Sendo assim tal modalidade de educação deve levar ao permanente desenvolvimento de aptidões para a vida produtiva.

No Brasil, a Lei de Diretrizes e Bases da Educação Nacional (LDB), de 1996 no seu capítulo V, diz que, 
Art. 39. A educação profissional, integrada às diferentes formas de educação, ao trabalho, à ciência e à tecnologia, conduz ao permanente desenvolvimento de aptidões para a vida produtiva. Parágrafo único. 0 aluno matriculado ou egresso do ensino fundamental, médio e superior, bem como o trabalhador em geral, jovem ou adulto, contará com a possibilidade de acesso à educação profissional. Art. 40. A educação profissional será desenvolvida em articulação com o ensino regular ou por diferentes estratégias de educação continuada, em instituições especializadas ou no ambiente de trabalho. Art. 41. 0 conhecimento adquirido na educação profissional, inclusive no trabalho, poderá ser objeto de avaliação, reconhecimento e certificação para prosseguimento ou conclusão de estudos. Parágrafo único. [...] Art. 42. As escolas técnicas e profissionais, além dos seus cursos regulares, oferecerão cursos especiais, abertos à comunidade, condicionada a matrícula à capacidade de aproveitamento e não necessariamente ao nível de escolaridade. (LDB, 1964)

A política de educação profissional no estado da Bahia foi formulada em sintonia com as diretrizes de desenvolvimento para o Estado, definidas no Plano Plurianual2, sendo construídas na perspectiva do planejamento governamental de médio e longo prazo, em consonância com as projeções de demandas socioeconômicas, sendo consideradas como área estratégica no projeto de desenvolvimento do estado. Segundo (MANFREDI, 2002).

A educação profissional pode ser apontada como um campo de disputa e de negociação entre os diferentes segmentos e grupos que compõem uma sociedade, desvelando a dimensão histórico-política das reformas de ensino, das concepções, dos projetos e das práticas formativas (MANFREDI, 2002).

0 decreto $\mathrm{n}^{\mathrm{o}}$ 11.355/2008 (BAHIA, 2008), de 4 de dezembro de 2008, criou os Centros Estaduais e os Centros Territoriais de Educação Profissional. A função dos Centros Estaduais estava relacionada ao atendimento das demandas estratégicas para o desenvolvimento socioeconômico e ambiental do estado e se caracterizam pela oferta de educação profissional com ênfase nas seguintes modalidades:

a) Formação inicial e continuada;

b) Educação profissional e técnica de nível médio, nas variantes integrada e subsequente;

c) Educação profissional integrada à educação de jovens e adultos, chamado de

\footnotetext{
20 PPA é um instrumento previsto no art. 165 da Constituição Federal destinado a organizar e viabilizar a ação pública, com vistas a cumprir os fundamentos e os objetivos da República. Por meio dele, é declarado o conjunto das políticas públicas do governo para um período de 4 anos e os caminhos trilhados para viabilizar as metas previstas. Disponível em:

http://www.planejamento.gov.br/servicos/faq/planejamento-governamental/plano-plurianualppa/oque-eacute-o-ppa. Acesso em: 25 fev. 2020.
} 
Programa Nacional de Integração da Educação Profissional com a Educação Básica na Modalidade de Educação de Jovens e Adultos (PROEJA);

d) Educação profissional à distância (semipresencial);

e) Educação tecnológica.

A função dos Centros Territoriais de Educação Profissional estava vinculada à satisfação das demandas consideradas relevantes nos Territórios de Identidade do estado da Bahia e caracterizavam-se pela oferta de educação profissional, no âmbito de cada Território, nas mesmas modalidades, exceto a educação tecnológica.

Neste cenário surge o Centro Técnico de Educação Profissional do Território de Irecê - CETEP/Irecê, uma instituição de ensino técnico e pública do governo do Estado da Bahia, que apresentou índices educacionais acima da média na SAEB e no período de 2014 a 2019 houve uma maior procura de matrículas, chegando a superar a média de todo o Território Identidade de Irecê.

O CETEP implantou um modelo de gestão escolar inovadora, que fez tal instituição, em um curto espaço de tempo, se tornar recentemente um referencial em educação para todo Território Identidade de Irecê. Diante deste contexto buscamos compreender quais estratégias e processos da gestão escolar foram implementados no Centro Técnico de Educação Profissional do Território de Irecê - CETEP/Irecê para que se tornasse uma referência no Território de Identidade de Irecê-Ba (TII) e em que medida essas estratégias e processos contribuíram para a melhoria dos resultados no ensino e na aprendizagem.

Este levantamento nos proporcionou analisar como funciona essa instituição e a partir dessa compreensão desenvolver uma base referencial de procedimentos, estratégias, processos e de material didático que apoie os gestores e instituições de ensino a buscarem melhorias nos resultados no ensino e na aprendizagem de forma eficiente e com qualidade promovendo assim uma formação mais integral, além do desenvolvimento da educação do TII.

\section{GESTÃO EDUCACIONAL: O GESTOR ESCOLAR NO DESEMPENHO DAS FUNÇÕES}

Podemos definir a Gestão educacional como a instituição de processos técnicos e pedagógicos que propicie uma regulamentação e desenvolvimento de estratégias 
efetivas para ampliar a eficácia dos processos dentro da instituição e, assim, promover uma consistente melhoria nas áreas administrativas, financeiras, pedagógicas, interpessoais e de ensino e aprendizagem. Os gestores escolares são responsáveis por um conjunto de atividades que envolvem a gestão administrativa-financeira, gestão de pessoas, gestão de materiais e infraestrutura e a gestão pedagógica.

O gestor educacional é visto pelos demais profissionais da educação como aquele responsável também pelas dimensões pedagógicas de relações humanas construídas e, dinamicamente, manifestadas nas mais diversas possibilidades de um contexto escolar. Assim, há uma forte tendência que situa a versão profissional do gestor escolar a um administrador de "mil funções". Santos (2008, p. 14) reflete sobre esta questão, apontando que,

Um dilema, até o momento, parece-nos insolúvel: as atribuições previstas nas normas estatutárias e regimentais, embora exijam do gestor escolar maior ênfase no trabalho pedagógico (atividade-fim), acabam dando margem, na prática à predominância do administrativo- burocrático ( atividade-meio) por força das tarefas rotineiras; registros de vida escolar do aluno; prontuário dos professores e funcionários, relatórios de medidas e ações propostas pelas secretarias da educação e todo tipo de levantamentos estatísticos. Acresce que para tantas tarefas, regulares ou extras, na grande maioria das escolas públicas, a infraestrutura material, financeira e humana é bastante precária.

Como percebemos no dilema apresentado por (Santos, 2008) as funções estatutárias e regimentais do gestor às vezes lhe fogem por conta da sobrecargas das “atividades-meio" tecnoburocrática porém não podemos ver a gestão educacional e seu gestor somente no desenvolvimento da prática tecnoburocrática como vem acontecendo a muito tempo, temos que tencionar o gestor para uma nova administração/gestão educacional na qual o seus agentes além do desenvolvimento do papel técnico institucional compreenda a dimensão política da sua função, segundo (Praias, 1994),

Desafia-se na administração escolar a capacidade de superar uma ação meramente técnica (administração de normas, pessoal e material), efetivando-se uma função política há muito desgastada pela atuação meramente executora das decisões de gabinete dos tecnoburocratas. A novidade da proposta reside em exigir do administrador-educador que ele compreenda a dimensão política de sua ação administrativa, que se respalda na ação colegiada, rompendo com a rotina alienada do mundo impessoal e racionalizada da burocracia, que permeia, ou melhor, cimenta a dominação das organizações modernas. Em síntese, propõe-se recuperar com vigência o papel do diretor-educador na liderança do processo educativo (PRAIAS, 1994, p. 60). 
Assim, assumindo essa dimensão política da sua função que se respalda na ação colegiada que vai além do desempenho das funções técnicas o gestor educacional deve se basear no conceito de gestão democrática que envolve, além da participação dos professores, também a participação da equipe pedagógica, funcionários, pais, alunos e comunidade escolar para assim ter um desempenho satisfatório do desenvolvimento educacional da instituição de ensino.

O Gestor educacional hoje tem que se respaldar na gestão democrática para o desempenho da sua função, para entendermos melhor a Gestão Democrática a Constituição Federal de 1998 no art.o 206 parágrafo VI traz os primeiros amparos legais para a prática da Gestão Democrática:

Art. 206. 0 ensino será ministrado com base nos seguintes princípios: I - Igualdade de condições para o acesso e permanência na escola;

II - Liberdade de aprender, ensinar, pesquisar e divulgar o pensamento, a arte e o saber;

III - pluralismo de ideias e de concepções pedagógicas, e coexistência de instituições públicas e privadas de ensino;

IV - Gratuidade do ensino público em estabelecimentos oficiais;

V - Valorização dos profissionais da educação escolar, garantidos, na forma da lei, planos de carreira, com ingresso exclusivamente por concurso público de provas e títulos, aos das redes públicas; (Redação dada pela EC n. $53 / 2006)$

VI - Gestão democrática do ensino público, na forma da lei;

VII - garantia de padrão de qualidade.

VIII - piso salarial profissional nacional para os profissionais da educação escolar pública, nos termos da lei federal. (Incluído pela EC n. 53/2006).

Como podemos observar na na Constituição Federal de 1988, art.ํ VI o ensino público será pauta na Gestão Democrática tendo sido esse o primeiro amparo legal, contudo mais tarde na Lei de Diretrizes de Bases da Educação Brasileira (LDB 9394/96) apresenta os princípios que norteiam a gestão democrática na educação:

Art. 14. Os sistemas de ensino definirão as normas da gestão democrática do ensino público na educação básica, de acordo com as suas peculiaridades e conforme os seguintes princípios:

I - Participação dos profissionais da educação na elaboração do projeto pedagógico da escola;

II - Participação das comunidades escolar e local em conselhos escolares ou equivalentes.

A partir do que foi acima apresentado na gestão democrática todos que compõem o sistema de ensino e a comunidade escolar participam das decisões administrativasfinanceiras e construções pedagógicas das instituições de ensino como a exemplo da elaboração e cumprimento do Projeto Político Pedagógico da instituição e atividades que 
impactam no desenvolvimento educacional dos estudantes, tal participação nesses processos acarretam em uma transparência de ações e atos em todos os aspectos e tudo isso segundo (Brasil, 2004) "possibilita à comunidade escolar e local a aquisição de conhecimentos, saberes, ideias e sonhos, num processo de aprender, inventar, criar, dialogar, construir, transformar e ensinar."

A Gestão democrática tem um papel social para mudar o atual cenário e transformar nossas relações com as escolas e instituições educativas; esse modelo de gestão abre um espaço de escuta e participação proporcionando o exercício da democracia e da autonomia contrapondo às políticas neoliberais, como afirma Dourado, 2006:

[...] a gestão democrática é entendida como processo de aprendizado e de luta política que não se circunscreve aos limites da prática educativa, mas vislumbra, nas especificidades dessa prática social e de sua relativa autonomia, a possibilidade de criação de canais de efetiva participação e de aprendizado do "jogo" democrático e, consequentemente, do repensar das estruturas de poder autoritário que permeiam as relações sociais e, no seio dessas, as práticas educativas (DOURADO, 2006, P.79).

Para este autor a gestão democrática não é só um processo de aprendizado, mas sim de luta política quando abrimos canais de participação e (re)construção das estruturas e espaços de decisões políticas, econômicas, sociais e culturais.

\section{METODOLOGIA, RESULTADOS E DISCUSSÃO}

É importante destacar que este é um estudo que se configura como preliminar sobre gestão na educação profissional no Estado da Bahia e seus reflexos na melhoria dos processos de ensino e aprendizagem, onde definimos etapas a serem executadas e previsão de conclusão no formato de trabalho de conclusão de curso.

No decorrer deste processo refletirmos e buscamos a melhor forma de desenvolver a pesquisa visando à construção e execução de métodos que pudessem responder ao problema de pesquisa definido para este trabalho: Quais estratégias $e$ processos da gestão escolar foram implementados no Centro Técnico de Educação Profissional do Território de Irecê - CETEP/Irecê, para que se tornasse uma referência no Território de Identidade de Irecê-Ba (TII)? E em que medida essas estratégias e processos contribuíram para a melhoria dos resultados no ensino e na aprendizagem? 
Para responder ao problema de pesquisa utilizamos quanto à natureza a pesquisa descritiva e exploratória de abordagem qualitativa, que é definida como um tipo de investigação voltada para os aspectos subjetivos que não podem ser traduzidos em números ou em estatísticas, a fim de compreender as atitudes, motivações e comportamentos de determinado grupo de pessoas, ou seja, utiliza-se de uma investigação qualitativa de uma determinada questão (GIL, 2008); (FONSECA, 2002). Preocupa-se, portanto, com aspectos da realidade que não podem ser quantificados, centrando-se na compreensão e explicação da dinâmica das relações sociais (FONSECA, 2002).

Minayo (2009) amplia esta visão quando nos diz que a pesquisa qualitativa,

Trabalha com o universo dos significados, dos motivos, das aspirações, das crenças, dos valores e das atitudes. Esse conjunto de fenômenos humanos é entendido aqui como parte da realidade social, pois o ser humano se distingue não só por agir, mas por pensar sobre o que faz e por interpretar suas ações dentro e a partir da realidade vivida e partilhada com seus semelhantes (MINAYO, 2009, p. 21).

Tendo a pesquisa se desencadeado por uma abordagem qualitativa de natureza descritiva e exploratória optou-se por utilizar o estudo de caso como método de pesquisa, pois o mesmo se aproxima do objetivo.

O estudo de caso pode ser definido como o estudo de um determinado objeto, instituição, programa, sistema educativo ou uma unidade social (FONSECA, 2002). Como método de pesquisa propõe conhecer seu objeto de estudo de uma maneira muito aprofundada a fim de elucidar coisa antes não vistas de um objeto que se diz único, busca identificar o que é essencial e característico para aquele objeto que, conforme (YIN 2010, p.39), “o estudo de caso é uma investigação empírica que investiga um fenômeno contemporâneo em profundidade e em seu contexto de vida real, especialmente quando os limites entre o fenômeno e o contexto são claramente evidentes.". A partir disso o pesquisador manifesta em sua ótica os resultados obtidos nos estudos sobre determinado objeto tal como ele percebe.

Os resultados obtidos no estudo de caso devem ser provenientes da convergência ou da divergência das observações obtidas de diferentes procedimentos. Dessa maneira é que se torna possível conferir validade ao estudo, evitando que ele fique subordinado à subjetividade do pesquisador (GIL, 2002, p. 140). No processo de identificação e 
compreensão dos dados e informações passamos por análises, reflexões e interpretações, sempre buscando a melhor maneira de decodificar as informações coletadas para não cair na falsa certeza de ter conclusões próprias e precipitadas do pesquisador como expõe GIL (2002).

\begin{abstract}
Um dos maiores problemas na interpretação dos dados no estudo de caso deve-se à falsa sensação de certeza que o próprio pesquisador pode ter sobre suas conclusões. Embora esse problema possa aparecer em qualquer outro tipo de pesquisa, é muito mais comum no estudo de caso (GIL, 2002, p. 141).
\end{abstract}

Tendo esse cuidado, como explica Gil (2002) é necessário ordenar e encontrar a melhor maneira de trabalhar os dados obtidos fazendo assim, após sua tabulação e organização, a melhor relação entre a pesquisa e os resultados obtidos. De acordo com Yin (2005), "[...] a análise dos dados consiste em examinar, categorizar, classificar em tabelas, testar, ou do contrário, recombinar evidências quantitativas e qualitativas para tratar as proposições iniciais de um estudo" de modo a conseguir interligar suas informações obtidas a o interesse do trabalho.

O estudo de caso é uma verdadeira construção e desconstrução constantes até identificar a melhor maneira de utilizar os dados e informações obtidas na coleta de maneira que tais informações representam o objeto de pesquisa verdadeiramente.

A partir da problemática elencada até aqui e dos dados e informações apresentadas foi possível perceber através da observação a grande importância de compreendermos sobre a gestão educacional e sua relação com a qualidade dos resultados obtidos.

Este trabalho tem, como lócus de pesquisa, o CETEP/Irecê, e, como participantes do estudo os sujeitos envolvidos na gestão administrativa e pedagógica da referida instituição no período de 2014 a 2019, totalizando 14 sujeitos, definidos por adesão (a opção de participação foi livre aos que têm interesse em colaborar). Esta escolha deu-se em função do aumento de matrículas e dos índices positivos do SAEB nas datas supracitadas, chegando a superar a média de todo o TII.

Utilizamos diversos dispositivos de levantamentos de informações, tais como análise documental, imagens, observação, questionário, entrevista, utilização de ferramentas como google forms, dentre outros, a fim de conseguirmos realizar uma coleta de informações que possibilitasse chegar às respostas dos questionamentos 
elencados até aqui, buscando dados confiáveis e relevantes para este estudo.

Um dos fatores apontados nos dados obtidos no decorrer da pesquisa é que parte da precariedade do ensino estava ligada às ações e estratégias dos gestores educacionais como foi exposto na $2^{\mathrm{o}}$ etapa da semana pedagógica da rede estadual ocorrido em agosto de 2018 no Instituto Anísio Teixeira IAT/SEC-BA. Tais gestores e suas equipes enfrentam problemas pela inadequada e/ou insuficiente capacitação e formação continuada.

Considera-se que a formação do gestor escolar, ou a falta da mesma, tem implicações positivas ou negativas na organização do trabalho pedagógico e administrativo das escolas, podendo influenciar nos seus resultados. Segundo Lück (2000, p. 29),

\begin{abstract}
Não se pode esperar mais que os dirigentes escolares aprendam em serviço, pelo ensaio e erro, sobre como resolver conflitos e atuar convenientemente em situações de tensão, como desenvolver trabalho em equipe, como monitorar resultados, como planejar e implementar o projeto político pedagógico da escola, como promover a integração escola-comunidade, como criar novas alternativas de gestão, como realizar negociações, como mobilizar e manter mobilizados atores na realização das ações educacionais, como manter um processo de comunicação e diálogo abertos, como estabelecer unidade na diversidade, como planejar e coordenar reuniões eficazes, como articular interesses diferentes, etc. Os resultados da ineficácia dessa ação são tão sérios em termos individuais, organizacionais e sociais, que não se pode continuar com essa prática. A responsabilidade educacional exige profissionalismo. (LÜCK 2000, p. 29).
\end{abstract}

Assim, diante deste cenário, foi possível perceber através de visitas técnicas e observação a necessidade de desenvolver capacitação e formação continuada aos gestores educacionais tendo em vista a melhoria do ensino e aprendizagem, pois de acordo com Libâneo (2008), o funcionamento da escola interfere nos resultados dos alunos e, por consequência, na qualidade da escola. Assim alguns pontos devem ser considerados e observados pelo gestor escolar no exercício de sua função, que deve ser pautado na busca da qualidade do ensino/aprendizagem.

Devemos observar as experiências que deram certo, investigar tal prática, tornando-a referência para outros contextos e colaborando na construção de novos caminhos. Atualmente há uma carência por formação continuada para gestores e um número reduzido de possibilidade formativas a exemplo da Escola de Gestores, do MEC, que teve início em 2005 e a Capacitação a Distância para Gestores Escolares PROGESTÃo criado pelo Conselho dos Secretários de Estado da Educação - CONSED a partir de 2001. 
Esta pesquisa encontra-se em fase de desenvolvimento com previsão de conclusão na defesa de monografia da graduação prevista para acontecer em 2022.1, portanto, os resultados aqui apresentados são ainda parciais e preliminares.

\section{CONCLUSÕES}

Consideramos que para exercer a função de gestor escolar é necessário bem mais que "ser escolhido pela comunidade escolar", isso significa dizermos que, para estar à frente da gestão de uma instituição educativa são necessários conhecimentos específicos como lidar com recursos financeiros, planejamento estratégico e conhecimentos tecnológicos e administrativos, além é claro, pedagógicos. Segundo Libâneo (2004),

\footnotetext{
O diretor de escola é o dirigente e principal responsável pela escola, tem a visão de conjunto, articula e integra os vários setores (setor administrativo, setor pedagógico, secretaria, serviços gerais, relacionamento com a comunidade, etc.). [...] as funções do diretor são, predominantemente, gestoras e administrativas, entendendo-se, todavia, que elas têm conotação pedagógica, uma vez que se referem a uma instituição e a um projeto educativo e existem em função do campo educativo (p. 217).
}

A partir de informações obtidas sobre a importância da gestão escolar para a melhoria do ensino, aprendizagem e qualidade na educação, buscamos com esta pesquisa evidenciar a importância que o gestor educacional tem dentro do ambiente educativo trazendo as especificidades inerentes ao seu trabalho e buscando mostrar quais estratégias e processos a gestão escolar pode implementar para que uma instituição de ensino se torne uma referência e em que medida essas estratégias e processos podem contribuir para a melhoria dos resultados no ensino e na aprendizagem.

A partir desta análise problematizamos a partir da discussão sobre a formação do gestor, pois as instituições de ensino necessitam ter a frente da gestão administrativa, pedagógica e relacional um gestor e sua equipe preparados para lidar com as adversidades do ambiente escolar, analisar as condições observadas em espaços profissionais com base nos conhecimentos adquiridos e sendo capazes de propor soluções para os problemas identificadas. 


\section{REFERÊNCIAS}

[1] Alves-Mazzotti, Alda Judith. Usos e abusos dos estudos de caso. Cad. Pesquisa. [online]. 2006, vol.36, n.129, pp.637-651. ISSN 0100-1574. Disponível em: < http://ref.scielo.org/7wscsg> acessado em: 22 de julho de 2019.

[2] BRASIL. Constituição (1988). Constituição da República Federativa do Brasil. Brasília, DF: Senado Federal: Centro Gráfico, 1988. (acesso em: 13 de julho de 2020)

[3] BRASIL. Ministério da Educação. Secretaria de Educação Básica. Programa Nacional de Fortalecimento dos Conselhos Escolares. Gestão da educação escolar. Brasília: UnB/ CEAD, 2004. (acesso em: 13 de julho de 2020)

[4] BRASIL. Lei de Diretrizes e Bases da Educação Nacional, LDB. Lei 9394, 20 de dezembro de 1996.

[5] DOURADO, Luiz F. A escolha dos dirigentes escolares: políticas e gestão da educação no Brasil. In: FERREIRA, Naura S. Carapeto (Org.). Gestão democrática da educação: atuais tendências, novos desafios. 5a ed. São Paulo: Cortez, 2006.

[6] Fonseca, Metodologia da Pesquisa Científica. PPGEA, v.1, 2002. Disponível em:<http://www.ia.ufrrj.br/ppgea/conteudo/conteudo20121/1SF/Sandra/apostilaMetodologia.pd f> acessado em: 19 de julho de 2019.

[7] Gil, Antônio Carlos, 1946 Como elaborar projetos de pesquisa. 4. Ed. - São Paulo: Atlas, 2002.

[8] Gil, Raquel Mattos, 0 Papel do Gestor Escolar na Melhoria da Qualidade da Educação. Cad. PDE. V 1, 2013 Disponível em:

<http://www.gestaoescolar.diaadia.pr.gov.br/modules/conteudo/conteudo.php?conte udo=1631> acessado em: 19 de julho de 2019 .

[9] LIBÂNEO, J. C. Organização e Gestão da Escola. Goiânia: Alternativa, 2001.

[10] LIBÂNEO J. C. Educação Escolar: Políticas, Estruturas e Organização. São Paulo. Cortez. 2008.

[11] LÜCK, H. A Escola Participativa: o trabalho do gestor escolar. 2a ed Rio de Janeiro: DP \& A Editora, 1998.

[12] LÜCK, H. A Perspectivas da Gestão Escolar e Implicações quanto à Formação de seus Gestores. In: Em Aberto, $n^{\circ} 72$ (Gestão Escolar e Formação de Gestores), jun. de 2000 .

[13] LUCK, Heloísa. Gestão Educacional: uma questão paradigmática. 3. ed. Petrópolis: Vozes, 2007.

[14] MANFREDI, Silvia Maria. Educação profissional no Brasil. São Paulo: Cortez, 2002.

[15] MENEZES, Ebenezer Takuno de SANTOS, Thais Helena dos. Verbete educação profissional. Dicionário Interativo da Educação Brasileira - Educabrasil. São Paulo: Midiamix, 2001. Disponível em: https://www.educabrasil.com.br/educacaoprofissional/. Acesso em: 25 de fev. 2020.

[16] ROCHA, Ana Karine Loula Torres. Educação Profissional na Bahia: Representações sociais dos egressos no Território de Identidade de Irecê. 2019. 262 f. Tese (Doutorado) - Curso de Pós-graduação em Educação e Contemporaneidade, Departamento de Educação, Universidade do Estado da Bahia, Salvador, 2019. 
[17] PRAIS, Maria de Lourdes Melo. Administração Colegiada na Escola Pública. 3a ed. Campinas - SP: Papires, 1994.

[18] SANTOS, Clóvis Roberto dos. A gestão educacional e escolar para a modernidade. São Paulo: Cengage Learning, 2008.

[19] VIANA, A. L. Abordagens Metodológicas em Políticas Públicas. Caderno de pesquisa. Unicamp, São Paulo, n.05, 1988. 


\section{Capítulo 3}

A influência de variáveis manipuláveis em testes de usabilidade na realização de atividades computacionais envolvidas no desenvolvimento de tecnologia assistiva de baixo custo

Paulo André da Rocha Perris

Fernando da Fonseca de Souza 


\section{INFORMAÇÕES GERAIS}

A tecnologia assistiva (TA) tem contribuído para a reabilitação de pessoas com necessidades específicas (PNE), fornecendo acessibilidade a locais e recursos, a fim de facilitar sua vida cotidiana. Entre esses recursos, estão os computacionais, que visam atualizar o conhecimento das PNE, bem como capacitá-las ou obter requalificação profissional por meio de dispositivos de acessibilidade e ambientes de educação a distância [Cook \& Polgar, 2014; Kurt, 2018].

As tecnologias educacionais, desenvolvidas para a educação a distância, oferecem várias oportunidades para um processo de aprendizagem mais eficaz [Martins at all, 2015]. Devido à evolução dessas tecnologias, cada pessoa, com ou sem necessidade específica, pode se tornar um estudante, capaz de se qualificar individualmente e ter suas próprias responsabilidades no processo educacional, além de controlar o objetivo que deseja alcançar. [Alsobhi, Nawaz \& Harjinder, 2015; Laabidi, at all., 2014].

A escolha de usar um cenário em ambientes de educação a distância deve-se à sua adequação ao nosso objeto metodológico. Quanto às atividades a serem realizadas, delimita e abrange todo o escopo tecnológico (teste e validação de software, dispositivo apontador, software auxiliar assistivo) que foi utilizado e desenvolvido pelos pesquisadores para comprovar suas alegações [Mackenzie, p. 160, 2012].

\section{ARTIGOS RELACIONADOS}

No escopo do desenvolvimento de software assistivo, muitos pesquisadores buscam desenvolver aplicativos que visam testar dispositivos apontadores auxiliares como uma alternativa ao software Fitts [Bandeira \& Zucatelli, 2016]. Outros se preocupam com a calibração do dispositivo, para maior precisão em seu posicionamento [Biswas e Langdon, 2015], mas poucos desenvolvem software que trabalha em conjunto com dispositivos apontadores e promove total acessibilidade aos recursos computacionais para PNE.

As tecnologias analisadas neste tópico têm como objetivo auxiliar pessoas com graves limitações de mobilidade motora. No entanto, existem particularidades em suas composições, desenvolvimento, modos de uso e aplicabilidade que serão aprimoradas ou descartadas neste artigo, pois são apontadas como falhas ou ineficazes por si só.

A grande maioria dos softwares desenvolvidos na TA se preocupa com a usabilidade dos dispositivos e detectores frontais no rosto do usuário (webcam, Kinect, 
sensores infravermelhos, Nintendo wii). Fatos como a variação da luz e a distância do usuário aos sensores frontais influenciam diretamente no desempenho dos dispositivos apontadores assistivos (hardwares), pois tais variáveis dificultam a localização natural de qualquer dispositivo, implicando diretamente em sua usabilidade de ponteiro [Azmi, Nawaf \& Majed, 2009].

Todos os dispositivos apontadores encontrados na literatura são frontais. Três usam óculos como suporte para os sensores e possuem sensores de comunicação de dados na parte superior do monitor para detectar o rosto do usuário. Além disso, o foco dos dispositivos está sempre em pontos específicos do rosto do usuário (olhos, nariz, boca).

As dificuldades relatadas pelos pesquisadores na literatura são as seguintes:

I. Controle do brilho da luz ambiente do ambiente para uma perfeita leitura dos movimentos pelas câmeras;

II. Distância limitada para uma leitura perfeita dos movimentos e gestos da câmera ou sensores;

III. Controle de vários objetos presentes na imagem detectada pela câmera (análise do objeto apontador e descarte de objetos secundários) e;

IV. Obstáculos que surgem na frente dos sensores para capturar os movimentos e gestos do usuário durante o uso.

Todos esses fatos levantam as seguintes questões de pesquisa: A - Poderia existir uma solução em tecnologia assistiva de baixo custo que resolva esses problemas e se demonstre eficaz? B - A aplicação de uma variável manipulada poderá melhorar a eficácia de sua usabilidade?

\section{METODOLOGIAS}

Dos três métodos comuns para a realização de pesquisas em interação humano computador - IHC, utilizamos o método observacional e o método experimental para desenvolver o hardware e o software utilizados nos experimentos deste artigo. 


\subsection{DISPOSITIVO APONTADOR}

A partir da análise dos problemas encontrados no mapeamento sistemático, os pesquisadores decidiram desenvolver um dispositivo apontador próprio, criando o hardware auxiliar assistivo - HAA.

O HAA foi desenvolvido com as mesmas funcionalidades mecânicas que um mouse convencional, mas mais limpo e direcionado ao problema de acessibilidade para pessoas com necessidades específicas, especificamente tetraplegia. Ficará posicionado no apoio de cabeça do usuário na cadeira de rodas e irá capturar os movimentos da cabeça através do led e do sensor óptico incorporado ao HAA. Ele irá capturar os movimentos da cabeça do usuário, da mesma forma que o mouse captura em um mousepad, onde nesse caso a cabeça do usuário, no ponto do osso occipital, é o mousepad HAA.

Figura 1 - Posicionamento do AAH no encosto da cabeça do usuário. (Imagem Dreamstime, direito adquirido pelo autor, adaptada pelo autor

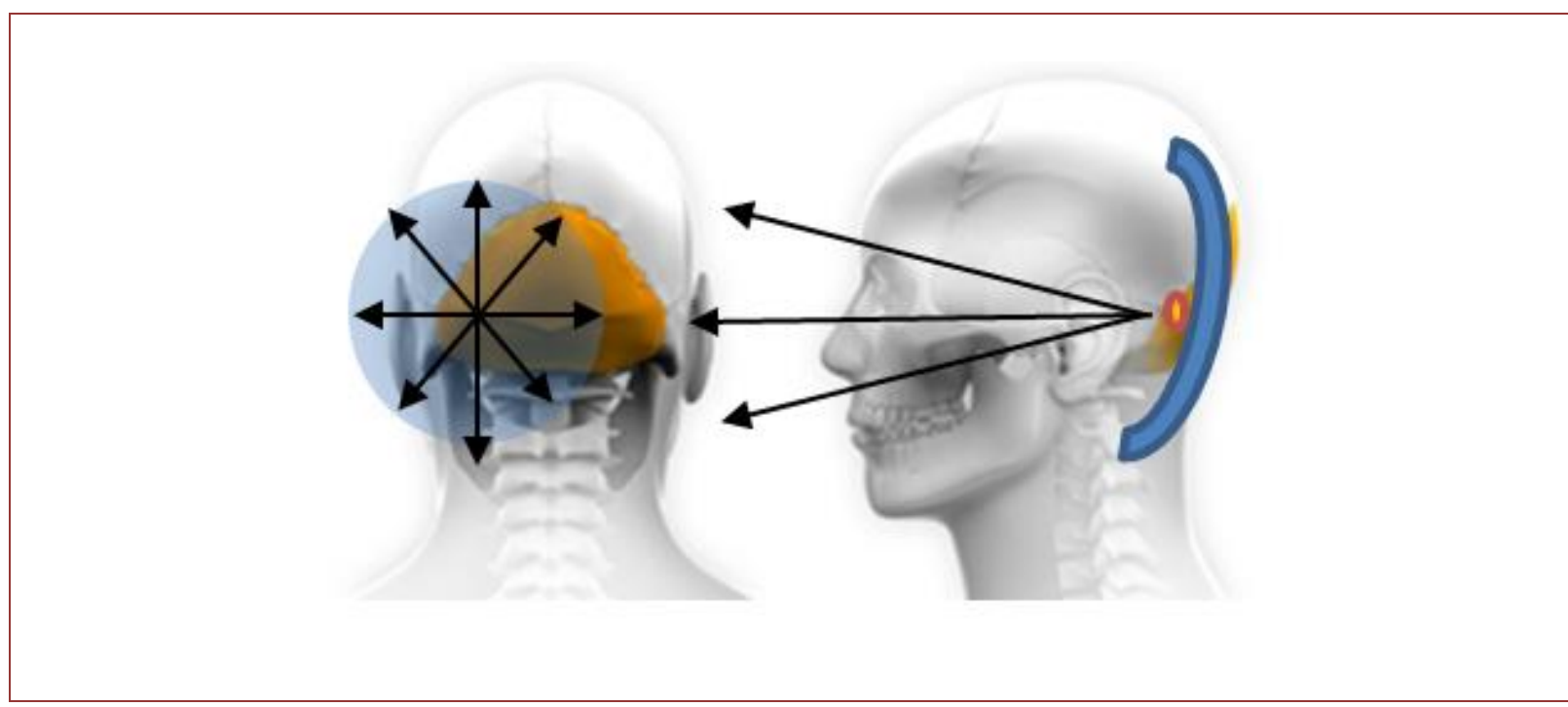

O primeiro protótipo do HAA consiste em um led, dois resistores (51ohms e $51 \mathrm{~K}$ ), dois capacitores (100nF e 10mF), um botão (estado normalmente aberto), um circuito integrado M16183 (sensor óptico), uma lente de ampliação de prisma para foco e um cabo USB para alimentar o dispositivo. Todos os componentes necessários são facilmente encontrados em lojas especializadas e seu custo total não excede cinquenta reais. 
Figura 2 - Protótipo funcional do HAA

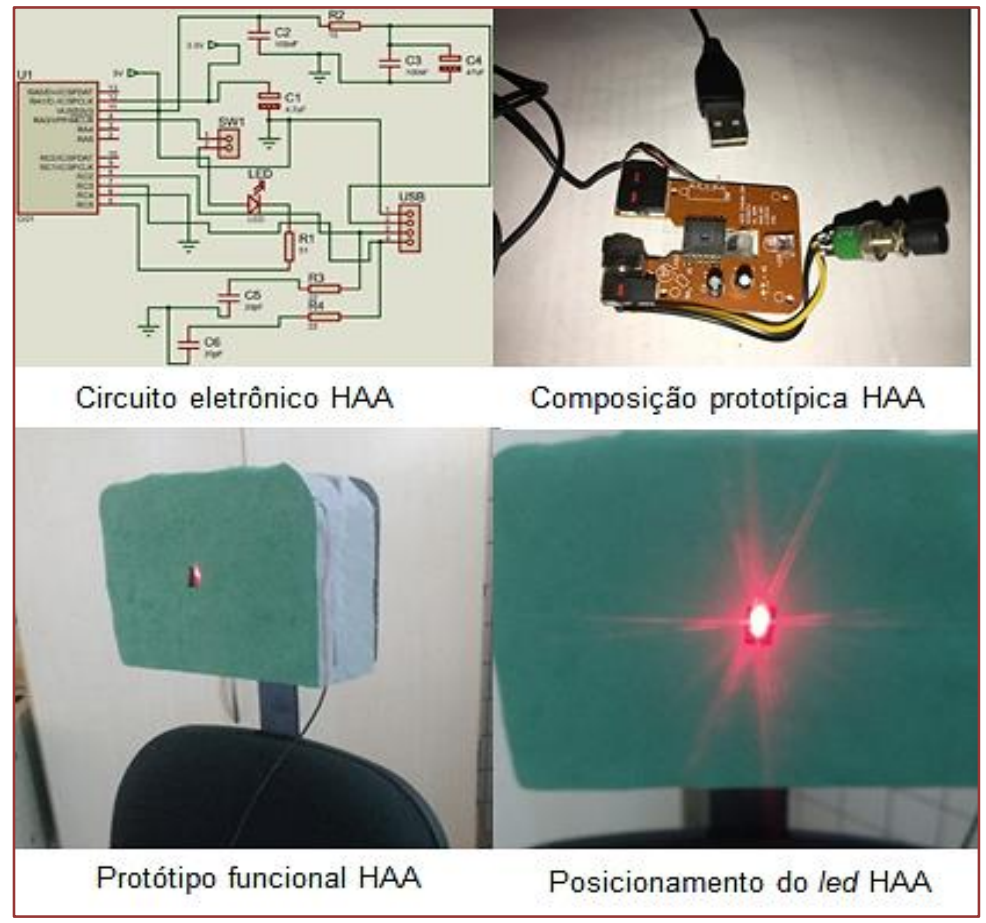

Fonte: Dados do autor, 2020.

\subsection{O SOFTWARE AUXILIAR ASSISTIVO}

Foi observado a necessidade de um software que auxiliasse na realização das atividades computacionais a serem propostas aos participantes. Elaborou-se, por meio do roteiro das atividades, uma análise de todas as necessidades que o usuário teria para acessar os recursos computacionais disponíveis para executar atividades básicas em um computador.

Pontos importantes foram abordados para o desenvolvimento do software. Entre eles, a independência do PNE na escolha de quais aplicativos devem estar disponíveis para ele. A possibilidade de trocar aplicativos também foi um ponto observado pelos pesquisadores. Foram realizadas entrevistas com os alunos da disciplina Interação Humano-Computador - IHC e um usuário de cadeira de rodas com lesão medular C6, sendo este o principal consultor e avaliador do conjunto (hardware e software) desenvolvido nesta pesquisa.

O software auxiliar assistivo (SAA) funciona monitorando todas as ações do AAH, principalmente a duração do clique, que pressionado por alguns segundos (3 e não mais do que 5 segundos) abre uma janela trazendo os principais programas para o usuário. É possível aos PNE configurá-lo a qualquer momento. O SAA foi desenvolvido seguindo as 
regras do IHC (ícones grandes, fáceis de observar e muito intuitivos), como mostra a Figura.

Decidiu-se chamar, com a criação do HAA e do SAA, de Sistema Auxiliar Assistivo Modular - SAAM, desenvolvido com o objetivo de fornecer acesso à PNE a recursos computacionais, com a finalidade de realizar atividades computacionais específicas.

Para comprovar a eficácia do SAAM, aos participantes da pesquisa foram solicitados realizarem as seguintes atividades computacionais: acessar o navegador, digitar um endereço de site específico, acessar o ambiente virtual de aprendizagem (AVA), assistir uma aula gravada em vídeo, responder a um exercício temático do ambiente e finalize a sessão.

Figura 3 - 1- Ícone do SAA para adicionar aplicativos, 2- Aplicativos já adicionados ao SAA, 3- Slots vazios do SAA.

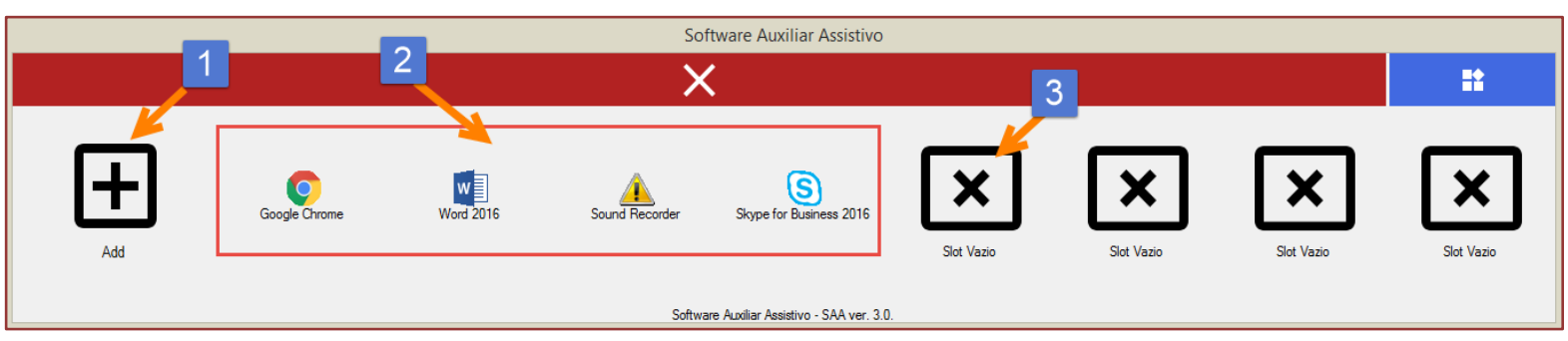

Fonte: Dados do autor, 2020.

Para medir a eficácia do IAAS, foram computados os tempos de execução dos participantes que executaram as atividades. Erros encontrados durante as atividades também foram pontuados. E, no final, foi emitido um questionário que pontuava o nível de satisfação do usuário com o IAAS e coletava sugestões para possíveis melhorias.

\section{ATIVIDADES E RESULTADOS}

\subsection{ESTATÍSTICA}

Os resultados estatísticos de duas sessões de testes de acessibilidade e resolução de atividades de 16 participantes comprovaram a eficácia do uso conjunto de HAA e SAA (SAAM). Tal prova foi baseada no P-Value encontrado [Soukoreff \& MacKenzie, 2004], que apresentou resultados estatísticos de 28,2\% (valor significativo) em um intervalo de confiança de 95\% (Figura). 
Figura 4 - Relatório do software Minitab, obtendo um valor $p$ de 0,282 em um intervalo de confiança de $95 \%$.

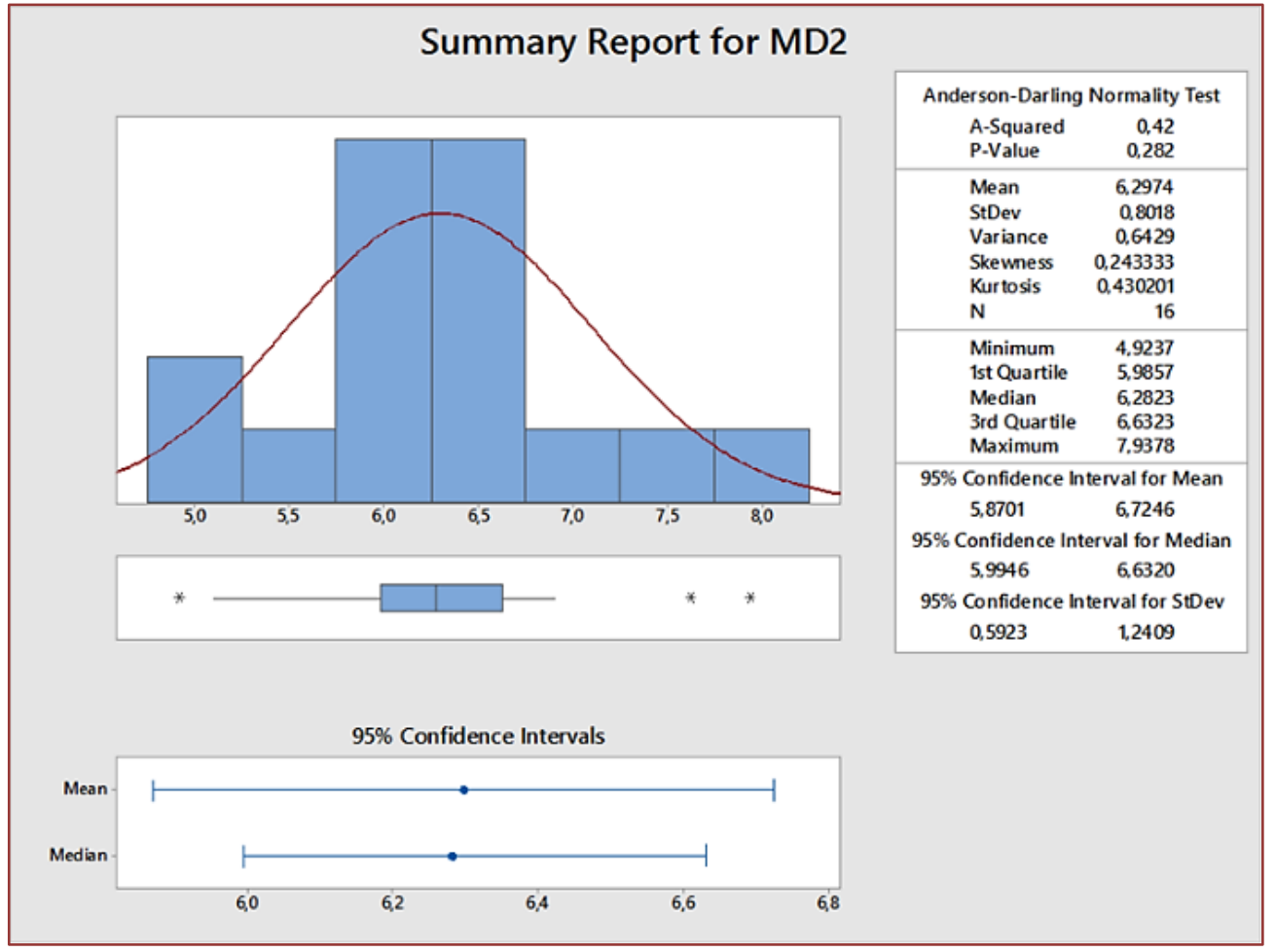

Fonte: Dados do autor, 2020.

\subsection{AVALIAÇÃO DA USABILIDADE}

Somente para dois dos usuários de teste, não foi possível observar a evolução da usabilidade com o SAAM (usuários US3 e US8) (Figura 5). Relataram em suas entrevistas que tiveram cansaço e desconforto em relação à rotina das atividades propostas para serem realizadas com o SAAM. Eles alegaram não estar muito dispostos a fazer as atividades.

Para o usuário 6 (US6) do teste, no entanto, foi possível observar uma evolução acentuada. Ele começou com valores de transmissão de dados abaixo de um mouse convencional no primeiro dia de teste, sendo apenas o oitavo para concluir os testes no primeiro dia e evoluindo. ser o terceiro a terminar as experiências no segundo dia de testes.

Os usuários US4 e US15 iniciaram a atividade com valores de transmissão de dados superiores ao uso de um mouse convencional. Eles continuaram a evoluir na usabilidade do SAAM no segundo dia de teste. Atribuímos isso à sua experiência em controlar melhor os movimentos da cabeça (um consultor e o outro o pesquisador), mantendo o foco no experimento e a motivação para desenvolver novas tecnologias. 
Figura 5 - Minitab Line Plot sobre avaliação de usabilidade.

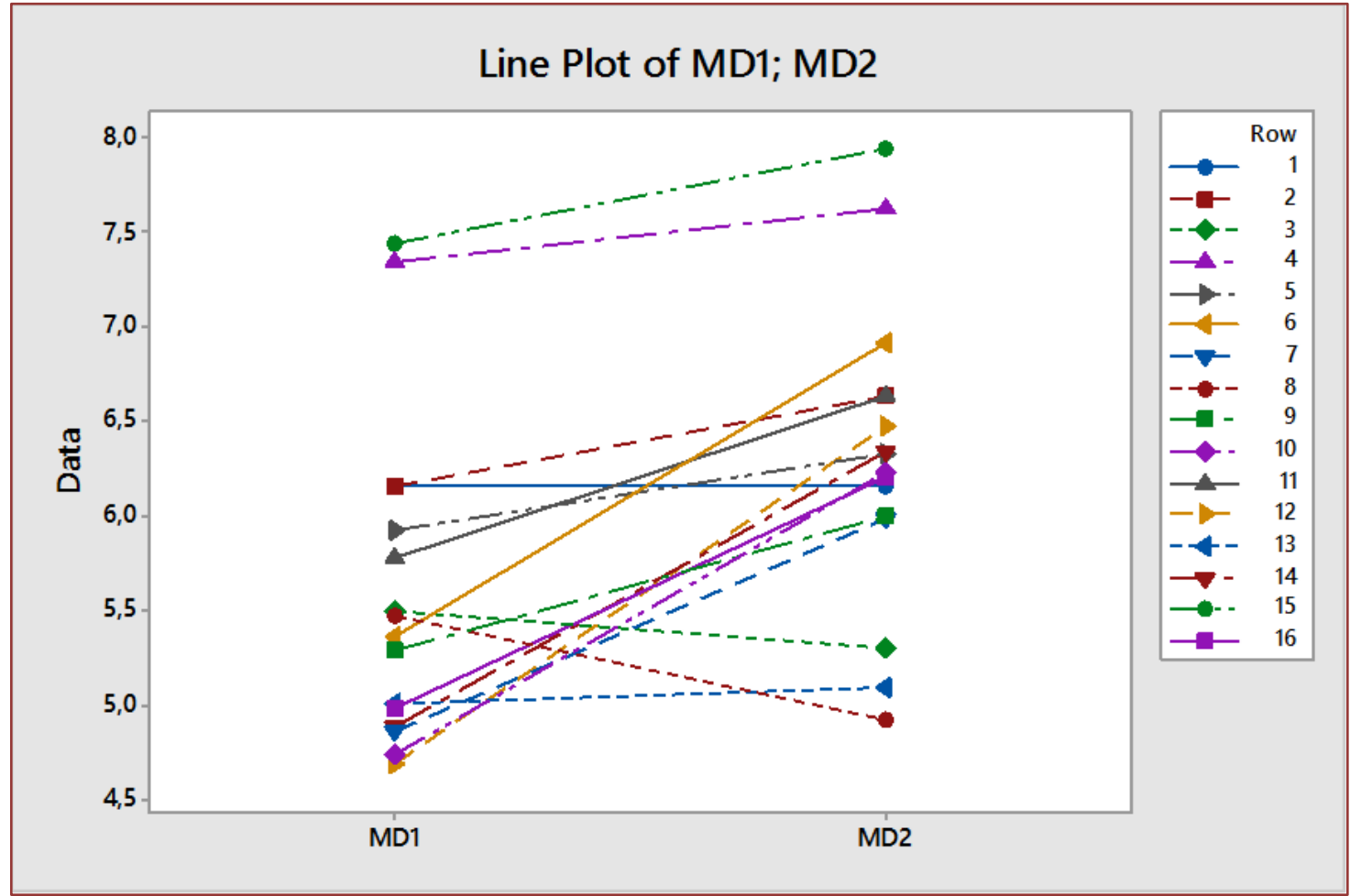

Fonte: Dados do autor, 2020.

\subsection{ATIVIDADE PRÁTICA EM UM AMBIENTE REAL}

Para medir a eficácia do IAAS, foi proposto a todos os usuários a realização de atividades em um AVA. As etapas da atividade proposta foram: acessar o AVA, encontrar o módulo do curso, assistir a um vídeo sobre um tópico proposto, responder a um questionário com várias opções sobre o tópico mostrado no vídeo, enviar suas respostas pelo AVA, terminar a sessão e sair da plataforma.

Neste ponto da pesquisa, decidimos utilizar o método observacional e experimental, pois segundo Mackenzie [p. 130 e 131, 2012] "Na condução de pesquisas empíricas em IHC, é essencial observar seres humanos interagindo com computadores ou com alguma tecnologia incorporada a computadores". Foi utilizada a variável manipulada "penalidade por erro" como uma das duas variáveis no experimento controlado para fins de validação.

Durante as atividades, cada etapa foi cronometrada. Cada erro do usuário (clique fora do destino) foi adicionado como uma penalidade de 0,30 s em seu tempo total de atividade. Os resultados dos dois dias de experiências qualitativas são mostrados na Tabela 1 e na Tabela 2. 
Tabela 1 - Dados do primeiro dia de atividades

\begin{tabular}{|c|c|c|c|c|c|c|c|c|}
\hline \multicolumn{9}{|c|}{ Painel de atividades do primeiro dia } \\
\hline Usuário & Login & $\begin{array}{l}\text { Localizar o } \\
\text { módulo no AVA }\end{array}$ & Vídeo & $\begin{array}{c}\text { Ler e } \\
\text { responder ao } \\
\text { exercício }\end{array}$ & $\begin{array}{c}\text { Enviar a } \\
\text { atividade no } \\
\text { AVA }\end{array}$ & $\begin{array}{l}\text { Total sem } \\
\text { contabilizar } \\
\text { erros }\end{array}$ & Erros & $\begin{array}{c}\text { Tempo total } \\
\text { contabilizando } \\
\text { erros }\end{array}$ \\
\hline US1 & 6,22 & 2,23 & 8,60 & 24,33 & 0,11 & 41,49 & 6 & 43,29 \\
\hline US2 & 5,41 & 1,47 & 8,21 & 26,51 & 0,15 & 41,75 & 18 & 47,15 \\
\hline US3 & 9,18 & 0,55 & 8,50 & 28,01 & 0,15 & 46,39 & 12 & 49,99 \\
\hline US4 & 6,55 & 0,24 & 8,16 & 22,15 & 0,13 & 37,23 & 6 & 39,03 \\
\hline US5 & 7,49 & 1,01 & 8,20 & 21,19 & 0,24 & 38,13 & 6 & 39,93 \\
\hline US6 & 8,02 & 0,33 & 8,15 & 20,55 & 0,15 & 37,20 & 12 & 40,80 \\
\hline US7 & 6,48 & 0,29 & 8,20 & 19,38 & 0,11 & 34,46 & 6 & 36,26 \\
\hline US8 & 11,02 & 0,41 & 8,33 & 24,55 & 0,13 & 44,44 & 24 & 51,64 \\
\hline US9 & 6,50 & 0,27 & 8,10 & 26,17 & 0,14 & 41,18 & 30 & 50,18 \\
\hline US10 & 5,32 & 0,57 & 8,22 & 29,52 & 0,12 & 43,75 & 0 & 43,75 \\
\hline US11 & 6,53 & 1,12 & 8,22 & 20,49 & 0,12 & 36,48 & 6 & 38,28 \\
\hline US12 & 8,06 & 0,52 & 8,17 & 26,43 & 0,15 & 43,33 & 24 & 50,53 \\
\hline US13 & 10,08 & 1,03 & 8,13 & 23,51 & 0,14 & 42,89 & 12 & 46,49 \\
\hline US14 & 5,44 & 0,45 & 8,09 & 21,16 & 0,10 & 35,24 & 6 & 37,04 \\
\hline US15 & 8,30 & 0,55 & 8,16 & 24,50 & 0,12 & 41,63 & 18 & 47,03 \\
\hline US16 & 5,59 & 0,51 & 8,20 & 28,17 & 0,14 & 42,61 & 0 & 42,61 \\
\hline
\end{tabular}

Fonte: Dados do autor, 2020.

Todos os participantes ficaram surpresos com as penalidades de tempo adicionais por erros em suas atividades. Eles alegaram que não imaginavam que pequenos erros pudessem adicionar muito ao tempo final do experimento.

Foi perguntado aos participantes que, se tivessem cometido menos erros, eles teriam terminado suas atividades em menos tempo. Eles foram unânimes em dizer que sim. Mesmo com essa afirmação, aos participantes não foram impostas novas regras sobre erros no segundo dia de teste.

Tabela 2 - Segundo dia de atividades.

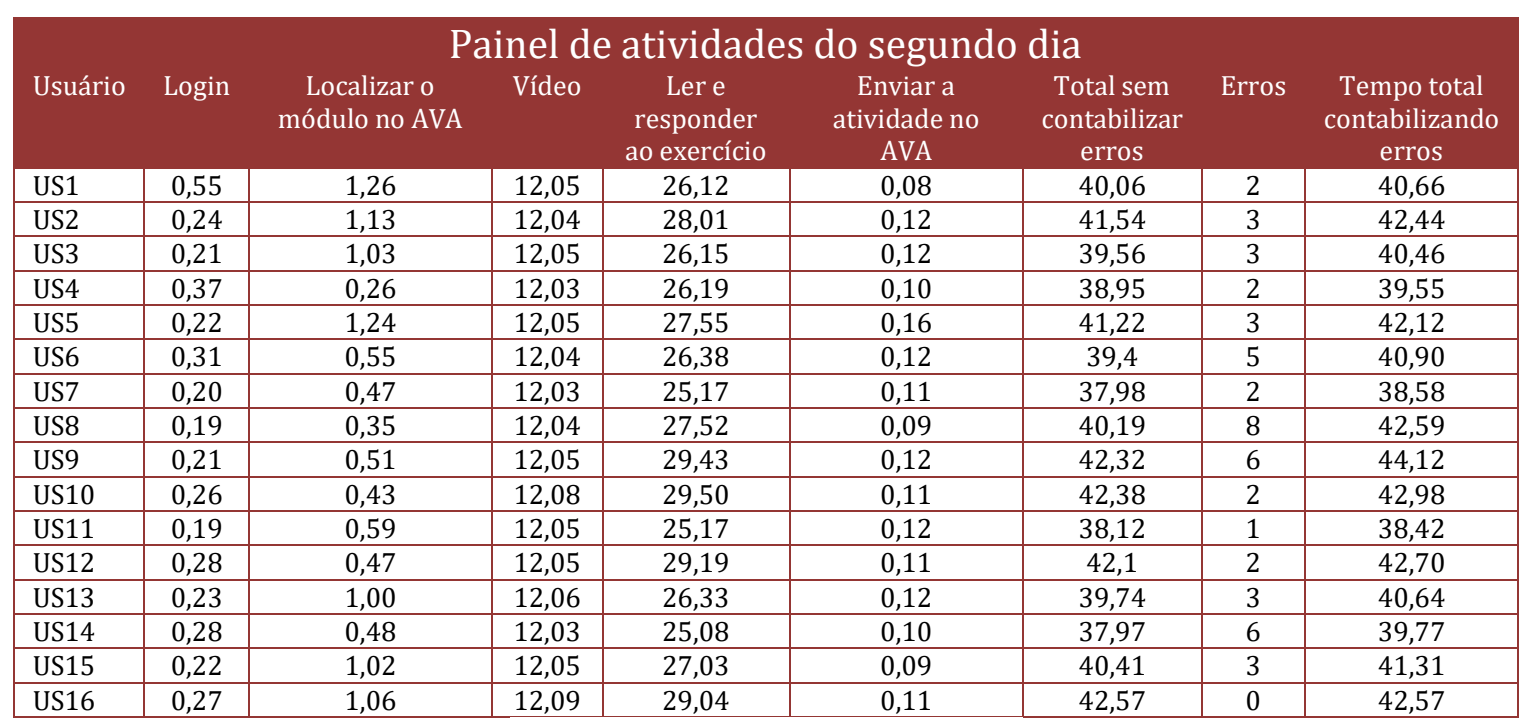

Fonte: Dados do autor, 2020.

Foi possível observar nos resultados do segundo dia de atividades que algumas das características do navegador escolhido para os testes (Ex.: salvar o login e a senha), foram aprimoradas. Todos os participantes que tiveram problemas com logins e senhas 
longos os resolveram clicando no botão OK para efetuar login, sem a necessidade de digitar essas informações novamente usando o teclado virtual e o SAAM.

O Quadro 1 mostra o resultado da análise comparativa das atividades realizadas pelos participantes, evidenciando que os participantes US8 e US9 tiveram um aumento maior no tempo por terem cometido mais erros (Quadro 1).

Quadro 1 - Tempo sem contabilizar e contabilizando erros de atividades no primeiro dia.

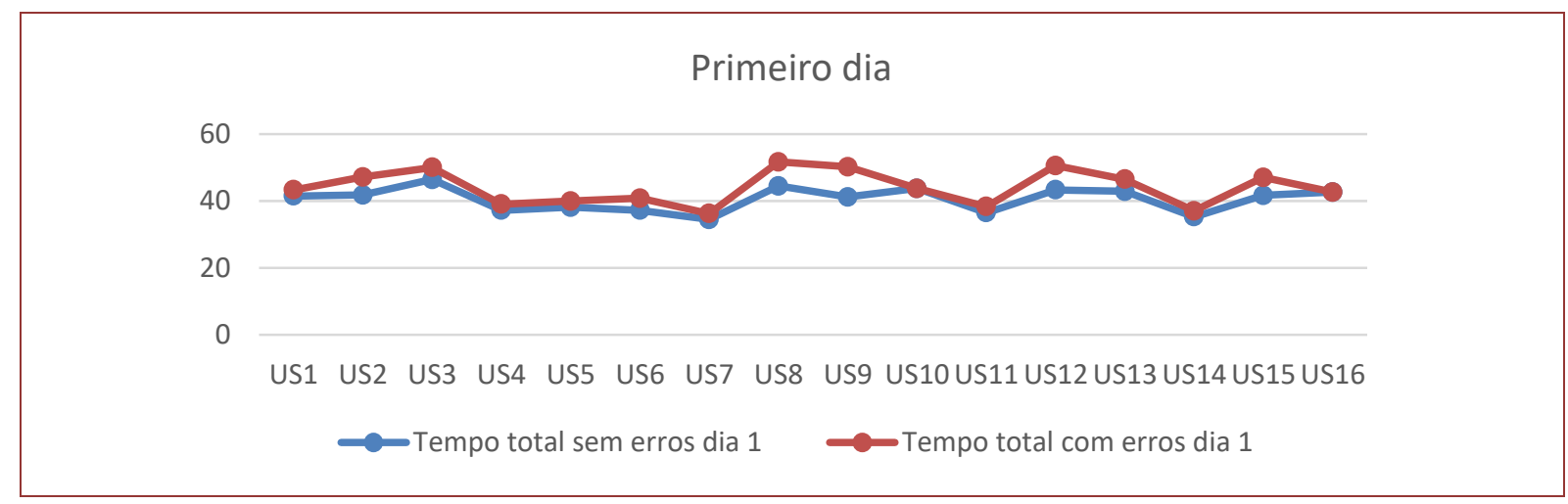

Fonte: Dados do autor, 2020.

No segundo dia de atividades, todos os participantes tiveram o cuidado de não cometer erros ou cometer o menor número possível de erros. Questionados sobre o cuidado de não cometer erros, eles responderam que não gostariam de ser penalizados com tempo extra para as atividades. Observou-se com isso que o tempo de realização das atividades aumentou naturalmente (Quadro 2).

A diferença entre o número de erros no primeiro dia de atividades e no segundo dia de atividades é graficamente visível (Quadro 3), mostrando apenas o participante US10 cometendo mais erros no segundo dia do que no primeiro.

Quadro 2 - Tempo sem contabilizar e contabilizando erros de atividades no segundo dia.

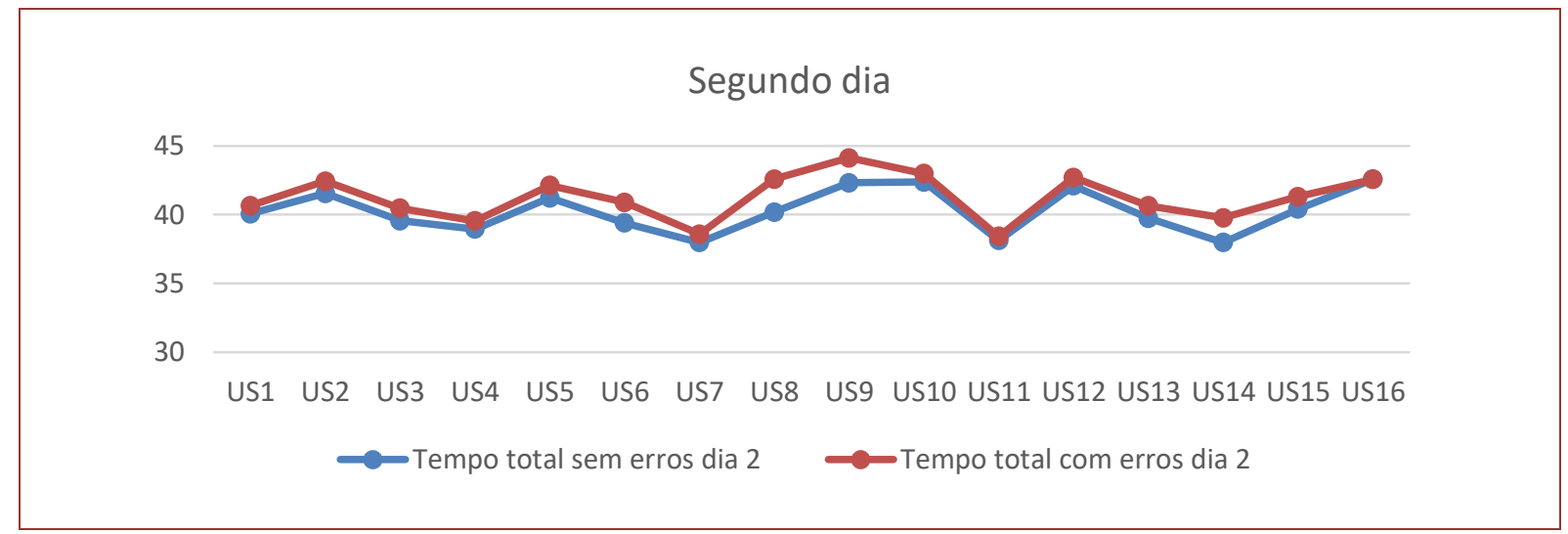

Fonte: Dados do autor, 2020. 
Quadro 3 - Diferença na execução de erros nos dois dias.

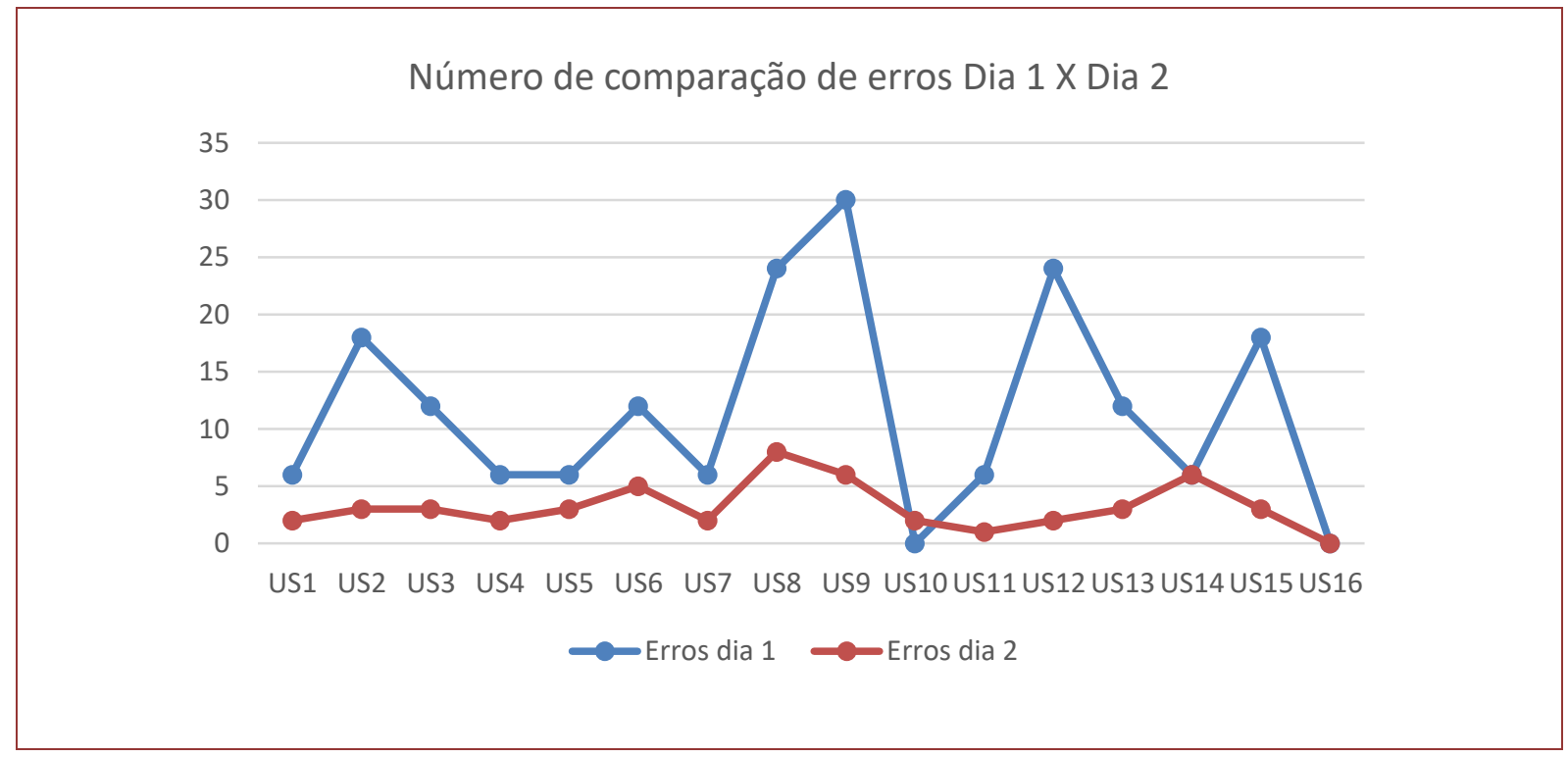

Fonte: Dados do autor, 2020.

Após uma análise comparativa dos tempos com erros do primeiro dia com o segundo dia de atividades, percebemos que 12 dos 16 participantes melhoraram ou mantiveram os tempos em que as atividades foram realizadas (Quadro 4).

Quadro 4 - Análise dos tempos finais com erros das atividades dos dias 1 e 2

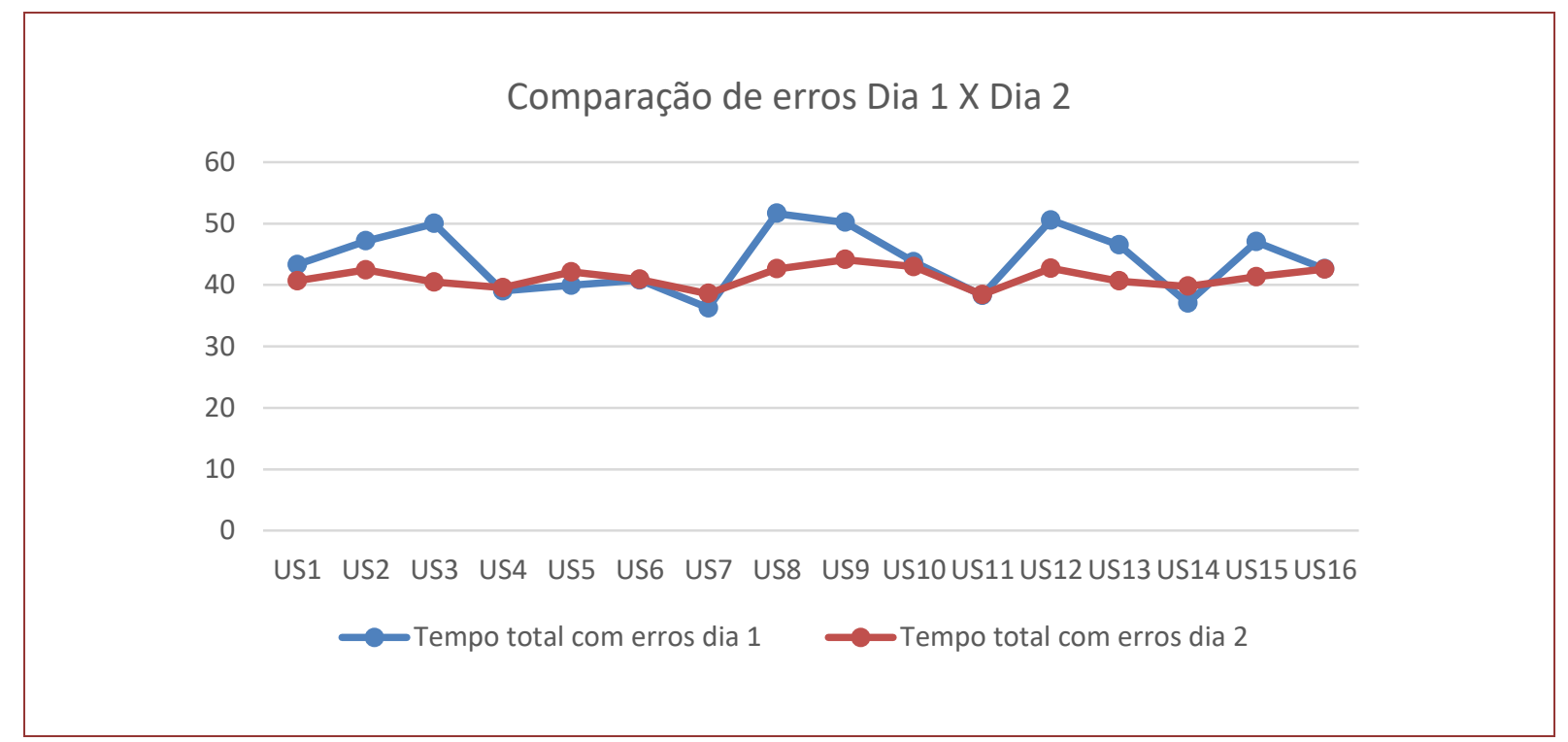

Fonte: Dados do autor, 2020. 


\section{CONCLUSÕES}

Em relação ao baixo custo, as peças que integram o HAA não excedem cinquenta reais e é fácil encontrar todos os dispositivos nas lojas especializadas, e o SAA é um software gratuito, com seu código disponível em: “oculto para avaliação do artigo), respondendo a nossa primeira questão de pesquisa. O SAAM está sendo patenteado pelo "oculto para avaliação do artigo".

Variáveis manipuladas quando observadas pelo usuário, influenciam diretamente na interação deste com o dispositivo (ou dispositivos) assistivos e consequentemente com sua performance, não só humana, mas também das tecnologias assistivas, na realização das atividades, respondendo a nossa segunda questão de pesquisa.

0 SAAM se mostrou eficiente em seus testes quando comparado à taxa de transmissão de um mouse convencional. Notando-se a evolução de 14 dos 16 participantes, que aprimoraram seus conhecimentos nos dois dias de testes no software.

O SAA se apresentou como uma nova função do mouse e pode ser utilizado por qualquer usuário para criar atalhos para seus aplicativos favoritos no próprio SAA, deixando sua área de trabalho sem ícones de atalho. Trabalhando com a HAA, permitiu que os participantes realizassem todas as atividades propostas no experimento de pesquisa.

\section{REFERÊNCIAS}

[1] Alsobhi, A. Y., Nawaz, K., \& Harjinder, R. (2015). "DAEL Framework: A New Adaptive E-learning Framework for Students with Dyslexia". Procedia Computer Science, 51, 1947-1956.

[2] Azmi, A., Alsabhan, N. M., \& AlDosari, M. S. (2009). The Wiimote with SAPI: Creating an accessible low-cost, human computer interface for the physically disabled. International Journal of Computer Science and Network Security, 9(12), 63-68.

[3] Bandeira, I. S., \& Zucatelli, F. H. G. (2016, July). A Human-Computer Interface and an Analysis on the Drawing of Curves with a Face Tracker Mouse. In International Conference on Universal Access in Human-Computer Interaction (pp. 3-14). Springer, Cham.

[4] Biswas, P., \& Langdon, P. (2015). Multimodal intelligent eye-gaze tracking system. International Journal of Human-Computer Interaction, 31(4), 277-294.

[5] Cook, A. M., \& Polgar, J. M. (2014). “Assistive technologies-e-book: principles and practice". Elsevier Health Sciences.

[6] Kurt, S. (2018). "Moving toward a universally accessible web: Web accessibility and education". Assistive Technology.

[7] Laabidi, M., Jemni, M., Ayed, L. J. B., Brahim, H. B., \& Jemaa, A. B. (2014). “Learning 
technologies for people with disabilities". Journal of King Saud University-Computer and Information Sciences, 26(1), 29-45.

[8] MacKenzie, I. S. (2012). "Human-computer interaction: An empirical research perspective”. Newnes, p 130-131.

[9] MacKenzie, I. S. (2012). "Human-computer interaction: An empirical research perspective". Newnes, p 160.

[10] Martins, P., Rodrigues, H., Rocha, T., Francisco, M., \& Morgado, L. (2015). "Accessible options for deaf people in e-learning platforms: technology solutions for sign language translation". Procedia Computer Science, 67, 263-272.

[11] Soukoreff, R. W., \& MacKenzie, I. S. (2004). "Towards a standard for pointing device evaluation, perspectives on 27 years of Fitts' law research in $\mathrm{HCI}$ ". International journal of human-computer studies, 61(6), 751-789. 


\section{Capítulo 4}

Gestão socioambiental: Um estudo das ações desenvolvidas pela gestão pública do município Novo Horizonte-BA para promover a sustentabilidade socioambiental $d a$ atividade mineral no garimpo do quartzo rutilado

Manoela Fernanda Pereira da Silva

Lívia da Silva Modesto Rodrigues

André Luiz Rocha de Souza

Alexandre José Alves da Silva 


\section{RESUMO}

0 presente estudo teve por finalidade evidenciar a importância da Gestão Ambiental para a manutenção sustentável da atividade extrativa mineral a partir das ações promovidas pela gestão pública do município de Novo Horizonte na Bahia em relação ao garimpo do quartzo rutilado. A pesquisa buscou identificar os impactos socioambientais ocasionados pela mineração no município estudado e evidenciar as ações de sustentabilidade promovidas pela gestão pública municipal para sanar os impactos da atividade mineral no município. Para realização do estudo, foram utilizadas a pesquisa exploratória, descritiva e explicativa e para levantamento dos dados, foram utilizadas as pesquisas bibliográfica e documental. A pesquisa revelou que a atividade mineral do quartzo rutilado ocasiona impactos tanto socioambientais, como econômicos no município de Novo Horizonte e que a Gestão Pública Municipal, através de ações como a criação da Cooperativa de garimpeiros e da adesão aos 17 Objetivos de Desenvolvimento Sustentável da ONU, vem buscando formas para sanar esses impactos e para promover o desenvolvimento da atividade mineral de forma mais sustentável.

PALAVRAS-CHAVE: Mineração; Gestão Socioambiental; Sustentabilidade 


\section{INTRODUÇÃO}

A história da civilização humana está diretamente relacionada à exploração dos recursos naturais. Para Lopes (2013, p. 11) "a exploração de recursos naturais pautou o crescimento e desenvolvimento de diversas nações ao redor do planeta". Para ele, países como EUA e Inglaterra, por exemplo, devem muito de seus atuais patamares de desenvolvimento à utilização de recursos agrícolas, florestais, minerais e aos combustíveis fósseis. Já para nações como Austrália e Canadá, os recursos naturais foram e ainda são fontes importantes no fomento ao crescimento e desenvolvimento, além de serem exemplos de nações que conseguiram desenvolver uma cadeia produtiva ao redor da exploração de seus recursos (LOPES, 2013).

Dentre as "classes" (SUSLICK et at, 2005) de recursos naturais, os recursos minerais desempenharam e desempenham uma importância significativa no desenvolvimento da civilização humana. Segundo Enríquez (2008), a mineração é uma das mais antigas atividades produtivas exercidas pela humanidade, constituindo-se em um importante setor de crescimento e desenvolvimento econômico de muitas nações.

Entretanto, apesar da incontestável importância histórica e atual da mineração, existe muita polêmica quando ao seu efetivo papel para o desenvolvimento dos espaços onde ocorre (ENRÍQUEZ, 2008). Questões relativas à natureza exaurível desses recursos e aos impactos sociais e ambientais negativos ocasionados pela atividade vieram à tona durante o século XX. Tais questões ganharam força a partir da segunda metade do século XX e permanecem centrais nas discussões a respeito do impasse entre desenvolvimento econômico e preservação ambiental.

Nessa perspectiva, para que a atividade minerária seja sustentável é necessário que, além do desenvolvimento econômico, ela esteja alinhada com a promoção e manutenção do equilíbrio socioambiental. Para que isso ocorra, as organizações, sejam elas do setor privado ou do setor público, precisam estar alinhadas com práticas voltadas para a responsabilidade social, um dos aspectos mais visíveis do movimento gerado em torno da questão ambiental nos últimos anos (DIAS, 2011).

De acordo a Matias-Pereira (2012), o principal desafio da gestão pública contemporânea é promover o desenvolvimento econômico e social sustentável. Frente a esse contexto, o presente trabalho visa responder o seguinte problema de pesquisa: As ações de sustentabilidade promovidas pela Gestão Pública Municipal de Novo Horizonte com relação ao garimpo do quartzo rutilado serão capazes de promover o 
desenvolvimento sustentável dessa atividade no município?

O objetivo principal desse estudo é evidenciar a importância da Gestão Ambiental para a manutenção sustentável da atividade extrativa mineral, a partir das ações promovidas pela gestão pública do município de Novo Horizonte na Bahia para promover a sustentabilidade do garimpo do quartzo rutilado.

Como objetivos específicos, o artigo tem a finalidade de identificar os impactos socioambientais ocasionados pela mineração no município estudado e evidenciar as ações de sustentabilidade promovidas pela gestão pública municipal para sanar os impactos da mineração no município.

Além dessa introdução e das considerações finais, esse artigo possui mais três partes. Primeiramente apresenta-se a descrição dos conceitos e definições que guiaram a condução teórica desse estudo, com a apresentação da literatura sobre gestão ambiental e desenvolvimento sustentável. Em seguida, faz-se uma abordagem a respeito dos procedimentos metodológicos utilizados para realização da pesquisa. E por fim, são apresentados os principais impactos ocasionados pela atividade mineral no município de Novo Horizonte e sobre as ações praticadas pela gestão pública municipal para sanar esses impactos e promover o desenvolvimento municipal de forma sustentável nas dimensões econômicas, social e ambiental.

\section{REFERENCIAL TEÓRICO: CONCEITOS E DEFINIÇÕES}

\subsection{DESENVOLVIMENTO SUSTENTÁVEL}

As preocupações com relação à disponibilidade dos recursos naturais datam do século XVII, quando o economista inglês Thomas Malthus observou que o crescimento demográfico era maior do que os meios de subsistência, pois enquanto a população crescia em progressão geométrica, a produção de alimentos ocorria em progressão aritmética (SUSLICK et al, 2005).

A Revolução Industrial iniciada no século XVIII na Inglaterra, promoveu o crescimento econômico e abriu as perspectivas de maior geração de riquezas, entretanto, o crescimento econômico desordenado promoveu uma degradação contínua do meio ambiente devido ao consumo excessivo dos recursos naturais (DIAS, 2011).

Embora Thomas Malthus já no século XVII tivesse levantando a questão sobre a possível escassez dos recursos naturais, somente a partir da década de 70 do século XX é que a visão de que os recursos naturais são limitados começou a surgir. A partir dessa 
época é que "os processos de deterioração ambiental e a possibilidade de esgotamento de determinados recursos naturais se tornaram mais evidentes" (DIAS, 2011, p. 7).

Dias (2011) afirma que, somente na segunda metade do século XX, devido a intensificação do crescimento econômico mundial, é que os problemas ambientais se agravaram e começaram a aparecer com maior visibilidade para amplos setores da população, particularmente para os países desenvolvidos, os primeiros a serem afetas pelos impactos gerados pela Revolução Industrial.

Segundo esse autor, foi no início da década de 70 que se tornaram mais consistentes os questionamentos sobre os modelos de crescimento e desenvolvimento econômico que perdurava desde a Revolução Industrial. Para ele, os questionamentos pautavam-se na ideia de que, embora tivesse havido profundas mudanças na economia, os níveis de subdesenvolvimento e pobreza não abaixavam e que a desigualdade social entre os países desenvolvidos e subdesenvolvidos se tornava cada vez maior. (DIAS, 2011).

Como resposta a esses questionamentos, surgiu o conceito desenvolvimento sustentável como proposta para aliar o desenvolvimento econômico, incluindo o meio ambiente natural e sociocultural, "revelando que a qualidade de vida dos seres humanos passa a ser condição para o progresso (DIAS, 2011, P. 35).

Conforme Dias (2011), o conceito básico de desenvolvimento sustentável emergiu na Conferência das Nações Unidas sobre o Meio Ambiente Humano em 1972, conhecida como Conferência de Estocolmo, em referência à cidade de Estocolmo, na Suécia, onde foi realizada. A Conferência de Estocolmo representou uma verdadeira ruptura com as visões tradicionais de meio ambiente, sendo comum dividir a evolução do debate ambiental em antes e depois de Estocolmo (PEARSON EDUCATION DO BRASIL, 2011).

Ao final da Conferência, foi firmada a Declaração sobre Meio Ambiente, cujos princípios, de acordo a Thomé (2014), constituem um prolongamento da Declaração Universal dos Direitos Humanos e proclama que a defesa e a melhoria do meio ambiente para as gerações futuras devam se converter num objetivo imperioso para a humanidade.

O termo desenvolvimento sustentável só veio a ser utilizado em 1987, no Relatório Brundtland (Nosso Futuro Comum), fruto da Comissão Mundial para o Desenvolvimento e Meio Ambiente (CMDMA), criada pelas Assembleia Geral da ONU em 
1983. Nesse relatório, é apresentado o conceito de desenvolvimento sustentável, o qual tem por fundamento promover o desenvolvimento econômico sem comprometer o atendimento às necessidades das gerações futuras (PEARSON EDUCATION DO BRASIL, 2011).

No relatório, desenvolvimento sustentável é definido como "aquele que atende às necessidades do presente sem comprometer a possibilidade de as gerações futuras atenderem as suas próprias necessidades" e possui dois conceitos-chave (CMMAD, 1991, p. 46): O conceito de "necessidades", sobretudo as necessidades essenciais dos pobres no mundo, que devem receber a máxima prioridade; e a noção das limitações que o estágio da tecnologia e da organização social impõe ao meio ambiente, impedindo-o de atender às necessidades presentes e futuras.

Para Thomé (2014), o desenvolvimento sustentável tem como pilar a harmonização de três vertentes: crescimento econômico, preservação ambiental e equidade social. Segundo ele, o desenvolvimento só pode ser considerado sustentável se as três vertentes forem respeitadas de forma simultânea. Ou seja, o desenvolvimento só pode ser considerado sustentável se conseguir promover ao mesmo tempo o crescimento econômico, a preservação do meio ambiente e a redução das desigualdades sociais.

No que tange à mineração, o conceito apresentado de desenvolvimento sustentável aparentemente conflita com essa atividade, uma vez que os bens minerais são recursos não-renováveis (ENRÍQUEZ, 2008). Além disso, conforme exposto anteriormente, a atividade mineral gera impactos sociais e ambientais que vão de encontro ao proposto para o desenvolvimento sustentável. Como então conciliar a atividade de exploração mineral com os princípios da sustentabilidade?

No artigo Mineração e Desenvolvimento Sustentável - é possível conciliar? Enríquez (2009) afirma que, levando-se em consideração a natureza exaurível dos recursos minerais, para que a mineração possa ser considerada uma atividade sustentável ela precisa promover a equidade da atual geração (intrageração) e das gerações futuras (intergeração). Na perspectiva da geração atual, a mineração apenas pode ser considerada sustentável se minimizar os seus impactos ambientais e mantiver certos níveis de proteção ecológica e de padrões de qualidade ambientais. Já na perspectiva das gerações futuras, a atividade deve garantir o uso sustentado das rendas que a mineração proporcionou. 
Com base na perspectiva da intergeração, Lopes (2013) afirma que, apesar da mineração não ser considerada uma atividade sustentável se analisada isoladamente, a renda gerada por ela pode ser utilizada para construir economias que sejam sustentáveis, através do investimento em infraestrutura, capital humano, recursos naturais renováveis e no fortalecimento das instituições, além de empregado em melhorias nas condições de vida da população.

Nesse sentido, Rodrigues (2016, p. 60) afirma que "o conceito de desenvolvimento sustentável, no contexto das corporações mineiras, requer a adoção das melhores práticas ambientais e socioeconômicas, configurando posicionamento preventivo e social" e que a adoção dessas práticas não deve ser feita apenas pelas empresas mineradoras, mas também pelos municípios que recebem os recursos provenientes da Compensação Financeira pela Exploração dos Recursos Minerais CFEM, destinando-os de forma adequada para a sociedade.

Os recursos advindos da atividade mineral, quando aplicados adequadamente, favorecem o desenvolvimento das comunidades em seu entorno sob o ponto de vista socioeconômico. Além disso, se gerenciada de modo responsável, a mineração promove a conservação do meio ambiente e dos serviços ecossistêmicos, mantendo-a ao longo de sua existência e após cessar suas ações (IBHAM, 2014).

\subsection{GESTÃO AMBIENTAL}

A gestão ambiental é definida pela Pearson Education do Brasil (2011, p. 97) “como o braço da administração que reduz o impacto das atividades econômicas sobre a natureza. Ela deve estar presente em todos os projetos de uma organização, desde seu planejamento e execução até sua completa desativação.

Segundo Dias (2011), o objetivo da gestão ambiental é conseguir que os efeitos ambientais ocasionados pelas empresas não ultrapassem a capacidade de carga do meio onde se encontra a organização. Para o autor, a gestão ambiental é o principal instrumento para se obter um desenvolvimento industrial sustentável.

O desenvolvimento sustentável nas organizações, conforme Dias (2011) está pautado em três dimensões: a econômica, a social e a ambiental. Para se desenvolver de forma sustentável, uma empresa deve atuar de forma que esses três pilares coexistam e interajam entre si de forma plenamente harmoniosa.

Do ponto de vista econômico, as empresas têm que ser economicamente viáveis, 
ou seja, precisam dar retorno ao investimento realizado pelo capital privado. No aspecto social, as empresas devem proporcionar melhores condições para o capital humano da empresa a participar ativamente das atividades socioculturais de expressão da comunidade que vive no entorno da unidade produtiva. Em termos ambientais, as organizações devem pautar-se na ecoeficiência dos seus processos produtivos, adotando uma produção mais limpa e uma postura de responsabilidade social (DIAS, 2011).

O processo de gestão ambiental nas empresas está vinculado ás normas que são elaboradas pelas instituições públicas (Governos Federal, Estadual e Municipal) sobre o meio ambiente. Estas normas são referência obrigatória para empresas que pretendem implantar um Sistema de Gestão Ambiental (SGA). Entretanto, em função da cultura ambiental predominante nas empresas, a maior parte dos esforços aplicados nos SGA está ligado à aplicação de técnicas corretivas, como reciclagem, armazenamento de resíduos etc. (DIAS, 2011).

A administração pública deve ser a principal percussora para a iniciativa de ações de sustentabilidade e de desenvolvimento que estimule a população a adotar práticas ambientais sustentáveis. Segundo Matias-Pereira (2012), o principal desafio dos governos e da administração pública no mundo contemporâneo é promover o desenvolvimento econômico e social sustentável. Este desafio impõe aos governos e às administrações públicas, a necessidade de repensar a questão da governança e do modelo de gestão pública, exigindo ao mesmo tempo práticas inovadoras de relacionamento com a sociedade (MATIAS-PEREIRA, 2012).

Ainda de acordo a Matias-Pereira (2012), a função principal dos governos e da administração pública no mundo contemporâneo é ampliar de forma sistemática as oportunidades individuais, institucionais e regionais e gerar estímulos para facilitar a incorporação de novas tecnologias e inovações que possibilite o atendimento das demandas da sociedade contemporânea.

\section{PROCEDIMENTOS METODOLÓGICOS}

Os procedimentos metodológicos utilizados neste estudo foram a pesquisa exploratória, descritiva e explicativa. A pesquisa exploratória teve como objetivo proporcionar maior familiaridade com o problema, investigando o estágio em que se encontram as informações já disponíveis sobre o assunto estudado (GERHARDT e SILVEIRA, 2009). A pesquisa descritiva teve como finalidade principal, conforme Gil 
(1999), a descrição das características do fenômeno estudado e o estabelecimento de relações entre variáveis. Já a pesquisa explicativa foi utilizada para identificar os fatores que determinaram ou que contribuíram para a ocorrência do fenômeno estudado, ou seja, nesse momento da pesquisa são feitas as considerações a respeito do porquê da ocorrência de determinadas coisas através dos resultados obtidos na pesquisa exploratória (GIL, 1999).

Para coleta de dados, foram utilizadas a pesquisa bibliográfica e documental. A pesquisa bibliográfica, ou de fontes secundárias, abrange toda a bibliografia já tornada pública em relação ao tema estudado e sua finalidade é colocar o pesquisador em contato com tudo o que já foi escrito, dito ou filmado sobre determinado assunto (LAKATOS E MARCONI, 2008).

Já na pesquisa documental, a fonte de coleta de dados será restrita a documentos de fontes primárias, podendo ser recolhidos no momento em que o fato ou fenômeno ocorreu ou não (LAKATOS e MARCONI, 2008). Segundo Gil (1999), a pesquisa documental é muito semelhante à pesquisa bibliográfica. A diferença essencial entre ambas está na natureza das fontes: enquanto a bibliográfica se utiliza fundamentalmente das contribuições de diversos autores, a documental vale-se de materiais que não receberam, ainda, um tratamento analítico, podendo ser reelaboradas de acordo com os objetos da pesquisa.

A pesquisa documental foi baseada principalmente em reportagens de jornais, site oficial da Prefeitura do município estudado e no Projeto Pedagógico e Diretrizes Curriculares Municipais do município de Novo Horizonte coletado junto à Secretaria de Educação Municipal.

\section{RESULTADOS ALCANÇADOS}

\subsection{ASPECTOS SOCIOECONÔMICOS E DEMOGRÁFICOS DE NOVO HORIZONTE/BA}

Localizado a $553 \mathrm{~km}$ de Salvador, Novo Horizonte é um dos municípios mais novos do Estado da Bahia. Conquistou a emancipação política em 13 de junho de 1989, através de plebiscito popular, conforme Lei Estadual no. 5020. Até então, pertencia ao município de Ibitiara. É um dos 24 municípios que compõem o Território de Identidade da Chapada Diamantina, importe região histórica e turística do Estado da Bahia.

Com população estimada em 12.385 habitantes (IBGE, 2020), Novo Horizonte nasceu na primeira metade do século XX graças à extração e o comércio de ouro na 
região da Chapada Diamantina. Atualmente, o município vive da extração mineral, principalmente do garimpo do quartzo rutilado e da barita, e da produção agrícola. De acordo com a estimativa da prefeitura local, 30\% da economia do município é agrícola, enquanto $60 \%$ da população vive direta ou indiretamente da mineração (GOMES, 2019a).

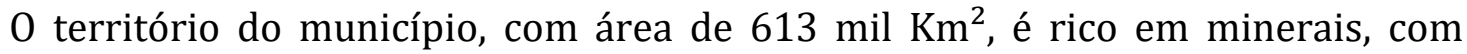
destaque, segundo Santos (2019. p. 80) para a "produção do quartzo rutilado, cristal transparente, ouro barita, granito, mármore, ferro etc.”. Novo Horizonte também se destaca na produção de alho na região do Distrito do Brejo Luiza de Brito, ocupando, em 2017, a primeira colocação como o maior produtor de alho do estado da Bahia, sendo responsável, segundo dados da Prefeitura Municipal (2020), por 40\% da produção de alho do estado. Toda a produção agrícola do município é realizada através da agricultura familiar.

A história do município de Novo Horizonte, assim como de muitos outros municípios baianos, está diretamente relacionada à exploração mineral. Primeiramente com a exploração do ouro e do quartzo hialino, ou cristal-de-rocha, e mais recentemente com a exploração do quartzo rutilado, uma forma de quartzo caracterizado pela presença de agulhas ou fios de rutilo na estrutura do cristal. 0 rutilo ou quartzo rutilado é um cristal muito utilizado em joias e também nas áreas da tecnologia e eletrônica, na confecção de chips para celulares e a utilização em bombas nucleares (ARAUJO ET AL, 2018).

Devido ao garimpo do rutilo, Novo Horizonte tornou-se um forte atrativo para garimpeiros de diversas regiões do país, comerciantes, pesquisadores e investidores estrangeiros, gerando oportunidades de trabalho e aquecendo a economia local (NOVO HORIZONTE, 2018). Além disso, a atividade mineral do quartzo rutilado também atrai compradores de outros países, principalmente europeus e asiáticos, que exportam toneladas de cristais rutilados.

\subsection{IMPACTOS SOCIOAMBIENTAIS DA MINERAÇ̃̃O E GESTÃo PÚBLICA MUNICIPAL}

O paradoxo entre o desenvolvimento econômico e a preservação ambiental aparece como uma constante ao longo da segunda metade do século XX e se intensifica nas duas primeiras décadas do século XXI. É justamente em face desse dilema que surge a ideia de desenvolvimento sustentável. A harmonia entre crescimento econômico, 
preservação ambiental e equidade social são, segundo Thomé (2014), os pilares do desenvolvimento pautados na sustentabilidade. Sendo assim, promover o desenvolvimento de forma sustentável deveria ser um dos principais objetivos da gestão das organizações no setor público, seja ele federal, estadual ou municipal.

Entretanto, conforme Enríquez (2008), quando se trata da atividade de exploração dos recursos minerais, os princípios de sustentabilidade se tornam mais difíceis de serem conciliados, uma vez que os recursos minerais são limitados na natureza e a sua retirada pode causar severos danos ao ambiente onde ocorre. Contudo, Enríquez (2008) também afirma que para que a mineração seja considerada sustentável, é necessário mitigar os impactos ambientais causados por esta atividade, garantindo que a renda proveniente da mineração seja devidamente aplicada nas áreas sociais.

De acordo ao Projeto Pedagógico e Diretrizes Curriculares Municipais de Novo Horizonte, a exploração mineral do rutilo no município não foi capaz de proporcionar uma melhoria na qualidade de vida do trabalhador e da população local de forma relevante. Além disso, a atividade compromete a sustentabilidade social, ambiental e econômica do município devido à ocorrência da exploração informal das pedras preciosas em vários garimpos espalhados pelo município (NOVO HORIZOTE, 2018).

A informalidade da atividade no município ocasiona uma série de problemas que comprometem a sustentabilidade da mineração. No âmbito social, a informalidade gera condições de trabalho precárias, com alto nível de periculosidade e insalubridade do processo de exploração (NOVO HORIZOTE, 2018). Os garimpos de rutilo são formados basicamente por uma escavação subterrânea que, dependendo do local, pode chegar a muitos metros de profundidade, por onde os trabalhadores, através da utilização de um guincho, descem e sobem no processo de perfuração da rocha, sem utilizar nenhum equipamento de proteção individual (EPI), tampouco equipamentos de segurança (ARAUJO ET AL, 2018).

De acordo a Araújo et al (2018), a maioria dos garimpos de Novo Horizonte costuma ter práticas de exploração do trabalho, caracterizado pelas intensas horas de trabalho e condições precárias, localizados em áreas sem licença ambiental. Ainda de acordo às autoras, por serem localizados em áreas de exploração não legalizada, os garimpos de rutilo são ocupados por pessoas em situação de vulnerabilidade social, atuando como mão de obra barata e ficando à disposição dos proprietários dos garimpos todos os dias, já que $90 \%$ da categoria são itinerantes, ou seja, são pessoas que 
vêm de outros municípios e até mesmo de outros estados em busca das riquezas prometidas pelo garimpo. Desta forma, por estarem trabalhando numa situação irregular, a maioria não tem carteira assinada (ARAUJO ET AL, 2018).

Além de todos esses problemas apresentados, a exploração contínua no garimpo, sem nenhum tipo de amparo social, pode levar o trabalhador a desenvolver doenças provenientes da atividade garimpeira, como a silicose, causada pela inalação da poeira do garimpo, além dos acidentes de trabalho (ARAUJO ET AL, 2018), que em muitos casos, podem levar a morte ou invalidez do trabalhador.

De acordo ao Projeto de Educação e as Diretrizes Curriculares Municipais de Novo Horizonte (NOVO HORIZONTE, 2018), a atividade extrativista mineral termina por impactar também o processo de escolarização, contribuindo, juntamente com outros fatores, para a ampliação das taxas de abandono escolar de estudantes influenciados pela flutuação da população e também por jovens que deixam de estudar para trabalharem na exploração do garimpo.

Do ponto de vista ambiental, a maior parte dos impactos ao meio ambiente que atividade mineral em Novo Horizonte vem ocasionando está relacionada ao desmatamento, contaminação do solo por resíduos sólidos, descaracterização do relevo devido às perfurações que são feitas nas rochas para extrair o minério; redução da biodiversidade, poluição sonora ocasionada pelas explosões, emissão de gases poluentes, produção de material sedimentado, degradação da paisagem, alteração de cursos d'água e alteração dos processos geológicos (erosão) (NOVO HORIZONTE, 2018).

Segundo o Instituto do Meio Ambiente e Recursos Hídricos (INEMA) de Seabra, há vários processos relacionados às denúncias de irregularidade do garimpo do município, além de vários relatórios registrados no Ministério Público (ARAUJO ET AL, 2018). Esses processos estão relacionados à ilegalidade da atividade e aos problemas sociais e ambientais que foram citados.

Devido a informalidade do garimpo de rutilo em Novo Horizonte, o município sofreu em outubro de 2012 uma apreensão da Polícia Federal, denominada de Operação Pedra Furada, que teve como objetivo a repressão da exploração, comercialização e exportação ilegal do quartzo rutilado e da utilização irregular de explosivos nos garimpos (G1 BA, 2012). Nessa apreensão da PF, muitos proprietários de área do garimpo tiveram seus bens apreendidos, além da emissão de multas e processos encaminhados ao Ministério Público (ARAUJO ET AL, 2018). 
No que tange aos aspectos econômicos, Segundo SILVA et al (2020) apesar da produção do quartzo rutilado em Novo Horizonte representar, segundo dados da Prefeitura Municipal (2020), mais da metade da economia do município, os valores referentes a essa produção não são associados ao PIB, uma vez que parte do rendimento proveniente da atividade não deve ser contabilizado devido à atuação informal de boa parte dos garimpos de quartzo rutilado. Ainda de acordo a SILVA et al (2020), segundo informações fornecidas pelo site oficial da Prefeitura Municipal (2020), a exploração mineral do rutilo em Novo Horizonte não foi capaz de proporcionar uma melhoria na qualidade de vida da população do município, apesar de ser uma importante atividade econômica para a economia local. Isso ocorre porque a busca desenfreada pelo garimpo acaba provocando desinteresse por outras atividades econômica, fenômeno que pode ser relacionado, segundo os autores, com a tese da "maldição dos recursos", que alerta para o fato de que locais ricos em recursos minerais acabam tendo dificuldades para alcançar o desenvolvimento econômico, visto que atividade mineral pode dificultar o desempenho de outras atividades produtivas (ENRIQUEZ, 2008).

No estudo realizado por SILVA et al (2020), a partir da análise da arrecadação da Compensação Financeira pela Exploração dos Recursos Minerais (CFEM) feita pelo município de Novo Horizonte entre os anos de 2006 a 2019, não foi evidenciada uma relação direta entre o crescimento do PIB do município no período e a atividade mineral, já que, devido à informalidade do garimpo do quartzo rutilado, a arrecadação municipal da CFEM está muito abaixo de toda produção mineral do município nos anos estudados. Contudo, de acordo ao estudo, de forma indireta, a mineração promove a geração de renda e o aquecimento do comércio local através da movimentação financeira que ocorre através das negociações das pedras (SILVA ET AL, 2020).

Com o intuito de regulamentar a atividade extrativa mineral do município, principalmente do garimpo do quartzo rutilado, foi criada em 2011 a Cooperativa de Garimpeiros de Novo Horizonte, que propiciou, segundo o presidente da cooperativa, Sr. Flavio Junior, em entrevista ao Jornal Correio em 2019, o acesso do município a assistência técnica, mapeamento geológico e programas ambientais, algo que não era possível anteriormente, devido à ilegalidade da atividade. Mesmo assim, ainda existem muitos garimpos espalhados pelo munícipio que funcionam sem regularização.

A cooperativa que iniciou suas atividades com 12 filiados, conta atualmente com 611 garimpeiros. De acordo ao presidente da cooperativa, inicialmente, houve 
resistências, dificuldades na adaptação, mas hoje quem vive da extração das riquezas minerais em Novo Horizonte acredita que o processo é compensatório. Hoje, os associados participam de ações para o reflorestamento de áreas dentro da cooperativa e de recuperação de áreas degradadas (GOMES, 2019b).

Outra ação promovida pela gestão do município para desenvolver melhores práticas de gestão ambiental, principalmente relacionadas à atividade mineral, foi a adesão oficial do município aos 17 Objetivos de Desenvolvimento Sustentável (ODS) das Nações Unidas em maio de 2019. Com a adesão à Agenda 2030 da ONU, o município da Chapada Diamantina objetiva dar mais visibilidade às sete ações de sustentabilidade que já vem sendo realizadas no município, de acordo ao Sr. Djalma dos Anjos, e que fazem parte dos 17 Objetivos de Desenvolvimento Sustentável (CORREIO 24 HORAS, 2019).

As 07 ações de sustentabilidade já implementadas no município, segundo o Prefeito Djalma dos Anjos, são: investimentos em redução da pobreza, educação inclusiva, água, saneamento, moradias e energia para todos, além da industrialização inclusiva, a proteção e a recuperação de áreas de vegetação nativa. Ainda de acordo ao Prefeito, a adesão do município aos ODS foi pautada nas próprias necessidades da comunidade local (VASCONCELOS, 2019).

Os Objetivos de Desenvolvimento Sustentável (ODS) são uma agenda mundial adotada durante a Cúpula das Nações Unidas sobre o Desenvolvimento Sustentável em setembro de 2015, composta por 17 objetivos e 169 metas a serem atingidos até 2030 . Nesta agenda estão previstas ações mundiais nas áreas de erradicação da pobreza, segurança alimentar, agricultura, saúde, educação, igualdade de gênero, redução das desigualdades, energia, água e saneamento, padrões sustentáveis de produção e de consumo, mudança do clima, cidades sustentáveis, proteção e uso sustentável dos oceanos e dos ecossistemas terrestres, crescimento econômico inclusivo, infra-estrutura, industrialização, entre outros (BRASIL, 2020).

Com a adesão do município de Novo Horizonte aos ODS, a Cooperativa de Garimpeiros também se comprometeu a desenvolver estratégias para garantir o cumprimento dos Objetivos de Desenvolvimento Sustentável. A Cooperativa, segundo Araújo et al (2018), já coordena projetos voltados para o reflorestamento das áreas desmatadas, fomento de viveiro, compra de explosivos e de equipamento de segurança para os garimpeiros.

De acordo ao gerente de empreendimentos minerais da Companhia Baiana de 
Pesquisa Mineral (CBPM), Adalberto Ribeiro, há uma necessidade de se reduzir os impactos ambientais no setor da mineração, uma das atividades mais importantes para Novo Horizonte. Para Adalberto Ribeiro, o minério tem uma vida útil e não é para sempre, sendo muito importante que a sociedade e suas lideranças tenham conhecimento de suas riquezas, porque só assim será possível administrá-las (CORREIO 24 HORAS, 2019).

\section{CONSIDERAÇÕES FINAIS}

Este estudo buscou identificar as ações de sustentabilidade promovidas pela Gestão Pública Municipal de Novo Horizonte com relação ao garimpo do quartzo rutilado com o objetivo de evidenciar a importância da Gestão Ambiental para a manutenção sustentável da atividade extrativa mineral. 0 estudo buscou, primeiramente, identificar os impactos socioambientais ocasionados pela mineração no município estudado e, em seguida, evidenciar as ações de sustentabilidade promovidas pela gestão pública municipal para sanar os impactos da mineração no município.

Os resultados alcançados revelam que o garimpo do quartzo rutilado gera impactos sociais e ambientais das áreas afetadas devido, principalmente, à exploração informal das pedras preciosas nos garimpos espalhados pelo município, sendo necessários estudos mais detalhados para evidenciar a dimensão desses impactos e de que forma eles atingem a comunidade local.

O estudo também revelou que a gestão municipal de Novo Horizonte vem promovendo ações para tornar a atividade mineral do município mais sustentável, através da criação da cooperativa de garimpeiros, que iniciou o processo de legalização da atividade, e da adesão do município aos 17 Objetivos de Desenvolvimentos Sustentável da ONU. Essas ações podem significar o início de um processo para tornar a atividade mineral mais sustentável no município de Novo Horizonte, promovendo uma melhoria das condições de saúde, educação, saneamento e também na preservação ambiental das áreas afetadas.

Recomenda-se novos estudos no intuito de evidenciar a influência dos impactos socioambientais causados pelo garimpo do rutilo no desenvolvimento social e econômico do município, bem como as estratégias utilizadas pela gestão pública municipal para colocar em prática os 17 ODS. 


\section{REFERÊNCIAS}

[1] BRASIL. Ministério das Relações Exteriores. Objetivos de Desenvolvimento Sustentável (ODS). Brasília: MRE, 2020.Disponível em http://www.itamaraty.gov.br/pt$\mathrm{BR} /$ politica-externa/desenvolvimento-sustentavel-e-meio-ambiente/134-objetivos-dedesenvolvimento-sustentavel-ods. Acesso em 27/03/2020.

[2] CADERNO Especial de Mineração. Jornal Correio. Salvador, 21/09/2019. Disponível em: http://www.cbpm.ba.gov.br/2019/08/3811/Jornal-Correio-publicacaderno-especial-de-mineracao-em-parceria-com-a-CBPM.html. Acesso em 01/09/2019.

[3] CMMAD. Comissão Mundial sobre Meio Ambiente e Desenvolvimento. Nosso Futuro Comum. 2.ed. Rio de Janeiro: Editora da Fundação Getúlio Vargas, 1991. Disponível

em:https://edisciplinas.usp.br/pluginfile.php/4245128/mod_resource/content/3/Noss o\%20Futuro\%20Comum.pdf. Acesso em 07/03/2020;

[4] CORREIO 24 HORAS.Novo Horizonte adota os Objetivos de Sustentabilidade da ONU. Salvador, 29 de maio de 2019. Disponível em: https://www.correio24horas.com.br/noticia/nid/novo-horizonte-adota-os-objetivosde-sustentabilidade-da-onu/. Acesso: 10/08/2019.

[5] GOMES, Donaldson. Nova era na mineração baiana. Notícias sobre mineração. Salvador: Correio 24 Horas, 30 de julho de 2019.

[6] . Cooperativa é alternativa para garimpeiros de Novo Horizonte. Salvador: Correio 24 Horas, 08 de agosto de 2019. Disponível em: https://www.correio24horas.com.br/noticia/nid/cooperativa-e-alternativa-paragarimpeiros-de-novo-horizonte/. Acesso em 08/01/2020.

[7] G1 BAHIA. Polícia Federal deflagra operação e prende brasileiros e chineses na BA. 2012. Disponível em: http://g1.globo.com/bahia/noticia/2012/10/policia-federaldeflagra-operacao-e-prende-brasileiros-e-chineses-na-ba.html. Acesso em 11/04/2020.

[8] DIAS, Reinaldo. Gestão Ambiental: responsabilidade social e sustentabilidade. 2.ed. São Paulo: Atlas, 2011.

[9] ENRIQUEZ, M. A. R. S. Maldição ou dádiva.? Os dilemas do desenvolvimento sustentável a partir de uma base mineira. 2007. Tese de Doutorado, Centro de Desenvolvimento Sustentável, Universidade de Brasília. Brasília.

[10] Mineração e desenvolvimento sustentável - é possível conciliar? Revista de La Red Ibmeroamericana de Economia Ecológica, Rio de Janeiro, v. 12, p. 51-66, 2009. Disponível em https://redibec.org/. Acesso em 02/01/2020.

[11] GERHARDT, Tatiana Engel; SILVEIRA, Denise Tolfo. Métodos de pesquisa. Porto Alegre: Editora da UFRGS, 2009.

[12] GIL, Antônio Carlos. Métodos e técnicas de pesquisa social. 5.ed. São Paulo: Atlas, 1999.

[13] IBGE. Instituto Brasileiro de Geografia e Estatística. 2020. Novo Horizonte. Disponível em: https://cidades.ibge.gov.br/brasil/ba/novo-horizonte/historico. Acesso em 08/01/2020.

[14] LAVILLE, Christian; DIONNE, Jean. A Construção do Saber: manual de metodologia da pesquisa em ciências humanas. Trad. Heloisa Monteiro e Francisco Settineri. Porto 
alegre: Editora Artes Médicas Sul Ltda.; Belo Horizonte: Editora UGMG, 1999.

[15] LOPES, Rafael Tadeu Rodrigues. Mineração e desenvolvimento: uma análise da maldição dos recursos naturais para os estados brasileiros. 2013. 78 f. Dissertação (mestrado) - Universidade Estadual Paulista Julio de Mesquita Filho, Faculdade de Ciências e Letras, 2013. Disponível em: <http://hdl.handle.net/11449/89996>.Acesso em 03/02/2020.

[16] MARCONI, Marina de A; LAKATOS, Eva Maria. Técnicas de Pesquisa: planejamento $e$ execução de pesquisas, amostragens e técnicas de pesquisa, elaboração, analise e interpretação de dados. 7.ed. São Paulo: Atlas, 2008.

[17] MATIAS-PEREIRA, José. Manual de gestão pública contemporânea. 4. Ed. São Paulo: Atlas, 2012.

[18] NOVO HORIZONTE, Prefeitura Municipal de. 2020. Disponível em: https://www.novohorizonte.ba.gov.br/. Acesso 10/08/2019.

[19] - Secretária Municipal de Educação. Projeto Pedagógico e Diretrizes Curriculares Municipais.Novo Horizonte/BA, 2018. p. 1 - 80.

[20] PEARSON EDUCATION DO BRASIL. Gestão Ambiental. São Paulo: Person Pretice Hall, 2011.

[21] RODRIGUES, Lívia da S. Modesto. Atividade de Mineração do Semiárido da Bahia: Um Modelo Para Evidenciação da Sustentabilidade Ambiental. 2016. Tese (Doutorado em Geologia Ambiental) - Instituto de Geociências, Universidade Federal da Bahia. Salvador.

[22] SANTOS, Laércio Fernandes. Novo Horizonte: Espelho do passado e outros causos. 1. Ed. Salvador: Artegraf, 2019.

[23] SEIFFERT, Mari Elizabete Bernardini. ISO 14001 Sistema de Gestão Ambiental: implantação objetiva e econômica. São Paulo: Atlas, 2005.

[24] SILVA, Manoela F. Pereira da et at. Gestão Socioeconômica e ambiental: um estudo dos impactos da atividade mineral no garimpo do quartzo rutilado do município de Novo Horizonte. Brazilian Journals of Business, Curitiba, v. 2, n. 3, p. 1949-1968, jul./set. 2020.

[25] SUSLICK, Saul B.; MACHADO, Iran F.; FERREIRA, Doneivan F. Recursos Minerais e Sustentabilidade. Campinas, SP: Komedi, 2005.

[26] THOMÉ, Romeu. Manual de Direito Ambiental. Salvador/BA: Editora JUSPODIVM, $4^{\mathrm{a}}$ ed, 2014.

[27] VASCONCELOS, Carmem. Novo Horizonte é nova cidade baiana a adotar a Agenda 2030 da ONU. Salvador: Correio 24 Horas, 16 de maio de 2019. Disponível em: https://www.correio24horas.com.br/noticia/nid/novo-horizonte-e-nova-cidadebaiana-a-adotar-a-agenda-2030-da-onu/. Acesso em: 29/03/2020. 


\section{Capítulo 5}

Bionegócios: perspectivas de desenvolvimento do Território de Identidade de Irecê

Cleiton Braga Saldanha

Jerisnaldo Matos Lopes

Karine Santiago Santos 


\section{RESUMO}

Compreender a Teoria do Desenvolvimento Regional e o conceito de Bionegócios, por meio de seus aspectos econômicos, sociais e ambientais são os objetivos principais desse trabalho. Além do mais, a análise tem como fundamento primordial aplicar todo esse conhecimento ao contexto do Território de Identidade de Irecê, sob a ótica de sua matriz produtiva de base agrícola. Através da contribuição de autores de referência na construção do conhecimento acerca da Teoria do Desenvolvimento Regional e do conceito de Bionegócios, bem como a avaliação de indicadores da produção dos municípios que compõem o Território de Identidade de Irecê, os resultados apontaram para evidências relevantes no sentido de compreender os mecanismos utilizados pelo território, no intuito de ampliar suas estratégias e potencializar a produção regional. Como resultados, diversos fatores foram bastantes significativos para explicar a evolução do desenvolvimento regional, sobretudo considerando o PIB e a dinâmica do segmento agropecuário do território, que, mesmo de forma incipiente, contribui para os munícipes desse território e para o Estado da Bahia.

PALAVRAS-CHAVE: Desenvolvimento Regional; Bionegócios; Território de Identidade de Irecê. 


\section{INTRODUÇÃO}

Analisar a temática do desenvolvimento regional através de uma tríplice observação possível por meio da conceituação mais recente de bionegócios, desponta como fundamental para conceber a complexidade do ambiente e as relações socioeconômicas que são possíveis em determinado território. A ideia desse trabalho é fugir da superficialidade de análise meramente econômica, conseguindo abarcar a vertente socioambiental, gerando potencial de desenvolvimento regional. Tendo como viés principal a realização de um diagnóstico do Território de Identidade de Irecê, buscase identificar as potencialidades de desenvolvimento no campo da matriz produtiva de base agrícola.

A abordagem metodológica apresentada nesse artigo tem uma natureza exploratória. Acerca do seu âmbito teórico, o estudo apresenta a contribuição de diversos autores que vêm, paulatinamente, trabalhando na construção do conhecimento acerca da Teoria do Desenvolvimento Regional e do conceito de Bionegócios. Sob a ótica da análise de dados territoriais, observa-se que, a partir da comparação de indicadores da produção agrícola dos municípios que compõem o Território de Identidade de Irecê, coletados em órgãos de referência para o tema, tais como o IBGE, SEI, SDR, Ministério da Agricultura e outros, é possível realizar diversas inferências acerca do objeto de estudo, ou seja, a matriz produtiva agrícola.

Após uma coleta secundária de dados, contemplando os principais indicadores e variáveis de interesse na pesquisa, buscar-se-á estabelecer um comparativo entre os municípios, destacando aspectos de sua principal atividade econômica e o valor agregado desta para o Produto Interno Bruto - PIB municipal, além do impacto no PIB do território, referenciado na atividade produtiva do Estado da Bahia. Ao mesmo tempo, será elaborado um comparativo entre os aspectos econômicos e fatores sociais e ambientais para os mesmos municípios, ou seja, diferentes tipologias de bionegócios são evidenciadas e relacionadas no que se refere a matriz produtiva desses municípios. 0 universo da pesquisa contempla todos os municípios que compõem o Território de Identidade de Irecê.

Por fim, após a escolha do método para apresentação, análise e interpretação da teoria do desenvolvimento regional à luz do conceito de bionegócios e da matriz produtiva de base agrícola do Território de Identidade de Irecê, serão desenvolvidas técnicas de vinculação dessa teoria à prática já desenvolvida por esses municípios, 
sugerindo mecanismos para que os mesmos possam ampliar suas estratégias e potencializarem a produção regional.

Examinando os principais autores e pesquisadores sobre a temática do desenvolvimento regional, tanto no âmbito micro como macro, permeando por seus aspectos locais e suas interfaces com o ambiente global, além de considerar também o processo de inovação produtiva e o conceito de bionegócios, suas principais contribuições são direcionadas para a compreensão da cadeia produtiva agrícola, perfazendo o contexto econômico e socioambiental. Desse panorama descrito, finaliza-se com a apresentação de um diagnóstico voltado para o Território de Identidade de Irecê, o qual busca evidencias suas potencialidades econômicas e seu posicionamento enquanto unidade produtiva do Estado da Bahia.

\section{TEORIA DO DESENVOLVIMENTO REGIONAL}

Segundo Celso Furtado (1961, p. 149), “no mundo anterior a Revolução Industrial, o desenvolvimento econômico era, basicamente, um processo de aglutinação de pequenas unidades econômicas e de divisão geográfica do trabalho". Para esse mesmo autor, a classe comercial era considerada como a agente indutora desse processo e, a partir dessa classe observava-se o processo de concentração de capital financeiro. Diante dos escritos desse célebre autor, é possível perceber a trajetória delineada na história do pensamento econômico, por meio da qual surgem as ideias sobre desenvolvimento.

Apontando sua análise para a homogeneidade tecnológica na teoria desenvolvida por Celso Furtado, convém destacar as estruturas subdesenvolvidas, que foram objeto de análise durante muito tempo, sobretudo na década de 50 . Visando captar a essência dos problemas atuais das economias subdesenvolvidas, Furtado destacou aspectos importantes para compreensão das estruturas produtivas e sociais da época, sobretudo considerando o volume de mão de obra empregada e aquela que será necessária para que a economia se movimente, além do mais, a medida desses insumos necessária para que, de fato, uma determinada estrutura produtiva possa ser gerida. Ao mesmo tempo, complementou sua análise através da importância do pagamento de salários e incidência de impostos, empregados na operacionalização de determinada estrutura produtiva. Nesta análise ampla, dando dinamismo à economia, Furtado traçou o panorama da economia capitalista, bem como o papel do empresário e dos assalariados, como agentes indutores do processo de desenvolvimento. 
Historicamente o Brasil tem enfrentado diversas situações, pelas quais há a necessidade de aprofundamento nos estudos, principalmente aqueles que dão maior ênfase à problemática regional. Por outro lado, dos muitos dos estudos já existentes, referenciando o desenvolvimento regional do Nordeste brasileiro, tem-se a autoria de Celso Furtado. Por sua origem nordestina, sua trajetória intelectual e pessoal, como também o momento histórico em que viveu - o pós-Segunda Guerra Mundial, trouxe à tona a abordagem do problema do subdesenvolvimento e a desigualdade que atingia algumas regiões e se tornava evidente, sobretudo, na medida em que se fazia uma comparação entre territórios distintos. A tese de doutorado de Celso Furtado (1948) evidenciou um pouco da sua preocupação e entendimento do Brasil. A literatura a qual se debruçou converge com a "análise de sua formação histórica e dos condicionantes estruturais que essa herança havia deixado (FURTADO, 2001)".

Com relação a análise crítica de Celso Furtado no que tange as questões do Nordeste, é importante destacar e refletir alguns pontos que ajudam na compreensão do processo de desenvolvimento dos territórios, enquanto propulsores de uma agregação de saberes e práticas, as quais objetivam uma melhoria dos processos e, por fim, das condições de sustentação. Abarcar esta análise é o objetivo desse artigo e, para tal, entende-se que as bases de analise construídas por Celso Furtado permitem compreender a finalidade econômica de uma determinada região, como também os aspectos que são indissociáveis, dentre os quais, a vertente social e a sustentabilidade ambiental. Celso Furtado contesta, em sua obra, a ideia que muitos possuem, definindo o subdesenvolvimento como uma etapa preparatória para o desenvolvimento econômico. Sua abordagem evidencia que este subdesenvolvimento prescinde a uma formação histórico-estrutural particular, que pode ser transformado por meio de mudanças estruturais. Para o Nordeste, a alternativa prudente seria enveredar pelo processo de industrialização, através de progresso técnico, buscando assemelhar-se a regiões mais desenvolvidas.

A fim de auxiliar-nos na compreensão dos problemas ligados ao desenvolvimento e subdesenvolvimento, os mecanismos de desigualdade econômica nacionais e internacionais, seus aspectos locais e regionais, além das disparidades entre determinadas regiões no espaço geográfico, apoiamo-nos nas teorias do crescimento regional, no conceito de equilíbrio e desequilíbrio e ainda no conceito de causação cumulativa, baseado na teoria de Gunnar Myrdal (1957). 
O sentido da causação cumulativa abordado na obra de Myrdal (1957), não se vinculava imediatamente ao âmbito econômico, uma vez que seu estudo se fundamenta na problemática enfrentada pelos negros no EUA e no problema social envolviam mudanças circulares e cumulativas.

Tendo seu foco de pesquisa voltado aos problemas econômicos dos países subdesenvolvidos, Gunnar Myrdal, ainda na Universidade conheceu e apropriou-se do conceito de causação circular cumulativa através de uma palestra sobre reforma agrária e subdesenvolvimento. Com o passar do tempo, já como estudioso da economia dos países subdesenvolvidos, Myrdal (1957, p. 6),

percebeu a existência de um círculo vicioso do atraso e da pobreza, que poderia ser rompido pela aplicação planejada de reformas econômicas. Este movimento, no entanto, poderia ser também virtuoso: nada impedia que uma melhora econômica ou social condicionasse outra, e assim sucessivamente. (MYRDAL, 1957, p. 6).

Considerando seu estudo a partir de uma análise mais ampliada, percebe-se que a ideia principal de sua teoria foi desenvolvida a partir do conhecimento dos países subdesenvolvidos. A estrutura desses países é considerada desequilibrada, porém o objetivo a ser atingido é o desenvolvimento de tal região, mesmo que ancorado em um processo de industrialização desequilibrado. Esse processo de causação circular cumulativa se apresenta como a forma em que as mudanças ocorrem na sociedade. 0 desenvolvimento ocorre de maneira desigual em diversas regiões, mas isso pode produzir diversos efeitos, dentre os quais o favorecimento de uma certa economia em detrimento de outras. Ao mesmo tempo, de forma prática, a situação regressiva para um local pode gerar uma progressão em outra região, como o deslocamento populacional, o deslocamento técnico, o movimento de capitais, o comércio, entre outras atividades.

0 conceito que visa explicar a diferença entre regiões desenvolvidas e em desenvolvimento, na análise de Myrdal, é conhecido como a tese dos backwash effects (Myrdal, 1960). Torna-se evidente, a partir dessa análise que um determinado centro regional, a medida em que sofre a influência de um impulso econômico, tende a se desenvolver, ocorrendo uma perda de dinamismo em regiões do entorno. Esse movimento reverbera-se em diversos aspectos, sobretudo os econômicos, sociais e ambientais, influenciando nas variáveis como a migração, o movimento de capital e o comércio. Conforme destacam Oliveira e Attílio (2014, p. 38), 
os indivíduos buscariam os centros com maiores oportunidades de emprego e renda. Os investimentos, da mesma forma, fluiriam onde percebessem dinamismo econômico. Portanto, a expansão do comercio nas regiões mais avançadas teria como contrapartida a diminuição do comércio nas partes menos avançadas, o que aprofundaria a disparidade regional. Juntos, esses fatores alargariam o hiato entre regiões e países desenvolvido em relação aos em desenvolvimento. (OLIVEIRA; ATTÍLIO, 2014, p. 38).

É importante destacar nesse momento de observação que tanto Celso Furtado quanto Gunnar Myrdal oferecem uma análise dos fatores que envolvem o desenvolvimento, englobando uma proposta dinâmica e complementar. Não apenas os aspectos econômicos são determinantes, mas aspectos históricos e culturais ajudam a compreender e embasar os efeitos do desenvolvimento. A solução para os problemas estruturais encontra-se justamente na disponibilidade, articulação e formas de manejo dos fatores não-econômicos.

Corroborando com as observações acima, ampliando-se a um conceito de desenvolvimento espacial e economia política, referencia-se nessa análise, o Geógrafo Brasileiro, Baiano, Milton Santos, autor amplamente citado em estudo relativo aos processos de globalização e urbanização. No que tange a economia política, Santos (2009, p. 111) descreve no contexto das cidades, questões voltadas à produção, funcionamento do capital e do trabalho. No espaço geográfico, "a circulação dos produtos, das mercadorias, dos homens e das ideais ganhou uma expressão, dentro do processo global de produção, que a urbanização passou a ser um dado fundamental na compreensão da economia". (SANTOS, 2009, p. 113). É imprescindível para essa análise a compreensão de que a cidade se configura como um meio de produção material e imaterial e, sobretudo, utilizando-se das palavras desse célebre autor, um "nó de comunicação". (SANTOS, 2009, p. 114).

\section{CONCEITO DE BIONEGÓCIOS NO TI IRECÊ}

A análise de bionegócios, conceito este amplamente difundido em estudos oriundos da biodiversidade amazônica, permite-nos conceber a utilização de técnicas, desde as mais rudimentares àquelas mais elaboradas, visando abarcar atividades produtivas, alavancando o potencial econômico de determinada localidade. Conforme destacado, sua conceituação mais recente analisa atividades com a finalidade econômica, sendo aquelas que conseguem, além de tudo, abarcar uma vertente socioambiental, com foco na geração de desenvolvimento. Trabalhamos esse artigo como viés no Território de 
Identidade de Irecê, buscando-se identificar as potencialidades de desenvolvimento no campo da matriz produtiva de base agrícola, vinculadas à conceituação de bionegócios.

Para a análise que segue a partir de então, serão utilizados dois conceitos de bionegócios, já difundidos pela literatura da área. 0 primeiro conceito foi definido por Araújo Filho (2010, p. 9), evidenciando bionegócios como

\begin{abstract}
atividades com "fins econômicos", desenvolvidas por empresas, que tenham como principal característica o uso intensivo - e, portanto, significativa dependência - de insumos da biodiversidade. Para a perspectiva dessa formulação, não importa o grau de transformação sofrida por esse insumo, ou mesmo se alguma transformação ocorre. 0 que caracteriza o bionegócio é o uso significativo que um elemento da biodiversidade tenha em suas operações. Assim, mesmo atividades econômicas que exijam menor elaboração, como por exemplo a comercialização in natura de frutos regionais, estariam abrigados no conceito.
\end{abstract}

Diante desse conceito é possível apropriar-se de elementos que evidenciam muitas atividades econômicas, as quais dependem intensivamente do uso de insumos gerados a partir da biodiversidade. 0 autor confere e não faz distinção quanto ao grau de transformação sofrida pelos insumos, ou seja, mesmo atividades menos elaboradas, estão abarcadas pelo conceito de bionegócios. No momento da caracterização do Território de Identidade de Irecê, a abordagem desse artigo pretende classificar os municípios de acordo com as diferentes tipologias de bionegócios. A fim de compreender essas tipologias, sobretudo no que se refere ao beneficiamento dos produtos oriundos do Território de Identidade de Irecê, o autor se apropria do quadro abaixo, caracterizando os diferentes tipos de bionegócios existentes, por meio de uma classificação realizada em grupos, conforme descrito no Quadro 1:

Um segundo conceito imprescindível para a análise de bionegócios foi defendido por Juma e Konde (2001). Esses autores destacam que bionegócios são "atividades econômicas voltadas à extração/beneficiamento e comercialização de insumos ou produtos que apresentem na sua composição recursos da biodiversidade, sejam eles na sua forma mais bruta ou tecnologicamente modificada". 
Quadro 1: Caracterização das diferentes tipologias de bionegócios.

\begin{tabular}{|c|l|}
\hline $\begin{array}{c}\text { Tipologia de } \\
\text { bionegócios }\end{array}$ & $\begin{array}{l}\text { Características } \\
\text { Sso da biodiversidade no estado in natura ou submetida a processos de beneficiamento } \\
\text { simples, centrados em características mecânicas (cortar, polir, lixar, pintar, secar etc.); } \\
\text { inclui atividades com uso econômico do valor "cultural" da biodiversidade. São exemplos } \\
\text { de bionegócios classificáveis neste Grupo a comercialização de frutos e peixes frescos, } \\
\text { folhas, raízes, cascas, flores, artefatos com ênfase estética ou decorativa, moda, turismo. }\end{array}$ \\
\hline \multirow{6}{*}{ GRUPO II } & $\begin{array}{l}\text { Produtos que utilizam processos baseados em conhecimento consagrado, com domínio } \\
\text { disseminado (extração, concentração, filtração, destilação, separação etc.), que podem } \\
\text { demandar o uso de boas práticas (nas etapas de coleta, manuseio ou conservação, por } \\
\text { exemplo). Neste Grupo incluem-se produtos como bebidas, concentrados, doces, polpas, } \\
\text { pós. }\end{array}$ \\
\hline GRUPO III & $\begin{array}{l}\text { Abrange processos químicos e/ou biológicos de maior complexidade, cuja demanda por } \\
\text { conhecimento especializado implica em aumento de risco técnico; o desenvolvimento do } \\
\text { produto exige testes ou ensaios. Alcança matérias-primas e produtos de perfumaria, } \\
\text { cosméticos, fitoterápicos e fitocosméticos, bioenergia, reprodução de plantas, alimentos } \\
\text { industrializados. }\end{array}$ \\
\hline GRUPO IV & $\begin{array}{l}\text { A classificação neste Grupo é assegurada pelo uso de processos associados à chamada } \\
\text { biotecnologia moderna, que tem como base a biologia molecular e a engenharia genética } \\
\text { (ainda que outras características do bionegócio aqui classificado possam estar descritas } \\
\text { nos demais Grupos). Organismos geneticamente modificados, microorganismos } \\
\text { industrializados e alimentos funcionais são exemplos de produtos deste Grupo. }\end{array}$ \\
\hline
\end{tabular}
Fonte: Araújo Filho (2010)

Aprofundando os conceitos de bionegócios, a partir desses descrito acima inferese que, em se tratando do Território de Identidade de Irecê, com uma vasta geração de produtos oriundos da biodiversidade, uma primeira conjectura a ser feita está justamente em sua forma de apresentação, enquanto potencial de comercialização. Os produtos são apresentados de forma bruta, ou mesmo tecnicamente modificado, agregando-se valor. Esses aspectos serão evidenciados a partir do aprofundamento das características e do processo de regionalização existente nesse Território de Identidade.

\section{POTENCIALIDADES DO TI IRECÊ}

A etapa seguinte apresenta-se com o intuito de realizar a caracterização do Território de Identidade de Irecê, destacado seus aspectos socioeconômicos e de sustentabilidade. 0 conceito de Territórios de Identidade tem como origem as necessidades de diferenciação de regiões e aprofundamento de características semelhantes, realizado pelo Ministério do Desenvolvimento Agrícola (MDA).

Considerando a regionalização adotada pela Superintendência de Estudos Econômicos e Sociais da Bahia (SEI) e pelo Instituto Brasileiro de Geografia e Estatística (IBGE), o Território de Identidade de Irecê encontra-se estabelecido no Centro-Norte do Estado da Bahia, ocupando uma extensão territorial de $26.638 \mathrm{~km}^{2}$, correspondendo a 4,7\% do Estado (IBGE, 2013). Abrange 20 (vinte) municípios, sendo os seguintes: 
América Dourada, Barra do Mendes, Barro Alto, Cafarnaum, Canarana, Central, Gentio do Ouro, Ibipeba, Ibititá, Ipupiaa, Irecê, Itaguaçu da Bahia, João Dourado, Jussara, Lapão, Mulungu do Morro, Presidente Dutra, São Gabriel, Uibaí e Xique-Xique (SEI, 2018). 0 perfil desse território, de acordo com a SEI (2018, p. 141), destaca que esses municípios fazem parte da área de abrangência do Semiárido. Dessa forma, predomina-se "o clima semiárido, com precipitação em torno dos $750 \mathrm{~mm}$, com chuvas de primavera/ verão. A temperatura média fica em torno dos 23,7 ㄷ‥ (SEI 2018, p. 141). A bacia hidrográfica do São Francisco insere, quase em sua totalidade, os municípios desse território e a vegetação predominante é formada por "Remanescentes de Caatinga Arbórea e Contato Caatinga-Floresta Estacional. A Floresta de Galeria ocorre nas várzeas e terraços do Rio São Francisco. Há também áreas de Refúgio Ecológico nas serras em Gentio do Ouro e Ipupiara". (SEI, 2018, p. 141).

O processo evolutivo do Território de Identidade de Irecê envolve não apenas aspetos econômicos. Sua formação histórica e especificidade dentro do Estado Bahia auxiliam um amplo entendimento a respeito da sua configuração, que perpassa pela análise econômica, social e de sustentabilidade. Esse artigo utiliza-se desse tripé para implementar conceitos de bionegócios no referido território. No tocante às potencialidades vinculadas a esse conceito, aproxima-se de estudos já realizados pela SEI e IBGE, os quais conseguem traçar um panorama, além de alertar potencialidades de expansão e exploração, sobre as quais vê-se que, de maneira heterogênea, os municípios desse território têm se apropriado.

A divisão do Estado em Territórios de Identidade diferencia-se daquela apresentada pelo IBGE, uma vez que consegue abarcar no mesmo um estímulo ao desenvolvimento econômico, atrelado com o protagonismo das forças locais. Concordando com Duarte (2009, p. 3), no que tange ao protagonismo dos Territórios de Identidade, vê-se que eles garantem uma efetiva

interação que propiciam entre os diversos segmentos sociais - entidades representativas da sociedade civil, poderes municipais, estaduais e federais, cooperativas e associações, permitindo que estes compartilhem como visão de futuro para o território, o princípio segundo o qual o desenvolvimento é o aumento da capacidade de os indivíduos fazerem escolhas. A capacidade de o território transformar-se em território - projeto, constitui a base de uma nova relação entre os atores locais e o Estado, a partir da organização local e da constituição de um pacto de coesão social que conduza a contratos de desenvolvimento das potencialidades locais e não mais à mera transferência de recursos para ações absolutamente desvinculada das características e identidades do território. (DUARTE, 2009, P. 3). 
Duarte (2019) evidencia, sob vários aspectos, sobretudo no que diz respeito à capacidade de planejamento e ações coordenadas primordialmente pelos atores locais, aquilo que a Secretaria do Planejamento do Estado da Bahia, em 2017 utilizou como parâmetros de análise. Ressalta-se que os territórios se constituem como unidades de planejamento para as políticas públicas do Estado. Dentre outros aspectos, a referida secretaria enxerga essa regionalização como a mais coerente no sentido de "possibilitar o planejamento das ações de desenvolvimento do Estado, de acordo com as demandas características da população de cada região, que são representadas por órgãos da sociedade civil organizada, levando-se em consideração aspectos sociais, econômicos e culturais". (SEPLAN, 2007).

\subsection{ESPECIFICIDADE DO TI IRECÊ}

O perfil do Território de Identidade de Irecê pode ser delineado a partir de aspectos, pelos quais associa-se ao conceito de bionegócios, o qual foi inicialmente estudado no fomento da bioeconomia, e são eles: aspectos socioeconômicos e condições de sustentabilidade.

O Território de Identidade de Irecê é bastante heterogêneo e historicamente observa-se que seu potencial de desenvolvimento vincula-se basicamente a população que se formou nessas cidades, como também, pelo enfrentamento às condições mais adversas. Analisando os pressupostos históricos desse território, de acordo com a SEI (2018, p. 147), “o primeiro município a ser criado foi Xique-Xique, desmembrado de Sento Sé (TI Sertão do São Francisco) em 1832, que recebeu esse nome devido à grande quantidade de uma espécie de cacto popularmente conhecido como xique-xique". Em seguida surgiu Gentio do Ouro (exploração de ouro e diamantes).

Segundo o IBGE, através de dados estimados de 2018, a população do Território de Identidade de Irecê é formada por 442.134 habitantes. Ao mesmo tempo, considerando o Censo Demográfico 2010, há nesse território 402.828 habitantes, ou seja, estimativamente observa-se uma taxa de crescimento de 9,76\%. A tabela 1 abaixo apresenta a população dos municípios do TI Irecê, considerando a estimativa do IBGE em 2018. 
Tabela 1: População estimada do território de identidade de irecê 2018.

\begin{tabular}{|c|c|c|}
\hline Municípios & $\begin{array}{c}\text { População Estimada } \\
2018 \text { (hab.) }\end{array}$ & $\%$ \\
\hline América Dourada & 16.097 & $3,81 \%$ \\
\hline Barra do Mendes & 13.900 & $3,29 \%$ \\
\hline Barro Alto & 14.802 & $3,51 \%$ \\
\hline Cafarnaum & 18.356 & $4,35 \%$ \\
\hline Canarana & 26.020 & $6,16 \%$ \\
\hline Central & 17.252 & $4,09 \%$ \\
\hline Gentio do Ouro & 11.206 & $2,65 \%$ \\
\hline Ibipeba & 18.097 & $4,29 \%$ \\
\hline Ibititá & 17.150 & $4,06 \%$ \\
\hline Ipupiara & 9.817 & $2,33 \%$ \\
\hline Irecê & 72.386 & $17,15 \%$ \\
\hline Itaguaçu da Bahia & 14.311 & $3,39 \%$ \\
\hline João Dourado & 24.946 & $5,91 \%$ \\
\hline Jussara & 15.307 & $3,63 \%$ \\
\hline Lapão & 27.170 & $6,44 \%$ \\
\hline Mulungu do Morro & 11.114 & $2,63 \%$ \\
\hline Presidente Dutra & 15.121 & $3,58 \%$ \\
\hline São Gabriel & 18.798 & $4,45 \%$ \\
\hline Uibaí & 13.884 & $3,29 \%$ \\
\hline Xique-Xique & 46.400 & $10,99 \%$ \\
\hline TOTAL & 422.134 & $100,00 \%$ \\
\hline
\end{tabular}

Fonte: IBGE 2018 (Adaptado).

A distribuição dessa população em zona urbana e rural se dá da seguinte forma: $61,4 \%$ residentes na zona urbana e 38,6\% na zona rural. Esse percentual de pessoas no meio urbano é inferior ao verificado no Estado da Bahia, que atinge 72,1\%. Dessa forma, de acordo com a regionalização em Territórios de Identidade, o de Irecê é caracterizado como pouco urbanizado.

O Produto Interno Bruto (PIB) impõe-se como uma variável fundamental nesse estudo, sob a qual permeia a análise de bionégocios desse território. Com a finalidade de atingir-se os pressupostos do estudo de desenvolvimento regional, na perspectiva de cadeias produtivas, compreender o comportamento da produção por município do TI de Irecê é o aspecto mais relevante. Dessa forma foram realizadas pesquisas bibliográficas, bem como a coleta de dados secundários através do IBGE e da SEI. A mais recente desagregação desses dados a nível de território para o PIB e valor adicionado dos setores agropecuário, industrial e de serviços foi localizado no ano de 2017. Além dessas informações, segmentadas por municípios do Território de Identidade de Irecê, é 
possível verificar o valor adicionado incluindo a Administração Pública, como também a incidência de impostos sobre produtos, desagregado por município, no ano de 2017. Essas informações podem ser analisadas na tabela abaixo.

Tabela 2: PIB municipal, valor adicionado, PIB e PIB per capita a preços correntes Território de Identidade de Irecê - 2017.

\begin{tabular}{|c|c|c|c|c|c|c|c|}
\hline \multirow[b]{2}{*}{ Municípios } & \multicolumn{3}{|c|}{ Valor Adicionado (R\$ milhões) } & \multirow{2}{*}{$\begin{array}{c}\text { Valor } \\
\text { Adicionado } \\
\text { APU } \\
\text { (R\$ milhões) }\end{array}$} & \multirow{2}{*}{$\begin{array}{c}\text { Impostos } \\
\text { Sobre } \\
\text { Produtos } \\
\text { (R\$ milhões) }\end{array}$} & \multirow{2}{*}{$\begin{array}{c}\text { PIB } \\
\text { (R\$ } \\
\text { milhões) }\end{array}$} & \multirow{2}{*}{$\begin{array}{l}\text { PIB Per } \\
\text { Capita } \\
\text {-R } \$ 1,00\end{array}$} \\
\hline & Agropecuária & Indústria & $\begin{array}{l}\text { Serviços } \\
\text { (1) }\end{array}$ & & & & \\
\hline $\begin{array}{l}\text { América } \\
\text { Dourada }\end{array}$ & 16,2 & 7,55 & 81,24 & 52,17 & 6,25 & 111,23 & $6.621,81$ \\
\hline $\begin{array}{l}\text { Barra do } \\
\text { Mendes }\end{array}$ & 6,03 & 4,42 & 80,47 & 43,73 & 3,29 & 94,21 & $6.470,50$ \\
\hline Barro Alto & 6,88 & 4,06 & 69,82 & 46,13 & 3,83 & 84,59 & $5.558,82$ \\
\hline Cafarnaum & 12,68 & 23,06 & 113,22 & 65 & 10,46 & 159,41 & $8.387,58$ \\
\hline Canarana & 19,24 & 10,2 & 143,88 & 83,38 & 9,73 & 183,05 & $6.814,58$ \\
\hline Central & 5,43 & 40,53 & 120,2 & 59,53 & 13,47 & 179,63 & $9.996,63$ \\
\hline $\begin{array}{l}\text { Gentio do } \\
\text { Ouro }\end{array}$ & 4,04 & 63,83 & 63,34 & 39,41 & 12,93 & 144,15 & $12.385,07$ \\
\hline Ibipeba & 18,03 & 10,03 & 87,24 & 54,49 & 8,15 & 123,45 & $6.609,47$ \\
\hline Ibititá & 15,59 & 8,52 & 85,69 & 53,81 & 7,39 & 117,2 & $6.529,85$ \\
\hline Ipupiara & 4,1 & 7,43 & 61,77 & 30,29 & 4,39 & 77,7 & $7.649,51$ \\
\hline Irecê & 19,87 & 97,67 & 843,81 & 220,78 & 119,54 & $1.080,88$ & $14.511,79$ \\
\hline $\begin{array}{l}\text { Itaguaçu da } \\
\text { Bahia }\end{array}$ & 8,8 & 5,94 & 69,73 & 48,52 & 12,72 & 97,19 & $6.603,64$ \\
\hline $\begin{array}{l}\text { João } \\
\text { Dourado }\end{array}$ & 18,42 & 14,9 & 161,09 & 85,78 & 14,39 & 208,81 & $8.141,93$ \\
\hline Jussara & 6,41 & 4,96 & 82,8 & 52,84 & 3,83 & 98,01 & $6.123,20$ \\
\hline Lapão & 20,57 & 18,23 & 141,01 & 84,57 & 11,9 & 191,71 & $6.787,59$ \\
\hline $\begin{array}{l}\text { Mulungu do } \\
\text { Morro }\end{array}$ & 7,94 & 4,53 & 66,48 & 42,99 & 12,89 & 91,84 & $7.660,77$ \\
\hline $\begin{array}{l}\text { Presidente } \\
\text { Dutra }\end{array}$ & 8,12 & 7,37 & 81,7 & 48,25 & 3,97 & 101,16 & $6.429,46$ \\
\hline São Gabriel & 5,31 & 6,29 & 94,01 & 63,47 & 4,04 & 109,65 & $5.590,49$ \\
\hline Uibaí & 9,84 & 5,3 & 71,5 & 45,24 & 3,19 & 89,85 & $6.207,38$ \\
\hline Xique-Xique & 48,86 & 13,93 & 289,71 & 159,79 & 16,82 & 369,32 & $7.636,14$ \\
\hline TOTAL & 262,35 & 358,76 & $2.808,72$ & $1.380,17$ & 283,2 & $3.713,03$ & $152.716,21$ \\
\hline
\end{tabular}

Fonte: SEI / IBGE (Adaptado).

Considerando-se os dados do SEI/IBGE para o ano de 2017, os maiores municípios em termos de PIB foram: Irecê (R\$ 1.080,88 milhões) e Xique-Xique (R\$ 369,32 milhões). Os menores em relação ao PIB foram: Ipupiara (R \$ 77,70 milhões), Barro Alto (R\$ 84,59 milhões), Uibaí (R\$ 89,85 milhões) e Mulungu do Morro (R 91,84 milhões). Esses quatro últimos, com reduzido VAB, tinham uma elevada participação da administração pública na composição do PIB, sendo, portanto, Ipupiara um dos menores em dinamismo econômico e o maior em dependência das transferências de fundos municipais, como o FPM, para financiamento de serviços públicos. 
Analisando-se a dinâmica do valor adicionado, desagregando os setores em agropecuária, industrial e de serviços, observa-se que uma vez incluída a Administração Pública, haja visto situar-se com indutora da geração de emprego e renda, sobretudo nas pequenas cidades do território, as quais não desenvolveram outras estratégias de dinamismo a atividade econômica, o setor de serviços abarca 81,89\% do valor adicionado, no ano de 2017. Em seguida a indústria e a agropecuária atingem, respectivamente, os percentuais de 10,46\% e 7,65\%. Embora não se apresenta com um alto valor agregado no total do território, o setor industrial de Irecê $(27,22 \%)$ e de Gentio do Ouro $(17,79 \%)$ tiveram uma relativa participação no VAB municipal.

Com uma parcela significativa de sua população ainda vivendo no estrato rural, o VAB agropecuário do TI Irecê apresentou participação significativa no PIB de 2017.

Ainda de acordo com a tabela acima, analisando-se o dinamismo do setor agropecuário, do total de 20 municípios do território, em 2017, 9 deles obtiveram um valor adicionado superior a 10 milhões de reais. Merece destaque o município de XiqueXique, onde o segmento agropecuário representou 18,62\% de toda riqueza produzida no TI Irecê. Seguido do município de Xique-Xique, observa-se Lapão (7,84\%). Em oposição, a menor dinâmica agropecuária observa-se nos municípios de Gentio do Ouro e Ipupiara, atingido respectivamente $1,54 \%$ e $1,56 \%$.

0 mapa rodoviário do TI tem a BA-052 como a principal rodovia. Popularmente conhecida como Estrada do Feijão, devido à importância no escoamento da produção deste grão durante os anos 1990, a BA-052 liga Feira de Santana (a partir do entroncamento com a BR-116) e, consequentemente, Salvador (via BR-324) ao município de Xique-Xique, passando por Irecê, América Dourada, João Dourado e Central, servindo de acesso aos ramais estaduais que interligam os demais municípios do território. Exceto Mulungu do Morro e Cafarnaum, que são acessados pela BR-122 a partir de um entroncamento com a BR-242, os municípios restantes têm acesso por rodovias estaduais: Jussara e São Gabriel (BA-148), Presidente Dutra e Uibaí (BA-225), Canarana e Lapão (BA-432), Barra do Mendes, Ibititá e Ibipeba (BA-148), Barro Alto (BA-048) e Ipupiara (BR-158 a partir do entroncamento com a BR-242). Na estrutura viária, apenas rodovias atendem ao TI Irecê, que não é servido por aeroporto ou ferrovias.

Se relacionados à tipologia dos bionegócios apresentada no capítulo anterior, percebe-se que a produção dos municípios pesquisados se enquadra basicamente no 
Grupo I, ou seja, no estado in natura ou submetida a processos de beneficiamento simples, centrados em características mecânicas. Essa classificação justifica-se por se tratar de uma produção basicamente cultivada e escoada aos mercados consumidores. Mesmo em escalas diferentes, o manejo da produção apresenta características similares. Observa-se que há um domínio tecnológico também semelhante, porém, destacando nessa análise os municípios de Irecê, Xique Xique, João Dourado, Lapão e Canarana, em virtude do seu porte - seja em aspecto, populacional, quanto em valor agregado.

A bibliografia disponível leva-nos ainda a uma constatação de que esse território não contempla lavouras permanentes significativas em relação ao total da Bahia. Contudo, vale destacar, entre outras, a produção de banana, destacando como predominante, no município de Ibipeba.

Em 2018, a SEI, com a finalidade de traçar um perfil dos territórios da Bahia, realizou um estudo considerando a lavoura temporária do Território de Identidade de Irecê. Utilizando dados de 2015, a participação dessa lavoura temporária para o Estado da Bahia atendia a seguinte composição: "mamona (74,9\% da produção do estado), tomate $(27,1 \%)$ e cebola (19,0\%)". (SEI, 2018, p. 150). Ainda nesse estudo, os municípios do TI Irecê, considerados mais relevantes na produção de lavouras temporárias são: “Cafarnaum (11,3\% do total produzido no TI de cebola e 41,0\% de tomate), João Dourado (23,4\% de cebola e 13,7\% de tomate) e Lapão (10,0\% de cebola e 12,0\% de tomate)". (SEI, 2018, p. 150). Destacando o cultivo de mamona, este se destina à produção de biodiesel e esse território se apresenta por meio da maior participação no estado. Essa produção está disseminada entre quase todos os municípios, merecendo “destaques para São Gabriel (16,6\% da produção total), Ibititá $(14,8 \%)$ e Presidente Dutra (13,3\%)". (SEI, 2018, p. 150).

Por fim, utilizando-se dessa contribuição para delinear o perfil do Território de Identidade de Irecê, ainda no estudo realizado pela SEI, no tocante a pecuária, "os principais efetivos de rebanhos, com as respectivas participações no estado, foram suínos (6,4\%), ovinos (5,6\%) e caprinos (4,4\%)". (SEI, 2018, p. 151). Destacando os municípios que apresentaram relevância nessas criações, temos os seguintes: "XiqueXique $(15,3 \%$ de suínos, $14,3 \%$ de ovinos e 25,3\% de caprinos) e Jussara (20,1\% de caprinos e 12,6\% de ovinos)". (SEI, 2018, p. 151). 


\section{CONSIDERAÇÕES FINAIS}

Diante de todo o exposto, percebe-se que a intenção desse artigo é aprofundar a temática do desenvolvimento regional, atrelado a um contexto que contempla a abordagem econômica e aspectos sociais e ambientais, partindo do diagnóstico do Território de Identidade de Irecê. 0 objetivo é identificar as potencialidades de desenvolvimento da matriz produtiva de base agrícola dessa região.

Por meio da contemplação de dados do IBGE, da SEI, entre outros, foi possível conhecer a composição dos municípios do TI Irecê, qualificando-os quanto a tipologia de Bionegócios e certificando-se de que maior parte desses municípios que compõem o território apresenta características similares, dentre elas, baixo nível de urbanização; nível intermediário de desenvolvimento humano; proeminência dos municípios de Irecê e Xique-Xique, no aspecto territorial; elevada participação de pessoas ocupadas na produção para o próprio consumo; equilíbrio das atividades econômicas na geração de riquezas. Pertencem a tipologia do grupo I. O perfil socioeconômico similar dá ao Território de Identidade um comportamento de homogeneidade, facilitando na definição de políticas públicas que fomentam a atividade produtiva no Irecê baiano. Milton Santos, em sua obra, analisa a economia política das cidades, afirmando que o espaço geográfico é totalmente dependente da distribuição de fatores de produção e instrumentos de trabalho. Isso ficou evidenciado na distribuição dos meios produtivos desse TI.

Apropriando-se conceitualmente de autores referência no âmbito do Desenvolvimento Regional, dentre eles Celso Furtado e Gunnar Myrdal, bem como do conceito mais recente relativo a bionegócios, é possível concluir que, para o Território de Identidade de Irecê, há uma carência no desenvolvimento de políticas públicas voltadas à sustentação das potencialidades em alguns setores, sobretudo no segmento industrial e no agropecuário. Muitas iniciativas são observadas no mais diversos municípios que compõem o TI e estas estão atreladas a aspectos históricos, culturais, ao sentimento de pertencimento, à valorização da sustentabilidade, porém, estamos tratando de um território importante no Estado, que ainda dispõe de muito potencial de expansão. Conforme reafirma Celso Furtado, a condição de subdesenvolvimento pode despontar como vetor para o desenvolvimento. 


\section{REFERÊNCIAS}

[1] ARAÚJO FILHO, G. Iniciativas em Bionegócios e o Programa PAPPE Subvenção no Estado do Amazonas. Revista T\&C Amazônia, Ano VIII, n. 19, 2010.

[2] COSTA, Francileide P.; SAMPAIO, José Roberto Tavares; CARNEIRO; Mônica Pollyanna Sales Rios; LOPES, Jerisnaldo Matos. Bionegócios no Nordeste: A produção agrícola, suas potencialidades e desafios. Revista Diálogos \& Ciências. Ano 16, no 36, junho 2016.

[3] DUARTE, José Carlos Silveira. Territórios de Identidade e Multiterritorialidade: Paradigmas para a formulação de uma nova regionalização da Bahia. V ENECULT - Encontro de Estudos Multidisciplinares em Cultura. Faculdade de Comunicação/UFBa, Salvador/Ba, 2009.

[4] FURTADO, Celso. Desenvolvimento e Subdesenvolvimento. Rio de Janeiro, Fundo de Cultura, 1961.

[5] FURTADO, C. A economia colonial brasileira nos séculos XV e XVII. São Paulo: Hucitec, 2001.

[6] InSTITUTO BRASILEIRO DE GEOGRAFIA E ESTATÍSTICA (IBGE). Cidades. Disponível em: https://cidades.ibge.gov.br/brasil/ba/irece/panorama. Acesso em: 30.04.2020.

[7] JUMA, C.; KONDE, V. The New Bioeconomy: Industrial and Enviroment Biotechnology in Developing Countries. Genebra, United Nations Conference on Trade and Development (UNCTAD), 15 - 16 nov. 2001.

[8] MINISTÉRIO DO DESENVOLVIMENTO AGRÁRIO (MDA). Território de Irecê: Plano Territorial de Desenvolvimento Rural Sustentável - PTDRS. MDA, Brasília/DF. 2010.

[9] MYRDAL, Gunnar. Aspectos Políticos da Teoria Econômica. Ed. Nova Cultural. São Paulo/SP, 1957.

[10] OlIVEIRA, T. D.; ATTÍliO, L. A. Causação cumulativa em Myrdal e seus desdobramentos enquanto alternativas ao conceito de equilíbrio. Revista de Economia, v. 40, n. 3 (ano 38), p. 28-46, set./dez.2014. Disponível em: https://revistas.ufpr.br/economia/article/view/39584. Acesso em: 21.04. 2020.

[11] SANTOS, Milton. Por uma Economia Política da Cidade: 0 caso de São Paulo. Editora da Universidade de São Paulo, 2ª ed. São Paulo, 2009.

[12] SUPERINTENDÊNCIA DE ESTUDOS ECONÔMICOS E SOCIAIS DA BAHIA (SEI). Perfil dos Territórios de Identidade. v. 3. Salvador: SEI, 2018. p. 252. Série Territórios de Identidade da Bahia. 


\section{Capítulo 6}

Implantação do parque eólico no município de Morro do Chapéu: Uma análise dos aspectos ambientais, sociais e econômicos

Tácio Reis Dias Pereira Valois

Livia da Silva Modesto Rodrigues 
RESUMO: Esse artigo analisou de que maneira os empreendimentos de geração de energia elétrica através de fonte eólica impactaram no âmbito social, ambiental e econômico no processo de implantação dos parques eólicos no município de Morro do Chapéu, cidade localizada no semiárido baiano, a qual vem passando por algumas transformações mediante exploração da atividade eólica. 0 trabalho fundamenta-se na Contabilidade Socioambiental, bem como trouxe conceitos de desenvolvimento sustentável, abordando a temática de energias renováveis sob o enfoque da Energia Eólica, além de trazer os aspectos socioeconômicos que tratam da cidade a qual serviu como o objeto de estudo. A pesquisa é descritiva, documental, bibliográfica, exploratória por meio de estudo de caso no município de Morro do Chapéu com base no Relatório de Impactos Ambientais disponibilizados pela Biodinâmica Engenharia e Meio Ambiente sobre o Complexo Eólico Serra da Babilônia. 0 estudo conclui que se faz necessária uma transparência das contas públicas mais abrangentes e elucidativas e enaltece a importância dos relatórios de impactos ambientais para o entendimento dos efeitos no meio ambiente.

PALAVRAS-CHAVE: Energia Eólica; Sustentabilidade; Contabilidade Socioambiental; Estudos de Impactos Ambientais. 


\section{INTRODUÇÃO}

O empenho para o desenvolvimento de energias renováveis tem sido ampliado em virtude do esgotamento de fontes de energia às quais não são renováveis, a exemplo das fontes fósseis e que é caracterizada como altamente poluente. Não basta desenvolver-se economicamente a qualquer custo. É necessário pensar maneiras alternativas para que se possam estabelecer medidas ao avanço da economia, havendo espaço para o crescimento simultâneo das comunidades e todos aqueles que ali estão inseridos. Nesse sentido, outra preocupação que não pode ser deixado de lado, pois, além dos benefícios sociais para a comunidade, tem que haver um cuidado especial com os aspectos ambientais existentes onde a atividade econômica está sendo desenvolvida.

Dentre os diversos temas relacionados à questão socioambiental, a sustentabilidade tem sido objeto de discussão em variados ramos do conhecimento da ciência, no meio empresarial, envolvendo a indústria, comércio e serviços. Em se tratando de Ciência Contábil, essa questão foi introduzida e amplamente discutida nos últimos anos em função da abordagem qualitativa da contabilidade socioambiental e recebido grande notoriedade, uma vez que de variadas maneiras a sociedade tem pressionado as empresas a observarem pontos vitais no que tange a sustentabilidade do negócio, demandando a devida observância de padrões de conduta e ética compatíveis com o desenvolvimento sustentável.

A não observância dessa relevante questão, ou ainda, a ineficiência de mecanismos utilizados com o fim de mitigar os impactos socioambientais provocados pela atividade empresarial pode desencadear impactos econômico-financeiros e ambientais que comprometem a continuidade da empresa quando não são devidamente analisados os reflexos sobre o patrimônio da entidade.

Nesse contexto, o Nordeste, de maneira geral, é privilegiado por sua diversidade geográfica. É sabido por todos que a região também enfrenta grandes problemas de escassez hídrica em sua maior parte, em especial o semiárido. Apesar disso apresenta um potencial enorme para o desenvolvimento de energia por fonte renovável, podendo citar, sobretudo, a energia eólica, a qual este trabalho propôs discorrer.

Este trabalho abordou sobre os impactos gerados com a exploração da energia eólica no município de Morro do Chapéu (BA), considerando a implantação do Complexo Eólico-Solar Serra da Babilônia, mediante a análise do Relatório de Impactos Ambientais (RIMA, 2018) e nos dados dos órgãos de pesquisa socioeconômicas do Instituto 
Brasileiro de Geografia e Estatística (IBGE) e Superintendência de Estudos Socioeconômicos da Bahia (SEI).

Conforme a Constituição Federal, Art. 159, I, b, Emenda Constitucional nº8 de 2015, o Fundo de Participação dos Municípios - FPM é constituído pela arrecadação dos impostos sobre renda e proventos de qualquer natureza e sobre produtos industrializados, aplicando-se 22,5\% ao FPM, onde a distribuição dos recursos é feita de acordo com o número de habitantes. Como se apresenta a maioria dos municípios brasileiros, no Estado da Bahia, mais especificamente no Território Identidade Chapada Diamantina, perpassam por uma grande dependência fiscal das transferências do governo federal, principalmente FPM e FUNDEB.

Desta maneira, a exploração da atividade eólica é uma alternativa interessante para que o município possa aumentar suas arrecadações, além de movimentar a economia da região, proporcionando geração de novos empregos, oportunidades de arrendamentos de áreas rurais para as instalações dos parques aumentam, novos prestadores de serviços surgem, dentre outros impactos positivos incidentes sobre a implantação da atividade eólica.

Portanto, o tema proposto é oportuno para aprofundar a pesquisa e compreender o desenvolvimento econômico e social, bem como os impactos ambientais a partir da implantação dos parques eólicos no município de Morro do Chapéu. Desta maneira, apresenta-se como objetivo geral deste trabalho evidenciar os efeitos econômicos e sociais atingidos durante o processo de implantação e geração de energia eólica a partir da implantação do parque eólico na cidade de Morro do Chapéu. Para isso, têm-se como objetivos específicos discorrer sobre a Contabilidade Socioambiental; caracterizar a energia limpa com o enfoque na energia eólica; e apresentar os impactos econômico, social e ambiental da atividade eólica no município com propósito de destacar impactos na melhoria da arrecadação pública municipal.

A pesquisa se justifica pela óptica científica, visto a tendência de crescimento do setor energético, mais especificamente ao se tratar de fontes limpas, energias renováveis, permitindo conhecer a contribuição que o setor pode oferecer, merecendo atenção maior no meio científico, já que pesquisas envolvendo a temática podem ser bem mais exploradas. Torna-se mais interessante quando um trabalho científico possa contribuir diretamente à comunidade em que é realizado o estudo. 


\section{REFERENCIAL TEÓRICO}

\subsection{CONTABILIDADE SOCIOAMBIENTAL \\ 2.1.1 CONTABILIDADE SOCIAL}

A contabilidade como um grande sistema de informação tem o compromisso com a transparência, a qual se preocupa em repassar informações financeiras, econômicas, sociais e ambientais, podendo ser de natureza monetária e não monetária.

Na última década, têm-se observado iniciativas no mundo todo, inclusive no Brasil, para que dados de natureza social venham a se tornar públicos, apresentados por meio de relatórios específicos, onde são evidenciados os investimentos realizados e programas de controle, preservação e proteção na área ambiental, e aos recursos aplicados em benefício da comunidade.

Para o alcance do desenvolvimento econômico, sem que haja a devida atenção ao social, torna-se desumano e provoca exclusão social e impactos ambientais. Via de regra, as organizações empresariais tem como objetivo a lucratividade, onde busca aperfeiçoar sua produtividade a fim de prolongar a continuidade das atividades, bem como maior eficiência do retorno do capital aportado no empreendimento, refletindo, desta maneira, o princípio da continuidade.

\subsubsection{CONTABILIDADE AMBIENTAL}

É importante enfatizar, atualmente, a crescente preocupação das organizações em causas relacionadas à preservação do meio ambiente, ainda que algumas sejam para estabelecer uma boa relação com os consumidores, não passando por mera ação midiática. Independente da motivação, a tendência é que se amplie a discussão do desenvolvimento sustentável, onde se conceitua crescer economicamente, garantindo a preservação do meio ambiente e o desenvolvimento social para o presente e gerações futuras.

Para Braga (2007), o desenvolvimento sustentável está apoiado em três pilares:

a) capital social: emprego e renda para gerar cidadania através de uma cadeia produtiva agregativa e includente que permita o crescimento econômico local;

b) retorno econômico: que beneficie todos os stakeholders, principalmente investimento em ciência e tecnologia que permita produzir mais com menor quantidade de matéria-prima e que reduz o volume de resíduos; e

c) respeito ao meio ambiente: gestão ambiental na entidade para impedir impactos negativos para a sociedade e o meio ambiente.

Nesse contexto, as empresas têm papel fundamental já que possuem recursos financeiros e podem fazer a transferência desse capital social com mais eficiência e estão 
mais habituados a atingir metas, havendo menos burocracia. As empresas podem atuar de forma socialmente responsável, minimizando e eliminando impactos ambientais. Da mesma maneira que podem gerar impactos negativos, podem trazer também benefícios à comunidade se tiver um sistema de gestão eficaz.

Na contabilidade ambiental, um dos aspectos que gera discussões se dá pela mensuração do patrimônio ambiental para que possa valorar os recursos naturais existentes. $\mathrm{Na}$ visão da contabilidade, o que se pode mensurar são as transações econômico-financeiras que refletem a interação da empresa com o meio ambiente, considerando a diversidade de fontes de energia, suas vantagens e desvantagens perante a necessidade de geração de energia limpa.

\subsection{ENERGIA RENOVÁVEL}

Diante de todo desenvolvimento que a sociedade sofreu, a exemplo de guerras com grandes prejuízos por todo o mundo em busca de poder, crescimento populacional desenfreado, revoluções industriais e tecnológicas, novas demandas por reservas energéticas, dentre outros processos, chegamos ao século XXI com boas expectativas para o setor energético.

Sabemos que, para o desenvolvimento econômico de um país acontecer, as matrizes energéticas desempenha papel fundamental nesse aspecto. Dependemos da energia para manter as indústrias ativas, para manter o transporte de cargas e pessoas, levar eletricidade para as empresas, para as residências e para a agropecuária. A matriz energética é facilmente confundida com a matriz elétrica, mas são coisas diferentes. Matriz energética é o conjunto de fontes de energia, a qual a matriz elétrica é uma delas, sendo formada pelo conjunto de fontes disponíveis apenas para a geração de energia elétrica.

\subsubsection{MATRIZ ENERGÉTICA}

Em 2016, uma escala global, de acordo com a Empresa de Pesquisa Energética EPE, a predominância da matriz energética é de energia não renovável. Em destaque temos o petróleo e seus derivados compondo 31,9\% das matrizes, seguido do carvão com $27,1 \%$, o gás natural com 22,1\% e a nuclear com 4,9\%. 0 restante é composto por fontes renováveis com destaque para biomassa, com 9,8\%. Fontes renováveis como eólica; solar e geotérmica compõem apenas 1,6\%. Desta maneira, restam 2,5\% para 
hidráulica.

No Brasil, esse quadro muda bastante, já que a matriz energética é composta por 42,9\% de fontes renováveis conforme a publicação do Balanço Energético Nacional (BNE) 2018, ano base 2017, pela EPE. Ou seja, representa quase metade de nossa matriz energética. Esses dados estatísticos se tornam importante mediante o debate do desenvolvimento sustentável, levando o país ao crescimento movido por fontes de energia renováveis, encadeando a diminuição de emissão de gases de efeito estufa (GEE).

\subsubsection{MATRIZ ELÉTRICA}

A matriz elétrica no Brasil se torna mais renovável ainda, já que a maior parte da energia gerada vem das usinas hidrelétricas, compondo 64,9\% da matriz. Apesar de apresentarem números mais tímidos, a energia solar e eólica contribui com 9,6\% da matriz elétrica, porém tem crescido bastante na última década, contribuindo bastantes para que nossa matriz elétrica continue sendo, em sua maior parte, renovável, compensando a diminuição que a hidrelétrica teve.

Das fontes renováveis que compõem o quadro da matriz energética, de 2018 para 2019 ocorreu um decréscimo na geração de energia pelas fontes derivadas do petróleo, porém foi compensado pelo crescimento apresentado pela eólica e solar, conforme demonstra a Tabela 01 a seguir.

\begin{tabular}{|l|c|c|c|}
\multicolumn{4}{|c}{ Tabela 01 - Geração Elétrica (GWh) } \\
\hline Hidrelétrica & 2018 & 2019 & Variação 2019/2018 \\
\hline Gás Natural & 388.971 & 397.877 & $2,3 \%$ \\
\hline Biomassa & 54.622 & 60.448 & $10,7 \%$ \\
\hline Derivados de Petróleo & 52.267 & 52.543 & $0,5 \%$ \\
\hline Nuclear & 9.293 & 6.926 & $-25,5 \%$ \\
\hline Carvão Vapor & 15.674 & 16.129 & $2,9 \%$ \\
\hline Eólica & 14.204 & 15.327 & $7,9 \%$ \\
\hline Solar Fotovoltaica & 48.475 & 55.986 & $15,5 \%$ \\
\hline Outras & 3.461 & 6.655 & $92,2 \%$ \\
\hline Geração Total & 14.429 & 14.438 & $0,1 \%$ \\
\hline
\end{tabular}


Desta maneira, é importante salientar o investimento que tem sido feito no setor, pois são nítidos os resultados positivos que estão sendo alcançados na última década na geração de energia, sem falar no desenvolvimento local da região onde são feitos os investimentos através da geração de emprego e renda.

\subsubsection{ENERGIA EÓLICA}

A energia eólica é obtida a partir do aproveitamento dos ventos, que é o movimento das massas de ar, para a produção de energia elétrica, a qual depende de vários parâmetros que permitem predizer a viabilidade econômica e as características técnicas e operacionais do empreendimento. Desses parâmetros podemos citar a velocidade do vento, onde apresenta variação de velocidade, intensidade e direção; a rugosidade do terreno, pois, quanto maior a rugosidade, maior a diminuição da velocidade dos ventos; a altura, sendo que maiores velocidades são verificadas na medida em que se afasta do solo; e a direção do vento que varia ao longo de um determinado período.

Cada vez mais a energia eólica está sendo inserida no planejamento energético em todo o mundo. Isso é devido a algumas vantagens atreladas em seu favor: o vento é um combustível limpo e inesgotável, não emite gases poluentes; pode contribuir para a redução da emissão de gases de efeito estufa; permite geração de investimento em zonas desfavorecidas; e as turbinas eólicas possuem curto prazo de implantação, além de necessitar de pouca manutenção (semestral). Entretanto, apesar de se mostrar bastante competitiva, apresenta algumas desvantagens: nem sempre o vento sopra quando a eletricidade é necessária; altos custos de implantação; e impactos como, por exemplo, impacto visual, ruído audível, interferência eletromagnética, ofuscamento e danos à fauna, ainda que em pequenas escalas.

A utilização de fontes alternativas de energia é um grande desafio para a humanidade no sentido de atender à demanda mundial de energia. Essas fontes, apesar de serem menos agressivas ao meio ambiente, também terão de ser competitivas economicamente. A energia eólica é uma importante fonte renovável por ser limpa, abundante e que vem se tornando mais competitiva a cada dia. No Brasil, as regiões nordeste e sul são as áreas com maior potencial aproveitável, sendo que o Programa de Incentivo às fontes Alternativas de Energia Elétrica (PROINFA) teve papel fundamental para a viabilização do setor eólico no mercado de energia do país. 
A criação do PROINFA foi um marco para o desenvolvimento do setor de energia eólica no Brasil, instituído através da Lei $\mathrm{n}^{\circ} 10.438$ de 2002 e lançado em 2004. 0 objetivo do PROINFA é contratar projetos de energia eólica, biomassa e pequenas centrais hidrelétricas $(\mathrm{PCH})$ conectados à rede que fossem implementados por Produtores Independentes de Energia (PIE) ou Produtores Independentes Autônomos (PIA), conforme Decreto ${ }^{\circ} 5.025$ de 2004.

Entre os demais objetivos era diversificar a matriz energética brasileira, assegurando o abastecimento; valorizar as características e potencialidades regionais, com criação de empregos, capacitação e mão-de-obra; e reduzir a emissão de GEE. Os objetivos do PROINFA de incentivo ao uso de energia renovável estão em consonância com os objetivos do Mecanismo de Desenvolvimento Limpo (MDL) da convenção do clima de redução da emissão de GEE e promoção do desenvolvimento sustentável.

A abordagem do setor energético por meio da energia eólica se faz importante pelo fato de que a energia é essencial para o desenvolvimento da sociedade e faz parte do desenvolvimento econômico do país. Conforme o portal eletrônico Valor Econômico publicou em seu artigo intitulado "Brasil já tem produção de energia eólica equivalente a uma Itaipu", no dia 20/11/2018, a energia eólica ultrapassou a marca de 14,34 GW (gigawatts) de capacidade instalada no Brasil, patamar equivalente a uma usina de Itaipu - a segunda maior hidrelétrica do mundo. A fonte tem vivido um crescimento exponencial no país desde 2009, estimulada por leilões promovidos pelo governo federal para contratar novos empreendimentos. Isso fica evidenciado conforme gráfico abaixo que retrata o crescimento atingido nos últimos anos visto ser uma alternativa significativa para diversificação da matriz energética no país.

Recentemente, o município do Morro do Chapéu ingressou nas metas de sustentabilidade da ONU. Foi oficializada adesão aos Objetivos de Desenvolvimento Sustentável (ODS) da Organização das Nações Unidas (ONU) em evento realizado em 06/12/2018 na sede da cidade. As novas metas globais que irão vigorar até 2030, e incluem, por exemplo, a erradicação da pobreza, acesso ao saneamento básico e à energia renovável. 


\section{Gráfico 01 - Evolução da Energia Eólica (GWh)}

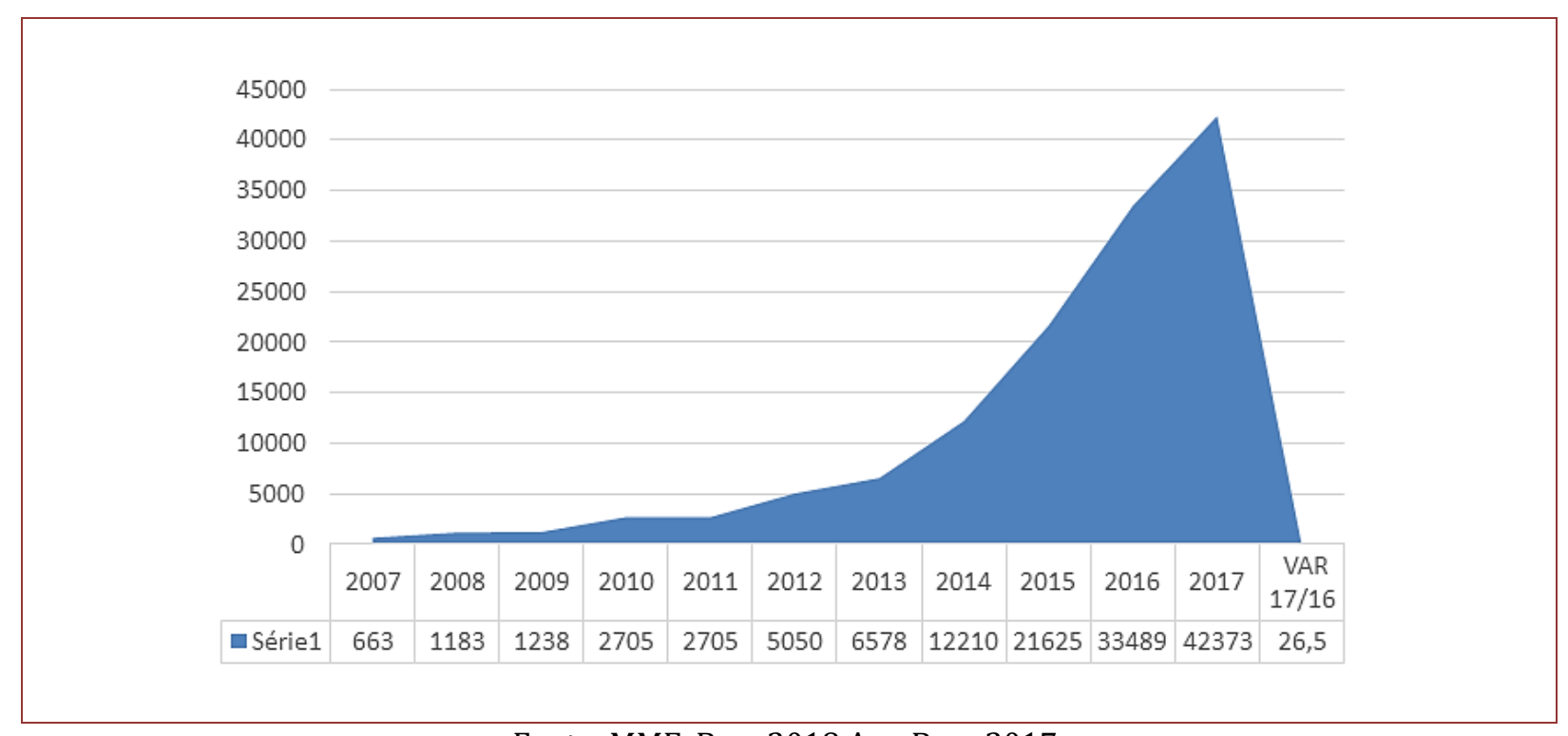

Fonte: MME. Bem 2018 Ano Base 2017.

Nos últimos anos, o município, segundo dados de 2017 do Instituto Brasileiro de Geografia e Estatística (IBGE), atraiu investimentos no setor de energia renovável, como o Parque Eólico Serra da Babilônia, administrado pelo Grupo Rio Energy.

\subsubsection{RIO ENERGY}

Rio Energy é um grupo comprometido com o futuro sustentável por meio do desenvolvimento, construção e operação de projetos de geração de energia renovável com os mais altos padrões de qualidade, criando valor social e econômico para as comunidades locais e parceiros.

Em Morro do Chapéu o grupo se faz presente por meio de sua subsidiária Copacabana Geração de Energia e Participações S.A. É uma sociedade por ações de capital fechado regida pelo Estatuto Social, Lei 6.404/76 e constituída no Brasil em setembro de 2015 e registrada na junta comercial do Rio de Janeiro. A companhia é totalmente controlada pela Rio Energy Fundo de Investimentos e Participações, fazendo parte do Grupo Rio Energy uma plataforma de investimentos fundada em 2012 com foco no desenvolvimento, construção e operação de ativos de geração de energia renovável no Brasil. 


\subsection{MORRO DO CHAPÉU}

\subsubsection{HISTÓRIA E LOCALIZAÇÃO}

Morro do Chapéu é uma cidade do semiárido baiano que, de acordo com a Superintendência de Estudos Econômicos e Sociais da Bahia (SEI), enquadra-se no Território de Identidade Chapada Diamantina e assim como Lençóis, Morro do Chapéu também se fez importante na época do ciclo do Diamante.

Os territórios de Identidade são conceituados no Decreto 12.354, de 25 de agosto de 2010 no seu $§ 1^{\circ}$. Considera-se Território de Identidade o agrupamento identitário municipal formado de acordo com critérios sociais, culturais, econômicos e geográficos, reconhecido pela sua população como o espaço historicamente construído ao qual pertence, com identidade que amplia as possibilidades de coesão social e territorial. 0 território de identidade Chapada Diamantina localiza-se majoritariamente no centro-sul baiano e corresponde a 5,6\% do território baiano.

Sua história, bem como o seu povoamento ocorreu em virtude da exploração de ouro na Freguesia de Jacobina em 1724, onde, na fazenda Gameleira, localidade que deu origem ao município, praticava a criação extensiva de gado que abastecia as minas de ouro. Por ordem econômica, foi necessária a abertura de estradas que ligavam Jacobina ao São Francisco e a Minas Gerais, passando pela fazenda Gameleira.

Em 1795, com a chegada do missionário capuchinho frei Clemente Adorno, edificou-se no local uma capela. Com isso deu origem a outras edificações, dando início ao povoamento. Em 1823 teve sua população aumentada, pois portugueses refugiados da perseguição dos nacionais resultante das lutas pela Independência do Brasil chegaram e se instalaram, estabelecendo fazendas de gado.

A capela que teve início de sua edificação em 1795 é concluída em 1834 e 4 anos depois o povoado é elevado a freguesia. 0 distrito foi criado pela Lei provincial n. ${ }^{\circ}$ 67, de 1. o de junho de 1838, sendo desmembrada de Santo Antônio da vila de Jacobina pela Lei Provincial de n.933, de 7 de maio de 1864, passando a se chamar Morro do Chapéu. Somente em 1909 a sede do município é elevada a cidade pela Lei estadual n.ํ 751 de 8 de agosto do referido ano.

A vila do Ventura, distrito de Morro do Chapéu criado pela Lei Estadual no 680 de 27 de agosto de 1906, foi de suma importância para cidade durante o ciclo do diamante, pois lá ocorria a extração do carbonato que era comercializado no mercado europeu, uma espécie de diamante que servia para produção de ferramentas cortantes e 
perfurantes. Assim como Lençóis, Morro do Chapéu se desenvolvia em função do diamante, que nos tempos de auge, a vila tinha um forte comercio instalado na praça comercial, duas escolas; uma estadual e outra municipal; e alguns professores particulares onde ensinavam a língua portuguesa e a francesa, agencia do correio, Associação dos Empregados do Comércio de Ventura, Teatro, Filarmônica 25 de dezembro, fundada em 1907, cemitério e uma grande capela.

Parte da estrada Real que Liga Jacobina a Rio de Contas passa pela vila que era principal via de escoamento local. A vila era responsável por mais de $50 \%$ da arrecadação do município. Tal era o desenvolvimento do distrito que, durante o ciclo, houve movimentação para ser emancipado. No entanto, com a decadência do carbonato, o sucesso da vila foi pelo mesmo caminho. A pavimentação da BA 052 que dista $8 \mathrm{~km}$ da Vila contribuiu para que ela se isolasse, perdendo de vez o caminho do progresso. A vila que um dia já foi bastante povoada, hoje é conhecida como cidade fantasma.

A cidade está localizada de forma a favorecer seu crescimento por ser cortada por algumas vias importantes para escoamento de sua produção e integração com as demais regiões no Estado, a qual pode citar a principal rodovia da região que é denominada BA 052. Ela é popularmente conhecida como estrada do feijão que liga Feira de Santana a Xique-Xique e sua importância é devido à conexão com a microrregião de Irecê, importante produtora de feijão e possui um comércio muito dinâmico e grande fluxo econômico.

Além da BA 052, a cidade também é seccionada pela BA 144, que recentemente foi revitalizada, trazendo melhorias para as condições dos produtores que precisam escoar sua produção para o norte do Estado, no Vale do São Francisco. Em seu trecho norte da rodovia faz ligação com a cidade de Jacobina, enquanto o trecho sul liga o município com a cidade de Bonito, grande produtor de café do Estado e contemplada com a implantação de parques eólicos. Após Bonito, ela passa por Utinga e Wagner, limitando-se ao encontrar com a BR 242. Por fim, tem-se a BA 422 que permite a ligação com as cidades de Miguel Calmon e Tapiramutá.

Devido a esse fator, por ser dotada de vias importantes, os imóveis da cidade têm uma valorização por permitir aos produtores maior facilidade em escoar suas produções com as diversas regiões do país. 


\subsubsection{DESCRIÇÃO GEOGRÁFICA E POTENCIAL GEOLÓGICO}

O município se destaca por apresentar um relevo montanhoso, onde sua altimetria varia de 800 a 1200 metros de altitude, e em algumas regiões podem ultrapassar essa cota. Uma área que se enquadra nessas características é o ponto turístico conhecido como Morrão e sua altimetria chega a 1293 metros. Este morro servia de referência para os antigos exploradores da região, dando origem à nomenclatura atual do município, onde relatavam que sua estrutura tinha forma de um chapéu. Atualmente este ponto serve também como apoio a estrutura de instalações de torres de telecomunicações que transmite os sinais para a cidade.

A comunidade recebe geólogos e estudantes de todo o Brasil a fim de proporcionar estrutura e recursos e por sua didática local, bem como sua relevância científica, além de sediar o Centro Nacional de Treinamentos do Serviço Geológico do Brasil - CPRM (CIEG). O Centro Integrado de Estudos Geológicos - CIEG foi inaugurado em abril de 1987 pelo Serviço Geológico do Brasil.

Destaca-se ainda o potencial geológico decorrente da exploração mineral que influencia a economia local. Consoante à Constituição Federal de 1988, em seu Art. 20, Parágrafo $1^{\circ}$ versa que:

é assegurada, nos termos da lei, aos Estados, ao Distrito Federal e aos Municípios, bem como a órgãos da administração direta da União, participação no resultado da exploração de petróleo ou gás natural, de recursos hídricos para fins de geração de energia elétrica e de outros recursos minerais no respectivo território, plataforma continental, mar territorial ou zona econômica exclusiva, ou compensação financeira por essa exploração. (BRASIL,1988).

A compensação financeira foi regulamentada pela Lei no 7.990, de 28 de dezembro de 1989 e que em seu Art. $6^{\circ}$ define, "para fins de aproveitamento econômico, será de até $3 \%$ (três por cento) sobre o valor do faturamento líquido resultante da venda do produto mineral, obtido após a última etapa do processo de beneficiamento adotado e antes de sua transformação industrial". Conforme dados da Compensação Financeira da exploração Mineral (CFEM) disponibilizados pela Agência Nacional de Mineração (ANM), cujos valores pesquisados foram registrados no período de 2007 a 2020, conforme Tabela 02: 
Tabela 02: Arrecadação CFEM 2007 a 2020 e variação no período.

\begin{tabular}{|c|c|c|}
\hline ANO & VALOR CFEM & VARIAÇÃO /ANO \\
\hline 2007 & - & \\
\hline 2008 & - & \\
\hline 2009 & $29.115,00$ & \\
\hline 2010 & $24.909,00$ & $-14,4462$ \\
\hline 2011 & $36.957,00$ & 48,36806 \\
\hline 2012 & $55.624,00$ & 50,51005 \\
\hline 2013 & $58.679,00$ & 5,492234 \\
\hline 2014 & $40.164,00$ & $-31,553$ \\
\hline 2015 & $35.794,00$ & $-10,8804$ \\
\hline 2016 & $163.182,00$ & 355,892 \\
\hline 2017 & $95.208,15$ & $-41,6552$ \\
\hline 2018 & $120.561,75$ & 26,62965 \\
\hline 2019 & $99.493,33$ & $-17,4752$ \\
\hline 2020 & $759.687,23$ & \\
\hline TOTAL & & \\
\hline & & \\
\hline & & \\
\hline
\end{tabular}

Fonte: ANM. CFEM 2020.

Os valores correspondem ao montante de $\mathrm{R} \$ 759.687,23$ (setecentos e cinquenta e nove milhões, seiscentos e oitenta e sete reais e vinte e três centavos), arrecadados no período de 2007 a 2020, sendo evidente o registro do início das atividades em 2009 e o aumento nos anos de 2017 a 2020, dado pela extração dos minerais: calcário, granito, quartzito e dolomito, destacados na Tabela 03 abaixo referenciada:

Tabela 03:Substâncias Minerais x Arrecadação CFEM 2017 a 2020

\begin{tabular}{|l|c|c|c|c|c|}
\multicolumn{1}{|c}{ MINERAL } & 2017 & 2018 & 2019 & 2020 & TOTAL \\
\hline Arenito & $3.063,48$ & - & - & - & $3.063,48$ \\
\hline Argila & 112,46 & 133,49 & 318,17 & 325,36 & 889,48 \\
\hline Calcário & $47.782,93$ & $30.085,63$ & $14.294,44$ & $20.583,71$ & $112.746,71$ \\
\hline Cascalho & $1.674,07$ & - & - & - & $1.674,07$ \\
\hline Dolomito & $4.755,35$ & $11.710,93$ & $5.507,86$ & $14.343,62$ & $36.317,76$ \\
\hline Granito & $44.775,10$ & $3.886,47$ & - & - & $48.661,57$ \\
\hline Mármore & $2.764,17$ & - & - & - & $2.764,17$ \\
\hline Quartzito & $58.254,87$ & $49.391,63$ & $100.441,28$ & $62.323,55$ & $270.411,33$ \\
\hline TOTAL & $163.182,43$ & $95.208,15$ & $120.561,75$ & $97.576,24$ & $476.528,57$ \\
\hline
\end{tabular}

Fonte: ANM. CFEM 2020.

A Compensação Financeira pela Exploração Mineral (CFEM) é arrecadada pelo Departamento Nacional de Produção Mineral - ANM, autarquia vinculada do 
Ministério de Minas e Energia, órgão que exerce a fiscalização sobre a arrecadação da CFEM. Calculada sobre o valor do faturamento líquido, quando o produto mineral for vendido. Entende-se por faturamento líquido o valor de vendo do produto mineral, deduzindo-se os tributos, as despesas com transporte e seguro que incidem no ato da comercialização.

\subsubsection{ATRATIVOS NATURAIS}

Morro do Chapéu possui três unidades de conservação (áreas legalmente protegidas): o Parque Estadual do Morro do Chapéu, Monumento Natural Cachoeira do Ferro Doido e APA Gruta dos Brejões/Veredas do Romão Gramacho. Além disso, a cidade dispõe de vários atrativos turísticos: Cachoeira do Ferro doido, Cachoeira do Agreste (I e II), Vila do Ventura (Toca da Figura, Cidade das Pedras, Poço da Barriguda e Cachoeira do Ventura), Cachoeira de Domingos Lopes, Morrão, Lagoa da Velha, Gruta dos Brejões, Gruta da Boa Esperança, Gruta Cristal, Buraco do Possidônio.

Em função de suas características fisiográficas, possui uma diversidade de ambientes, o que, devido as suas vantagens e limitações existentes, determinará sua atividade agropecuária a ser desenvolvida, com seus diferentes rendimentos e diferentes valores dos imóveis. Nas terras próximas à sede da cidade, apresentam baixa fertilidade, relevo ondulado, porém, chove inverno, possuindo disponibilidade hídrica subterrânea.

Nas regiões serranas que cortam o município há ocorrência de ventos muito fortes, além disso, por apresentar solos de baixa fertilidade, não são propícios ao desenvolvimento da exploração agrícola, sem disponibilidade hídrica e de baixa pluviosidade. Entretanto, apresenta um potencial para instalação de empreendimentos eólicos, podendo gerar royalties para os proprietários localizados nessa região.

Com esse intuito é que surgiu uma forte demanda por imóveis nessa região nos últimos anos, e onde houve a implantação dos empreendimentos eólicos, obteve-se valorização dos mesmos. No município de Morro do Chapéu foram adquiridos cerca de 8.196,25 ha pelo preço médio de $\mathrm{R} \$ 1.270,62 /$ ha (VTI/ha) totalizando $\mathrm{R} \$ 10.414 .307,84$. Desta maneira fica claro o potencial de aproveitamento dessas áreas inaptas para a atividade agrícola que os empreendimentos de geração de energia eólica podem proporcionar. 


\subsubsection{PERFIL SOCIOECONÔMICO DO MUNICÍPIO}

Morro do Chapéu, de acordo com o Instituto Brasileiro de Geografia e Estatística (IBGE), tinha, em 2019, uma população estimada em 35.413 pessoas. Conforme a SEI (2018), sua economia se distribui entre comércio e serviços, indústria e atividade agrícola, onde o setor de comércio e serviços predomina, representando 72,5\% do PIB. 0 setor de indústria representa 19,4\% e a agricultura representa 8,1\% do Valor Agregado Bruto (VAB). 0 estudo realizado pela SEI também nos traz números referentes ao estoque de emprego formal. Em 2017 apresentava um estoque de 3.199 postos, sendo que, os maiores estoques de empregos formais pertenciam: construção civil (964), comércio (335), serviços (380) e administração pública (1.311).

À vista disso, em 2018, o município, em relação ao Valor Adicionado, PIB e PIB per capita a preços correntes, se apresentavam da seguinte maneira:

Tabela 04 - Valor Adicionado

\begin{tabular}{|l|c|}
\hline Valor adicionado bruto a preços correntes série revisada & $347.996,15$ \\
\hline Atividade econômica & $26.470,43$ \\
\hline Agropecuária & $76.877,51$ \\
\hline Indústria & $125.243,36$ \\
\hline $\begin{array}{l}\text { Serviços - exclusive administração, defesa, educação e saúde públicas e } \\
\text { seguridade social }\end{array}$ & $119.404,85$ \\
\hline Administração, defesa, educação e saúde públicas e seguridade social & \\
\hline
\end{tabular}
Fonte: SEI (2018); IBGE (2020).

Observa-se que no município o setor que mais gera empregos e rendas são voltados a indústria e serviços - exclusive a administração, defesa, educação e saúde públicas e seguridade social, notando uma participação significativa da administração, defesa, educação e saúde públicas e seguridade social e da agropecuária. Por se tratar de um município pequeno, é marcante que a administração pública seja um grande polo de oferta de emprego, contribuindo desta maneira por parte considerável da renda da população.

Em relação ao número de estabelecimentos por setores de atividade econômica:

Tabela 05 - Valor Adicionado

\begin{tabular}{|l|c|}
\multicolumn{1}{|c|}{ Setor de atividade } & Quantidade \\
\hline Extrativa mineral & 8 \\
\hline Indústria de transformação & 12 \\
\hline Serviços industriais de utilidade pública & 2 \\
\hline Construção civil & 14 \\
\hline Comércio & 113 \\
\hline Serviços & 66 \\
\hline Administração pública & 2 \\
\hline Agropecuária, extração vegetal, caça e pesca & 23 \\
\hline Total & 241 \\
\hline
\end{tabular}


$\mathrm{Na}$ administração pública, apenas 2 estabelecimentos são responsáveis por encabeçar a geração da maior parte dos polos de empregos. Nesse quesito, o comércio detém maior parte dos estabelecimentos, contribuindo de maneira significante na renda dos munícipes. Em virtude da construção dos parque eólicos, surgiram novos estabelecimentos na construção civil e serviços industriais, aquecendo a economia da região.

\section{METODOLOGIA}

O campo empírico compreendeu o Município de Morro do Chapéu/BA, onde foram coletados dados que permitiram realizar um comparativo de resultados durante diferentes exercícios financeiros e acompanhar a evolução da arrecadação municipal influenciados possivelmente pela exploração dos recursos naturais e implantação de parques eólicos na localidade, além da utilização do Relatório de Impactos Ambientais disponibilizados pela Biodinâmica Engenharia e Meio Ambiente sobre o Complexo Eólico Serra da Babilônia.

A pesquisa usufruiu de ferramentas eletrônicas para a elaboração de planilhas e tornar mais didática a elucidação do problema, facilitando a compreensão da temática e auxiliando na sua análise de dados. Desta maneira, foram consultados portais como o portal do Tribunal de Contas dos Municípios do Estado da Bahia (TCM), Superintendência de Estudos Econômicos e Sociais da Bahia (SEI) e Sistema de Informações Contábeis e Fiscais do Setor Público (SICONFI).

\section{ANÁLISE DOS DADOS DA IMPLANTAÇÃO DA ENERGIA EÓLICA}

\subsection{ANÁLISE DE IMPACTOS DA ENERGIA EÓLICA EM MORRO DO CHAPÉU}

O Estudo dos Impactos Ambientais (EIA) é uma exigência prevista nas regulações federal e estadual para as atividades que modifiquem o meio físico, conforme a legislação do CONAMA 001/86 e que provoquem riscos ao meio ambiente. A legislação vigente integra os seguintes documentos: 
1. DECRETO № 14.024/2012 - Aprova o Regulamento da Lei no 10.431, de 20 de dezembro de 2006, aplicado as atividades agrossilvopastoris, da indústria, de serviços, urbana, mineração, relacionadas ao uso de recursos hídricos, inclusive as de infraestrutura de transporte e energia (eólica).

2. RESOLUÇÃO CONSELHO ESTADUAL DO MEIO AMBIENTE - CEPRAM № 4.180 DE 29 DE ABRIL DE 2011 - Dispõe sobre a Regularização ambiental de empreendimentos de geração de energia elétrica a partir de fonte eólica, conforme as Normas gerais estabelecidas na Política Estadual de Meio Ambiente. Portaria no 11.292/2016 - Define os procedimentos e a documentação necessária para formação processo para regularidade ambiental de empreendimentos e;

3. Requerimento no Sistema Estadual de Informações Ambientais e Recursos Hídricos - SEIA, enquadramento e classificação do empreendimento (porte X potencial de impacto, eólico pequeno potencial), reclassificação para Classe 6, conforme CEPRAM e CONAMA 462/2014).

Nesse contexto, a Resolução CONAMA no 01, de 1986, Art. 1ํㅡㄹ define que o impacto ambiental representa qualquer alteração das propriedades físicas, químicas e biológicas do meio ambiente, causada por diversas formas de matérias ou energia, resultante das atividades humanas que, direta ou indiretamente, afetem a saúde, a segurança e o bem estar da população, as atividades sociais e econômicas, as condições estéticas e sanitárias do meio ambiente e a qualidade dos recursos ambientais (BRASIL, 1986).

O RIMA (2018, p. 203), os principais impactos ambientais decorrentes da atividade eólica consideram a delimitação das Áreas de Influência do empreendimento feita a partir da análise preliminar de aspectos sobre os meios físico, biótico e socioeconômico, nas etapas de planejamento, implantação e operação apresentadas no Quadro 1: 
Quadro 1 - Lista de aspectos ambientais da atividade de eólica.

\section{MEIO FÍSICO}

- As temperaturas encontradas nas Áreas de Influência do empreendimento ficam, em médias anuais, entre a mínima de $15,9^{\circ} \mathrm{C}$ e a máxima de $25,1^{\circ} \mathrm{C}$, mantendo $19,5^{\circ} \mathrm{C}$ como temperatura média no ano.

- A Umidade Relativa do Ar Média Anual, na região do empreendimento, varia entre 73,4 e 85,1\%, com relação direta com a variação da Temperatura Média (INMET)

- Os ventos na região de Morro do Chapéu são constantes e com velocidade média anual se mantendo entre 3 e 4,5m/s. A direção predominante varia entre leste e sudeste.

- As chuvas durante o ano ocorrem concentradas nos meses de novembro até abril, com o pico chuvoso no mês dezembro. No total anual, em média, a região possui áreas com altura de chuvas entre $95 \mathrm{~mm}$ até $127,4 \mathrm{~mm}$.

- $\quad 0$ empreendimento está localizado em uma área de grande incidência de raios solares. Em junho, são registrados os menores valores de concentração da radiação solar (brilho do sol) e os valores máximos são registrados nos meses de agosto e novembro.

\section{MEIO BIÓTICO}

- As plantas na Caatinga normalmente são baixas e com muitos espinhos, com troncos finos e folhas pequenas. Representadas por cactos, suculentas em 4.508 espécies diferentes da flora, e 318 delas são exclusivas da Caatinga.

- Em relação a fauna, na região do empreendimento foram encontradas 424 espécies. Na região do empreendimento, foram encontradas 3 espécies ameaçadas de extinção e 20 espécies que possuem o comércio restrito.

- A vegetação é uma Caatinga bem fechada, dominada por arbustos, com algumas árvores isoladas. A altura varia entre 2 e $5 \mathrm{~m}$, com alguns lugares chegando a $8 \mathrm{~m}$. No total, foram encontradas 82 espécies diferentes, entre arbustos, árvores e plantas rasteiras. As espécies encontradas em maior número foram o angico-liso, o pereiro e a unha-de-gato. Para o local do empreendimento, foram encontradas duas espécies ameaçadas de extinção (coroa-de-frade e setecascas) e 11 espécies com comércio restrito, a maioria delas cactos.

Fonte: RIMA, Complexo Eólico-Solar Serra Da Babilônia (2018, p.14). Elaborado pelo autor.

Em análise do Relatório de Impacto Ambiental Complexo Eólico-Solar Serra da Babilônia (2018, p.14) destaca os aspectos naturais, considerando o meio físico, biótico e em relação ao meio antrópico/socioeconômico da Área Diretamente Afetada (ADA), da Área de Influência Direta (AID) e Área de Influência Indireta (AII).

Os estudos socioeconômicos da população dos municípios baianos de Ourolândia, Várzea Nova, Morro do Chapéu e Jacobina, abrangidos pelo empreendimento, basearamse em levantamentos de dados estatísticos municipais e estaduais, disponíveis em fontes oficiais e em trabalhos de campo realizados em outubro de 2016.

\subsection{ANÁLISE DA ARRECADAÇÃo DO MUNICÍPIO E PROVÁVEL AUMENTO DA RECEITA OU INFLUÊNCIA DA ATIVIDADE EÓLICA}

Como se verifica na maioria dos municípios brasileiros, de acordo com os dados divulgados pela SEI, Morro do Chapéu apresentava uma receita própria em 2014 de $6,1 \%$ em relação à receita corrente. Caracteriza-se uma vulnerabilidade fiscal com baixa 
capacidade de receitas próprias, tornando mais vinculada aos programas sociais do governo federal, principalmente para custeio em educação, saúde, saneamento básico e investimentos em infraestrutura. Desta forma, dificulta a execução de políticas públicas para a melhoria da qualidade de vida da população.

Levando-se em consideração os impactos sociais e ambientais causados pela exploração da atividade eólica, vale ressaltar a expectativa do aumento da arrecadação dos tributos inerentes à atividade. Para fins de melhor alcance dos objetivos propostos quanto à contribuição da arrecadação tributária com base na implantação dos parques eólicos, não foi possível mensurar com clareza o quanto contribuiu efetivamente. Contudo, com o auxílio do portal do Sistema de Informações Contábeis e Fiscais do Setor Público Brasileiro - SICONFI foi possível fazer uma coleta de dados de valores arrecadados por meio das Demonstrações Contábeis da Prefeitura Municipal de Morro do Chapéu nele publicadas, permitindo elaborar um quadro comparativo para acompanhar a evolução na arrecadação de tributos, mais especificamente do ISS e ICMS, e inferir de forma estimada a contribuição.

Tabela 06 - Arrecadação de tributos

\begin{tabular}{|c|c|c|c|c|}
\multirow{2}{*}{$\begin{array}{c}\text { Exercício } \\
\end{array}$} & Arrecadação ISS (R\$) & \multicolumn{2}{c|}{$\begin{array}{c}\text { Part. Receitas do Estado } \\
\text { ICMS (R\$) }\end{array}$} & \multicolumn{1}{c|}{$\Delta \%$} \\
\hline 2013 & $1.523 .174,64$ & $100 \%$ & $6.374 .502,56$ & $100 \%$ \\
\hline 2014 & $2.257 .994,69$ & $148 \%$ & $6.489 .486,31$ & $101,80 \%$ \\
\hline 2015 & $2.334 .543,23$ & $103,39 \%$ & $6.926 .414,55$ & $106,73 \%$ \\
\hline 2016 & $1.494 .387,12$ & $64,01 \%$ & $6.971 .178,83$ & $100,65 \%$ \\
\hline 2017 & $6.561 .485,71$ & $439,08 \%$ & $11.194 .076,97$ & $160,58 \%$ \\
\hline 2018 & $11.822 .316,14$ & $180,18 \%$ & $11.540 .429,28$ & $103,09 \%$ \\
\hline 2019 & $6.763 .653,41$ & $57,21 \%$ & $9.551 .795,98$ & $82,77 \%$ \\
\hline
\end{tabular}

Fonte: Sistema de Informações Contábeis e Fiscais do Setor Público Brasileiro - SICONFI, elaborado pelo autor.

Diante deste cenário do desenvolvimento da atividade eólica no município, se torna uma oportunidade de amenizar a dependência fiscal de transferências e repasses do Estado e União, pois há uma expectativa de maior arrecadação por meio dos tributos. No momento em que há o aumento das receitas via tributos, o poder executivo irá dispor de mais recursos para aplicar em benefício da comunidade, buscando sempre o bemestar da coletividade.

Verificando o comportamento da arrecadação de tributos durante os exercícios financeiros apresentados na tabela, nota-se uma crescente arrecadação entre os períodos de 2013 a 2018, exceto no ano de 2016 que apresentou uma redução.No 
entanto, ocorreu uma enorme arrecadação de ISS e participação nas receitas através do repasse de ICMS entre 2017 e 2018. Pode-se estimar que essa crescente arrecadação que obteve nos períodos de 2017 e 2018 tenha uma grande parcela de participação da exploração da atividade eólica, período esse que o município passou por uma intensa movimentação na economia local por meio da chegada de empresas terceirizadas para prestação de serviços na construção dos complexos eólicos.

\section{CONSIDERAÇÕES FINAIS}

A pesquisa buscou caracterizar os possíveis efeitos que os parques eólicos poderiam gerar nas dimensões econômica, social e ambiental ao longo da implantação dos mesmos na cidade de Morro do Chapéu, que para tal objetivo foi necessário discorrer e fundamentar-se na Contabilidade Socioambiental; bem como elucidar o conceito de energia limpa, dedicando-se na energia de fonte renovável a partir dos ventos; e apresentou os impactos econômico, social e ambiental da atividade eólica no município com o intuito de evidenciar sua contribuição na arrecadação municipal por intermédio da tributação do ISS e ICMS.

Para analisar os impactos referidos em trecho anterior, foi fundamental contextualizar os aspectos socioeconômicos e mostrar os potenciais econômicos que o município dispõe, destacando a composição do seu território, elencando pontos referentes à formação geológica, atividades econômicas desenvolvidas e a composição de sua economia.

A investigação pretendia ser realizada abrangendo todos os complexos existentes na localidade, contudo, só foi possível encontrar relatórios específicos do Complexo Serra da Babilônia. Na oportunidade pretendeu-se abranger o Complexo Eólico Morro do Chapéu Sul administrado pelo Grupo Enel Green Power, no entanto o autor teve dificuldades de localizar ou verificar a existência de Estudos de Impactos Ambientais do mesmo. Com o auxílio do Estudo dos Impactos Ambientais foi possível identificar nas atividades as modificações que o meio físico sofreu, no qual o RIMA pode esclarecer os principais impactos ambientais decorrentes da atividade eólica, onde considerou a delimitação das Áreas de Influência do empreendimento feita a partir da análise preliminar de aspectos sobre os meios físico, biótico e socioeconômico, nas etapas de planejamento, implantação. 
Percebeu-se que desde a época da fundação do município, ele gera riqueza a partir da exploração de recursos naturais, o qual, na ocasião, utilizava-se da exploração do diamante, porém a atividade não provinha de recursos renováveis. No decorrer do referencial teórico o autor se deparou com informações que não tinha conhecimento da existência e que considerou de suma importância para geração de riqueza do município, onde constatou em meio aos aspectos e potencial geológico a compensação financeira da exploração mineral.

Por fim, uma das indagações que motivaram a realização dessa investigação científica, no que tange a arrecadação de tributos oriundos da exploração da atividade eólica no município. Verificou-se que nos últimos anos ocorreu um aumento significativo na percepção de tributos, sendo essas informações coletadas a partir das Demonstrações Financeiras da prefeitura de Morro do Chapéu, mas que não foi possível precisar o quanto foi proveniente da implantação e operação dos parques eólicos.

Recomenda-se que futuramente o estudo avance no sentido de avaliar os impactos proporcionados na economia local envolvendo geração de emprego e renda, bem como o surgimento de nichos mercadológicos provenientes da influência desses parques instalados, além de verificar se ocorreram melhorias no quesito transparência das arrecadações supracitadas, não deixando de acompanhar os impactos ambientais pós-implantação e início da operação dos parques.

\section{REFERÊNCIAS}

[1] ASSOCIAÇÃO BRASILEIRA DE NORMAS TÉCNICAS. NBR 14724: informação e documentação - Trabalhos Acadêmicos - Apresentação. Rio de Janeiro: ABNT, 2011.

[2] BRAGA, Célia. Contabilidade Ambiental: ferramenta para a gestão da sustentabilidade. São Paulo: Atlas, 2007.

[3] BRASIL. Constituição Federal (1988). Constituição da República Federativa do Brasil, promulgada em 5 de outubro de 1988. Presidência da República. Casa Civil. Subchefia para Assuntos Jurídicos. Disponível em: <http://www.planalto.gov.br/ccivil_03/constituicao/constituicao.htm>. Acesso em: 29 jun. 2019.

[4] .Disponível em: <http://www.planalto.gov.br/ccivil_03/LEIS/L7990.htm>. Acesso em: 20 Ago. 2019.

[5] Empresa de Pesquisa Energética. Balanço Energético Nacional 2020: relatório síntese ano base 2019. Disponível em: <https://www.epe.gov.br/sites-pt/publicacoesdados-abertos/publicacoes/PublicacoesArquivos/publicacao-479/topico521/Relato\%CC\%81rio\%20Si\%CC\%81ntese\%20BEN\%202020-ab\%202019_Final.pdf >. Acesso em: 05 Maio. 2021. 
[6] FERRARI, Ed Luiz. Contabilidade Geral. 12ª ed. Niterói: Impetus, 2012.

[7] IBGE - Cidades. Morro do Chapéu: histórico. Disponível em: <http://www.cidades.ibge.gov.br/painel/historico.php?lang=\&codmun=292170\&searc $\mathrm{h}=\% 7$ Cmorro-do-chapeu>. Acesso em: 30 jun. 2019.

[8] INCRA - Instituto Nacional de Colonização e Reforma Agrária. Relatório de análise de mercados de terras de Morro do Chapéu. Disponível em: < http://www.incra.gov.br/sites/default/files/uploads/reforma-agraria/relat-rios-de-anlise-de-mercados-de-terra-ramts-/sr-05---

bahia/01_ramt_sr05_ba_mrt_morro_do_chapeu.pdf>. Acesso em: 30 jun. 2019.

[9] INEMA - Instituto do Meio Ambiente e Recursos Hídricos. EIA RIMA. Disponível em: <http://www.inema.ba.gov.br/estudos-ambientais/avaliacao-ambiental/eiarima/>. Acesso em: 05 Ago. 2019.

[10] Lei no 10.431 de 20 de dezembro de 2006 Disponível em: < http://www.seia.ba.gov.br/sites/default/files/legislation/Lei\%2010431_2006.pdf>. Acesso em: 20 Ago. 2019.

[11] PRESIDÊNCIA DA REPÚBLICA CASA CIVIL. Disponível em: <http://www.planalto.gov.br/ccivil_03/LEIS/2002/L10438.htm>. Acesso em: 04 Ago. 2019.

[12] Resolução no 4.180 de 29 de abril de 2011. Disponível em: < http://www.seia.ba.gov.br/legislacao-ambiental/resolucoes/resolu-o-cepram-n-4180>. Acesso em: 20 Ago. 2019.

[13] SANTOS, Marco Aurélio dos. Fontes de Energia Nova e Renovável. Rio de Janeiro: TLC, 2013.

[14] SEI - Superintendência de Estudos Econômicos e Sociais da Bahia. Perfil dos

Territórios de Identidade da Bahia. Disponível em:
http://www.sei.ba.gov.br/index.php?option=com_content\&view=article\&id=2000\&Item id=284. Acesso em: 05 Maio. 2021.

[15] SICONFI -Sistema de Informações Contábeis e Fiscais do Setor Público Brasileiro.

Disponível em:

<https://siconfi.tesouro.gov.br/siconfi/pages/public/declaracao/declaracao_list.jsf>.

Acesso em: 05 Maio. 2021. 


\section{Capítulo 7}

Literatura infantil: Uma análise acerca da mediação tecnológica como suporte na contações de histórias

Aline Silva Santos

Ediane Oliveira dos Santos

Daniela Lopes Oliveira Dourado 
RESUMO: A evolução tecnológica e as novas formas de produzir, apresentar, divulgar e acessar conhecimento, dialogando com as práticas pedagógicas, modificaram também as formas como o indivíduo ouve as histórias. Ainda há um narrador e um ouvinte, mas, não precisam necessariamente estar no mesmo ambiente, com as diversas mudanças ocorridas no mundo, as narrativas da literatura infantil, foram adaptadas para o uso dos recursos tecnológicos, principalmente em plataformas de vídeo como o Youtube, que também permitem a interação entre narrador e ouvinte. Assim, fez-se necessário compreender as narrativas da literatura infantil exploradas com o uso da mediação tecnológica na Educação Infantil. Tratou-se de uma pesquisa de cunho qualitativo, com estudo documental, utilizando como instrumento a análise de conteúdo, apresentando levantamento dos contextos históricos e atuais, com ênfase no tema central da pesquisa, utilizando a análise do conteúdo para investigação por meio de tabela comparativa para a coleta e análise dos dados. Sendo perceptível que a qualidade da contação de histórias depende do planejamento, da escolha da história, das técnicas que serão utilizadas, enfatizando que nos canais escolhidos, o discurso da linguagem para as crianças é realizado e elaborado de forma significativa. Nessa pesquisa torna visível perceber que a contação de histórias com a mediação tecnológica apresenta os mesmos objetivos de contação de histórias tradicionais, divergindo apenas nos métodos e aspectos.

PALAVRAS-CHAVE: Contação de História. Literatura Infantil. Mediação Tecnológica. 


\section{INTRODUÇÃO}

Considerando a realidade que o mundo se encontra, de distanciamento social devido à pandemia do covid-19 e no Brasil especificamente desde março de 2020, as escolas precisaram modificar drasticamente os processos de ensino, além disso, os espaços pedagógicos como bibliotecas que possuem diversos gêneros e tipos de leituras, tão importantes para fomentar ainda mais o gosto da criança pela leitura, permanecem fechadas, por cumprimento de segurança, dessa forma, foram adotadas estratégias com o ensino remoto, previstas pelo Conselho Nacional de Educação (CNE).

Diante desta realidade, as práticas pedagógicas precisaram ser adaptadas por meio de ferramentas tecnológicas, exigindo uma nova relação com os estudantes e criatividade dos educadores, qual inevitavelmente, o momento do trabalho pedagógico com a Literatura Infantil também precisou de adaptação através dos meios tecnológicos de informação, como plataformas específicas, que para determinados autores são chamados momentos de contações de histórias contemporâneas.

Momentos como esse, já eram oferecidos através de algumas plataformas digitais de compartilhamento de vídeos, tais como Youtube, dado que momentos de educação não formal no âmbito da educação não escolar, porém em decorrência a pandemia, tornou-se usual de muitas instituições no contexto da educação formal.

Em contrapartida, sabe-se dos problemas sociais que afligem o país, a desigualdade social e econômica revelou sérios problemas para o acesso ao conhecimento através do uso das ferramentas tecnológicas e o acesso à internet. Isso tem promovido exclusão e dificultado o acompanhamento dos processos de ensino de milhares de estudantes pelo país, principalmente da escola pública.

Diante desse contexto surgiu o questionamento, sobre como mantinham-se, o acesso à leitura e contação de história diante desse novo contexto, a partir do exposto, é de suma importância compreender como as narrativas da Literatura infantil são exploradas na mediação tecnológica, como recurso para a educação infantil no distanciamento social, devido a pandemia do Coronavírus para dialogar com o imaginário das crianças.

Assim, levando em consideração todos esses aspectos, para se obter um bom resultado a pesquisa se divide em levantar os contextos históricos da mediação das narrativas infantis, identificar as plataformas digitais exploradas para a contação de histórias, analisar o diálogo mediador com crianças, nos canais digitais de trabalho 
pedagógico com a Literatura Infantil e analisar a colaboração dos canais de contação de histórias para a educação infantil durante a pandemia do coronavírus.

Para isso, foi utilizada como método de pesquisa, pesquisa qualitativa de caráter descritiva, exploratória e a análise de conteúdo para a análise dos dados, sendo possível realizar uma investigação do perfil e dos conteúdos, dos canais digitais investigados que apresentam a proposta de anunciar a Literatura infantil através de meios tecnológicos.

Logo, nessa pesquisa tornou-se visível uma das muitas características fundantes do pedagogo, de se reinventar a cada momento, buscando sempre o aperfeiçoamento didático, mesmo que em tempos de pandemia. Além disso, exterioriza o valor da tecnologia e de suas mais variáveis funções, sendo atribuído ao conceito de peça fundamental nesse processo. Portanto, vem apresentando com relevância social a interação da educação a partir da necessidade, diante do isolamento social, trazendo possibilidades para professores, educandos, pais, estudantes e profissionais da área da educação o contato com a leitura, a partir do ato de contar e ouvir histórias, de uma forma diferenciada, mediada pela tecnologia.

\section{CONTEXTO HISTÓRICO DAS NARRATIVAS INFANTIS}

Narrativa segundo o dicionário Aurélio, significa ação, efeito ou processo de narrar, de relatar, de expor um fato, um acontecimento, uma situação (real ou imaginária), por meio de palavras; narração expressa em texto popular como conto, causo, entre outros. As narrativas são ferramentas de ensino utilizada no mundo inteiro por educadores e educadoras a fim de auxiliar no suporte do processo de ensino aprendizagem, sendo exploradas de diferentes maneiras.

Para falar das histórias infantis é necessário conhecer a trajetória das narrativas como um todo. Segundo Busatto (2012) por muito tempo as narrativas eram contos, histórias, lendas de povos que se reuniam ao redor de fogueiras em tribos, transmitidos de geração para geração. Nessa perspectiva, na cultura oriental, os contos orais eram muito mais que apenas um gênero literário, os conhecimentos contidos nas narrativas eram formas de condutas, resgates de valores, até mesmo apresentação de procedimentos medicinais, como também crenças religiosas e conhecimentos artísticos.

Nesse sentido, mesmo não sabendo ao certo o momento do surgimento das narrativas orais, muitos estudiosos partem do princípio, que surgiram a partir da 
necessidade intrínseca do homem de explicar fenômenos como, por exemplo, a sua própria existência.

Assim, para Busatto (2012) fosse os contos um sistema de crenças ou uma maneira encontrada para explicar a existência dos elementos da natureza, isto contribuiu para o que hoje é conhecido como Literatura oral e que foi se transformando à medida que foi sendo narrada, já que com o passar dos séculos as narrativas sofrem alterações na medida em que são transmitidas, considerando também que os primeiros registros são datados de 200.000a.C aproximadamente 400.000a.c.

Diante desses fatos não se pode esquecer que desde a ancestralidade, cada povo, cada cultura, cada narrador de histórias sempre inclui elementos próprios, transformando a literatura oral em matéria viva e adaptada. Os contos e narrativas sempre estiveram presentes durante o contexto de vida em sociedade, porém, a concepção de textos e narrativas para crianças surgiram em um tempo histórico recente.

Logo, como se sabe o homem usa as narrativas para desenvolver, indicar, construir e se manter na história, assim o uso da linguagem oral como já citado vai além de passar conhecimentos de gerações, é também uma forma de representatividade e analogias de soluções de problemas que já foram resolvidos, como também uma forma de manter uma língua viva e em constante construção, e é por meio disto que se realiza a manutenção das tradições de um povo, para assim serem lembrados.

As narrativas infantis surgiram também com o intuito de passar formas de condutas, considerando que o conceito de infância se perpetuou muito com o passar dos séculos, como a exemplo na idade média, época na qual as crianças eram vistas e postas na sociedade como miniaturas de adultos, a leitura e a ação de ouvir histórias era permitida e limitada apenas para filhos de nobres e burgueses, crianças camponesas eram restritas apenas a lendas e contos populares, geralmente, seguindo os passos de seus pais e antepassados.

Conforme Cademartori (1986, p. 38-39), “a criança, na época, era concebida como um adulto em potencial, cujo acesso ao estágio dos mais velhos só se realizaria através de um longo período de maturação". Mediante as diferentes imagens do conceito de infância que a história tem tornado oportuno, permite-se, então, caracterizar as vidas de crianças em diferentes espaços e períodos históricos, também a forma como adultos e crianças continuamente constroem e reconstroem as suas percepções acerca da infância, tal qual, 
A partir do momento que a infância é reconhecida e a criança começa a ser vista com suas peculiaridades e características, a Literatura e as narrativas começaram a passar pelo processo de adaptação, por meados do século XVII, o escritor francês Charlles Perrault ${ }^{3}$ ficou conhecido como pai da Literatura infantil, pois estabeleceu as fases de um novo gênero literário, tendo uma linguagem própria de escrever, um público recortado, se distinguindo das demais.

De acordo com Cademartori (1986), a época em que Perrault coletou seus contos foi penosa e de grandes transformações e contradições sociais, momento após a Fronde, movimento popular de oposição ao governo absolutista do reinado de Luís XIV, nesse mesmo contexto a época também foi marcada pelo conflito entre Reforma e Contra Reforma, também pela ascensão da burguesia como classe social, fato determinante para a consolidação de instituições como a família e a escola.

Segundo Coelho (1998), no princípio, o trabalho de adaptação dos contos orais, por Perrault, não foi pensado com intenções de criar uma Literatura destinada à criança, e sim a nobres e pessoas da alta corte, apenas a partir do entendimento das concepções de infância, levando em consideração suas características e significância, as histórias foram adaptadas para o público infantil sendo, Contos da mamãe Gansa, livro pioneiro publicado em 1967, por Perrault.

\title{
2.1 NARRATIVAS E LITERATURA ORAL NO BRASIL
}

Se tratando das narrativas e Literatura oral do Brasil, não diferentemente das demais, reúnem-se e concentram nos contos folclóricos, mantidos por manifestações populares, advindas das multiculturalidades envolvidas no Brasil, como indígena, africana, portuguesa e outros povos.

\begin{abstract}
A Literatura Oral brasileira se comporá dos elementos trazidos pelas três raças para a memória e uso do povo atual, indígenas, portugueses e africanos possuíam cantos, danças, estórias, lembranças guerreiras, mitos, cantigas de embalar, anedotas, poetas e cantores profissionais, uma já longa e espalhada admiração ao redor dos homens que sabiam falar e entoar (CASCUDO, 1984, p.29).
\end{abstract}

Assim, para abordar as narrativas orais do Brasil, é importante partir do pressuposto de que antes da chegada dos colonizadores e invasores, aqui já viviam povos indígenas, que perpetuavam sua cultural oral, principalmente para o que se

\footnotetext{
${ }^{3}$ Escritor e arquiteto francês célebre pela coletânea para crianças Contos da Mãe Gansa que publicou em 1697, com o nome de seu filho Perrault d'Armancour.
} 
tratava de narrativas as quais explicavam desde lendas para proteção da floresta, até apresentação de crenças e divindades religiosas.

No século XVI, início do chamado tráfico negreiro, quando prisioneiros africanos eram escravizados e trazidos para o Brasil, ali também eram trazidas suas narrativas, crenças, lendas e cultura, assim como afirma Cascudo (1998) as estórias mais populares do Brasil, não são mais regionais, ou julgadamente nascidas no país, mas aquelas de caráter universal, antigas, seculares, espalhadas.

Acredita-se que a contação de história tem seu começo mesmo antes de surgir o próprio sistema de escrita, pois foi algo advindo desde a pré-história até chegar aos dias atuais, antes, essa prática de contar histórias nas escolas era utilizada como uma forma de passar o tempo, de prender a atenção das crianças para tentar evitar uma possível bagunça.

Assim sendo, no contexto escolar atual, a contação de histórias torna- se um ato imprescindível nas creches e pré-escolas, momento o qual para muitas crianças esse é seu primeiro acesso ao mundo literário, muitos tem esse como o único momento literário do dia, sendo por inúmeros motivos como: falta de recursos, de incentivo, desigualdade social, ausência da família, assim como diversos fatores.

Para isso, os ambientes escolares precisam oferecer os momentos de formações continuadas para que os professores estejam atualizados sobre técnicas de contações de histórias, para então, proporcionar um momento de leitura significativo na vida das crianças. Como também, um ambiente no qual proporciona o livre acesso aos livros, para tornar familiar o ato de ler, dessa forma, que o torna muitas vezes muito difícil.

\subsection{LEITURA E EDUCAÇÃO INFANTIL}

O Conselho Nacional de Educação (CNE) vem, por meio das Diretrizes Curriculares Nacionais (DCN's) suscitar que:

$\operatorname{Art}^{\circ}$ 29. Do ponto de vista legal, a Educação Infantil é a primeira etapa da educação básica e tem como finalidade o desenvolvimento integral da criança de zero a cinco anos de idade em seus aspectos físicos, afetivo, intelectual, linguístico e social completando a ação da família e da comunidade (BRASIL,1998)

A primeira infância é caracterizada como uma fase de descobertas, de novas experiências que proporcionam afinar conhecimentos que se dão por intermédio de interações com o meio em que estão inseridos, possibilitando a construção social, moral e intelectual da criança, e muitas dessas experiências no âmbito escolar, a primeira 
infância apresenta uma maior facilidade em habitar em um reino ilusório de imaginação e fantasia.

Experiências com leituras são imprescindíveis na vida de uma criança, é notável que a mesma, está presente no cotidiano, desde as situações mais habituais, como por exemplo, preparar uma receita de bolo de chocolate ou mesmo lendo uma bula de remédio, às mais complexas, a exemplo das pesquisas científicas, sentenças matemáticas e etc.

As possibilidades de leitura são amplas e podem ser contempladas de diversas maneiras, até mesmo em uma simples contação de história, sendo assim, pode-se pensar em leitura nas suas mais variadas vertentes, como prática por lazer, conhecimento e necessidade diante de alguma situação.

Porém, para tais práticas do ato de leitura é necessário que haja uma mediação, seja ela de provocação, indagação ou incentivo. Tal mediação ocorre por meio de professores e que mais da metade da população brasileira não tem acesso há livros ou bibliotecas tornando o ato de leitura dificultoso.

Tendo em vista a pesquisa do Instituto Pró-Livro e estudos sobre a Educação infantil percebe-se, que a primeira infância traz em si a noção e ação das novas descobertas e de aprendizados, propiciando diversas experiências. Dessa forma, um dos meios de proporcionar desenvolvimento é a partir da Literatura infantil, pois os livros e histórias tem o poder de construir novas possibilidades de aventuras, saberes experiências, contribuindo na construção cidadã do sujeito, através da sua narração e no exercício do imaginário infantil, tal processo auxilia no brincar, na participação, expressando-se por meio da fala, se conhecendo e construindo autonomia.

É por meio dessa prática que a leitura se apresenta para a criança. Segundo Villardi (1999, p. 11) “Há que se desenvolver o gosto pela leitura, a fim de que possamos formar um leitor para toda vida". Dessa maneira, para Abramovich (2009) ouvir histórias é o início da aprendizagem para ser um leitor, é ter um caminho infinito de descobertas e compreensão do mundo, enfatiza também que o ouvir histórias é sentir, enxergar com olhos imaginários, dessa forma estimula a criança no desenvolvimento da imaginação, emoções e sentimentos de forma prazerosa e significativa, isso denota o potencial lúdico da contação de histórias.

Na visão de Bettelheim (1980), a criança através da estória poderá se identificar com um dos seus protagonistas, não só recebendo esperanças, uma vez que, é informado 
a ela que através do seu desenvolvimento e inteligência poderá se tornar vitoriosa de alguma situação ou vivência, mesmo havendo um oponente muito mais forte.

Ademais, ao se atentar para a Educação Infantil, é notável um repertório muito extenso de possibilidades de leituras e contações de histórias, tornando-se um aporte para auxílio da prática pedagógica, principalmente quando tem-se a possibilidade de realizar a leitura em uma ambientação propícia do cenário infantil, sendo possível cativar os ouvintes, dando suporte no processo de ensino aprendizagem, já que a primeira infância é marcada de forma significativa na vida de qualquer indivíduo, pois

\begin{abstract}
É na interação com os pares e com adultos que as crianças vão constituindo um modo próprio de agir, sentir e pensar e vão descobrindo que existem outros modos de vida, pessoas diferentes, com outros pontos de vista. Conforme vivem suas primeiras experiências sociais (na família, na instituição escolar, na coletividade), constroem percepções e questionamentos sobre si e sobre os outros, diferenciando-se e, simultaneamente, identificando-se como seres individuais e sociais (BRASIL, 2018, p.40).
\end{abstract}

Essa interação torna-se importante, pois é, a partir de então, que instiga a relação com os livros, uma vez que se um convite à leitura realizado de maneira cautelosa, elaborando critérios para a escolha da leitura, bem como expor compromisso e responsabilidade, aprimorando nas práticas de contação de história, torna o papel da mediação fundamental.

Na perspectiva da dialogicidade, uma das principais categorias das teorias, nasce as práticas sociais e culturais de mediação da leitura. Dessa forma, quando as leituras propostas estão relacionadas às experiências, o processo de construção do leitor não tem apenas a relevância teórica do discurso pedagógico, situa-se, também, no lugar social dos envolvidos.

Em contrapartida ao que afirma Busatto (2018), as crianças do século XXI, já nascem envolvidas em um imaginário construído pela tecnologia de ponta, a leitura e contação de histórias fazem parte do processo de comunicação cotidiana que ocorre entre os sujeitos e que envolve interações sociais e trocas, fomentadas em situações diversas, expressas pela memória, cultura, tradições e contextos sociais.

\title{
2.3 CONTAÇÃO DE HISTÓRIAS, LINGUAGEM ORAL E COVID-19
}

Como caracteriza Zumthor (2001) existem três modalidades de oralidade sendo elas: Primeira, mista e segunda. Sendo a primeira a oralidade primária, cujo representantes não comportaria nenhum contato com a escrita, a mista, os sujeitos já 
convivem com a escrita, porém, ela pouco flui entre a oralidade, a segunda, existe a apropriação da escrita e a manutenção do oral. De acordo com a modalidade secundária, a linguagem oral já advém de uma apropriação da escrita para manutenção da oralidade, nesse enfoque Busatto (2018) afirma que existem duas caracterizações de contadoras histórias, sendo ele tradicional ou contemporâneo.

O contador de histórias tradicional surge desde os primórdios, e utiliza de um ato empírico e direto, a transmissão de histórias passadas de geração para geração, assim conta memórias, heranças ou contos híbridos, o que na adesão às ideias de Zumthor (2001), seria um contador dentro da primeira modalidade de oralidade, a qual os representantes não comportam nenhum contato com a escrita.

Consequentemente, o contador de histórias contemporâneo aprende técnicas específicas, como vocalização, linguagem corporal, se apresenta em eventos, utilizando de meio tecnológicos para suas performances, que acredita no cientificismo ${ }^{4}$, à vista disso, é perceptível que este é o século de contadores contemporâneos, visto que atualmente existe formação institucionalizada para a formação de contadores de histórias, já que há, então, uma cultura relativamente "letrada", pois se apropria da escrita, da impressão e das novas tecnologias.

Vale lembrar, que a narração oral ligada ao contexto pedagógico, é encontrada dentro de documentos norteadores, como diretrizes, projetos políticos pedagógicos, planos de ensino e plano de aulas, a solicitação do exercício da contação de histórias, principalmente, tratando-se da Educação Infantil.

Quanto a isso, ao que diz a Base Nacional Comum Curricular (BNCC) (2018), a primeira infância permeia do 0 aos 5 anos de idade, e traz consigo a indicação de quais são as experiências fundamentais para que a criança aprenda e se desenvolva, apresentado por campos de experiências dentre eles, o terceiro campo escuta, fala, pensamentos e imaginação, o qual traz questões e posicionamento sobre a narração e a literatura, trabalhando noções essenciais para o processo educativo.

É perceptível que mesmo no século XXI, tempo esse considerado dos contadores contemporâneos, paralelamente, vivencia uma realidade que também sofreu mudanças drásticas, devido ao Covid-19, mas que serviu como uma oportunidade em inovar a contação de histórias. Com as mudanças oriundas do distanciamento social, os

\footnotetext{
4 Doutrina que só considera a verdade, quando comprovada por meio de métodos científicos.
} 
contadores de histórias que antes trabalhavam presencialmente, se viram diante de um novo desafio: contar histórias pela internet, através da produção de material em vídeo.

Devido às medidas de biossegurança, a ação do contador de histórias movimenta-se no espaço telemático e cibernético, ainda que as histórias perpassem por livros, e-books, plataformas de vídeo, ainda serão histórias, segundo Jouve (2002) a contação de histórias tem diversas dimensões, envolta em sentimentos e memórias que levam as pessoas a se conectarem com o que é lido, pluralidade de interpretações do que é lido e ouvido.

Neste cenário, se tratando de mediação da leitura, é importante salientar que o gosto pela leitura tem parte fundamental quanto ao mediador, já que necessita demonstrar e apresentar seu gosto pela leitura a fim de que desperte no outro o prazer de ler, sendo assim, condizente Villardi (1997) para formar grandes leitores, leitores críticos, não basta ensinar a ler, é preciso ensinar a gostar de ler com prazer, isto é possível e mais fácil do que parece. Contar histórias em meio a tantos suportes e possibilidades de leitura atraentes que hoje se apresentam, faz por parecer um grande desafio, se observado de forma pessimista.

Por outro lado, se ampliado o conceito de leitura e o significado do ato de ler para incorporar a presença da leitura no espaço virtual, Busatto (2018) afirma que a tela pequena de um computador é um lugar do detalhe precioso de um dedo que surge carregando consigo uma gama de significações, o que nas palavras de Benjamin (1985) a cada manhã recebemos notícias de todo mundo, corroborando com Santaella (2007) que descreve o perfil cognitivo da forma de contação de histórias imersa ao mundo virtual, destacando que a era digital traz um modo inteiramente novo, nas palavras de Lévy (2000) é um espaço de comunicação aberto pela interconexão mundial, sendo dessa forma o que elucida Weschenfelder (2009) o avanço da tecnologia e a velocidade das telas virtuais com recurso artístico da contação de histórias permanecem em nós.

Na perspectiva do século XXI, no ano de 2020, enfrentando uma situação atípica, aos quais foi necessário aderir ao isolamento social, visando minimizar os impactos causados, o Conselho Nacional de Educação (CNE)(2020) ao emitir um parecer sobre a reorganização do calendário escolar, acabou aderindo pelo meio digital como forma de levar atividades com caráter educativo, dessa maneira a contação de histórias se torna disponível em diferentes suportes, não sobrepondo o lúdico em detrimento do 
tecnológico, mas sim, ressignificando a contação de história no âmbito educacional, já que,

Entretanto, ainda sob os olhares de teóricos, é possível ver que para eles a tecnologia veio para mudar e transformar as práticas, mas não tomará o lugar do professor, já que a ela não lhe atribui qualidades como a paciência, a voz meiga e o olhar, assim afirma Weschenfelder (2005, p.124).

Os alunos conectados à internet não pertencem mais ao mundo da didática transmissora de conteúdos, estanques e não-interativos e que a velocidade das máquinas e das telas virtuais jamais substituirá a candura da voz, o olhar transfigurado, o jeito meigo e a paciência dos contadores de histórias no momento em que presentifica a polifonia das vozes nos livros, especialmente os de ordem literária.

Levy (1999, p. 211). nesse ponto vem aflorar e apor sobre estes pensamentos, logo que são consideráveis estas ideias para que as pessoas não se iludam com o encantamento da tecnologia, condicionando em um devaneio de substituição:

[...] é um erro pensar que o virtual substitui o real, ou que as telecomunicações e a telepresença vão pura e simplesmente substituir os deslocamentos físicos e os contatos diretos. A perspectiva da substituição negligencia a análise das práticas sociais afetivas e parece cega a abertura de novos planos de existência, que são acrescentados aos dispositivos anteriores ou os complexifica em vez de substituí-los.

Em harmonia a isso, Benjamin (1983) afirma que as descobertas de tecnologias e seu avanço se tornam um elemento ameaçador as velhas formas de narrar, pois algumas literaturas orais podem chegar com formas adversas de predicativos, o que Busatto (2018) chama de construção de uma narrativa híbrida, que venha a ser uma coletânea de histórias advindas e baseadas em contações populares de histórias tradicionais de clássicos.

Fazendo assim perceber que a contação de histórias é referência, ao se tratar de desenvolvimento na perspectiva social, lógica e racional do ser, a arte de contar histórias é uma reportação de criação de espaços de encantamento.

\section{METODOLOGIA}

Essa é uma pesquisa documental de cunho qualitativa em educação, contíguo a isso também uma análise de conteúdo, a qual pode se explorar o caráter formativo e educativo dos canais digitais e como esses podem ajudar no processo de aprendizagem, fomentando o imaginário das crianças de 04 a 06 anos. 
A análise de conteúdo, atualmente, pode ser definida como um conjunto de instrumentos metodológicos, em constante aperfeiçoamento, que se presta a analisar diferentes fontes de conteúdo sejam elas verbais ou não verbais. Faz-se necessário para tal, certo grau de intuição, imaginação e criatividade, sobretudo na definição das categorias de análise, desse modo, a condução da análise dos dados abrange várias etapas, a fim de que se possa conferir significação aos dados coletados.

Pertencendo a problemática da pesquisa, as narrativas infantis exploradas no meio tecnológico, a qual muitos sujeitos ainda têm dificuldade de acesso, visto problemas sociais enfrentados pelo país, tal qual Freitas et al. (1997) a interpretação, a análise de conteúdo transita entre dois polos: o rigor da objetividade e a fecundidade da subjetividade, jamais esquecendo, do rigor e da ética, que são fatores essenciais.

Alinhado a isso, a pesquisa em questão foi elaborada em etapas, desenvolvidas para sistematizar as ideias, caracterizando-se por sendo a primeira fase, um estudo documental, realizado através de documentos e diretrizes que regulamentam a Educação Infantil e a prática da literatura oral, como parecer do Conselho Nacional de Educação (CNE) sobre as adaptações realizadas no período de isolamento social, mediante a pandemia do Covid-19, Base Nacional Comum Curricular (BNCC), a Lei de Diretrizes e Bases da Educação 96/98 (LDB), Referencial Nacional Curricular da Educação Infantil (RCNEI), envolvendo também o levantamento de dados em periódicos de indexação de literatura de cunho acadêmico, utilizando plataformas tais como: Google Acadêmico, periódicos da Coordenação de Aperfeiçoamento de Pessoal de Nível Superior (Capes), utilizando palavras chaves infância, contação de história, literatura infantil e mediação tecnológica, como referencial para escolha de teóricos e autores que possam contribuir para o desenvolvimento do estudo, realizando nessa perspectiva um levantamento de possíveis salas digitais e plataformas, se tratando da organização do material a ser investigado.

Então, a partir dos estudos e pesquisa acerca do tema da problemática, a outra etapa pertencente a pesquisa, foi de fazer um levantamento e um mapeamento dos possíveis canais digitais que mais se destacam na plataforma YouTube com o propósito de contação da história, diante disso, foram selecionados seis canais do para se fazer a análise de conteúdo, partindo dos pressupostos de categorias de análises, se tratando acerca de como era abordado a infância, os gêneros literários, a linguagem, o tempo de duração de vídeos, o conteúdo e características. Os canais selecionados para participar 
da análise são públicos com acesso disponível para qualquer interessado, por isso irá apresentar-se com seus nomes reais sem utilizar pseudônimos, acreditando que assim contribuindo para que outras pessoas e educadores possam utilizar os resultados dessa pesquisa como suporte de escolhas para seus trabalhos didáticos ou de outra natureza. Então, foram escolhidos: Carol Levy, Fafá conta Histórias, Núbia Paiva, O baú da Camilinha, Um canto que conta e Varal de histórias.

Logo, se iniciou a exploração do material, considerando-se os delineamentos dos textos em unidades de registros, a definição de regras de contagem, as categorias de análises e a classificação e inclusão das informações, assim, utilizou-se como instrumento uma tabela comparativa, por meio de recorte, agregação e enumeração, com base em regras precisas sobre as informações textuais, representativas das características do conteúdo, então a análise comparativa, se caracteriza, como o tratamento dos resultados, interpretação, conclusão e reflexão equivalentes aos conteúdos designados.

\section{RESULTADOS E DISCUSSÕES}

A plataforma de compartilhamento de vídeos, YouTube foi criada em 2005 por dois colegas de trabalho, Chad Hurley e Steve Chen, com o objetivo principal da indexação de vídeos que fossem muito grandes e não fosse possível o seu envio por email. Hoje tornou-se a maior plataforma de vídeos do mundo, são milhões de visualizações por dia, sendo atualmente comprada e unificada pela grande empresa Google, a qual se tratou de um negócio bilionário, e como principal regra não é possível compartilhar vídeos com direitos autorais.

Por existir uma infinidade de canais nessa plataforma, sobre diferentes nichos, tratando-se de contação de histórias não é diferente, para essa pesquisa como já mencionado, foram selecionados seis, sendo eles: Carol Levy, Fafá conta Histórias, Núbia Paiva, $\mathrm{O}$ baú da Camilinha, Um canto que conta e Varal de histórias. Por proceder de uma pesquisa, com o uso da análise de conteúdo é necessário que se descreva os respectivos canais e suas características, que estão apresentadas no quadro abaixo: 
Quadro 1 - Comparações dos canais digitais, na plataforma YouTube

\begin{tabular}{|c|c|c|c|c|}
\hline $\begin{array}{l}\text { Nome do } \\
\text { canal }\end{array}$ & $\begin{array}{c}\text { № de } \\
\text { inscritos }\end{array}$ & $\begin{array}{l}\text { Tempo de } \\
\text { criação }\end{array}$ & Características & Tipos de texto \\
\hline Carol Levy & $68,5 \mathrm{mil}$ & $\begin{array}{l}\text { Desde } \\
\text { Abril } 2010\end{array}$ & $\begin{array}{l}\text { Vídeos de cinco a dez minutos, } \\
\text { com métodos de narrativa oral. } \\
\text { Apresenta uma linguagem clara } \\
\text { e usa como principal } \\
\text { instrumento de contação de } \\
\text { história um 'saco mágico'. }\end{array}$ & $\begin{array}{l}\text { Contos e histórias } \\
\text { Folclóricas, contos } \\
\text { populares, histórias da } \\
\text { literatura infantil. }\end{array}$ \\
\hline $\begin{array}{l}\text { Fafá conta } \\
\text { histórias }\end{array}$ & $190 \mathrm{mil}$ & $\begin{array}{l}\text { Desde } \\
\text { Julho de } \\
2015\end{array}$ & $\begin{array}{l}\text { Vídeos de apresentação em } \\
\text { tempo real com duração entre } \\
\text { dez e trinta minutos, vídeos de } \\
\text { três entre cinco minutos, com } \\
\text { ambientação e narrativas orais } \\
\text { com apoio visual de livros. } \\
\text { Sortido de vídeos de diferentes } \\
\text { gêneros, todos adequados para } \\
\text { a linguagem infantil. }\end{array}$ & $\begin{array}{l}\text { Clássicos da Literatura } \\
\text { infantil, infanto juvenil e } \\
\text { agregam vídeos com } \\
\text { diversos gêneros, como } \\
\text { de biografia de pessoas } \\
\text { importantes para a } \\
\text { história do mundo e datas } \\
\text { comemorativas. }\end{array}$ \\
\hline Núbia Paiva & 368 & $\begin{array}{l}\text { Desde } \\
\text { Março de } \\
2020\end{array}$ & $\begin{array}{l}\text { Vídeos entre cinco e dez } \\
\text { minutos, com narrativas orais, e } \\
\text { uso de objetos para apoio } \\
\text { visual. }\end{array}$ & $\begin{array}{l}\text { Histórias folclóricas, } \\
\text { poemas e poesias de sua } \\
\text { autoria. }\end{array}$ \\
\hline $\begin{array}{l}\text { O baú da } \\
\text { Camilinha }\end{array}$ & $34,8 \mathrm{mil}$ & $\begin{array}{l}\text { Desde } \\
\text { Julho de } \\
2014\end{array}$ & $\begin{array}{l}\text { Vídeos com duração de oito a } \\
\text { dez minutos, uso de músicas e } \\
\text { fantasias como apoio visual da } \\
\text { narrativa oral, com } \\
\text { característica especial de } \\
\text { acompanhamento musical em } \\
\text { todas as histórias. }\end{array}$ & $\begin{array}{lr}\text { Clássicos da literatura } \\
\text { infantil, } \\
\text { autorais. }\end{array}$ \\
\hline $\begin{array}{l}\text { Um canto que } \\
\text { conta }\end{array}$ & 4,28 mil & $\begin{array}{l}\text { Desde } \\
\text { Dezembro } \\
\text { de } 2015\end{array}$ & $\begin{array}{l}\text { Vídeos entre cinco a oito } \\
\text { minutos de duração, narrativas } \\
\text { orais através de musicalidade. }\end{array}$ & $\begin{array}{l}\text { Clássicos da Literatura } \\
\text { infanto-juvenil, cordéis e } \\
\text { canções. }\end{array}$ \\
\hline $\begin{array}{l}\text { Varal de } \\
\text { histórias }\end{array}$ & $386 \mathrm{mil}$ & $\begin{array}{l}\text { Desde } \\
\text { Junho de } \\
2013\end{array}$ & $\begin{array}{l}\text { Vídeos com duração de cinco a } \\
\text { dez minutos, com uso de } \\
\text { fantoches, bonecos, fantasias e } \\
\text { objetos como auxílio visual nas } \\
\text { narrativas orais. }\end{array}$ & $\begin{array}{l}\text { Clássicos da Literatura } \\
\text { Infantil. }\end{array}$ \\
\hline
\end{tabular}

Fonte: Autoria própria (2020)

A partir da análise da tabela, foi possível perceber que a maioria dos canais, já se mantinham na plataforma há algum tempo, dessa maneira os respectivos responsáveis, já utilizavam da plataforma como um instrumento para contação de histórias, e não iniciaram exclusivamente por deferência da pandemia. Ao contrário de um que se dedica exclusivamente a postar vídeos durante essa quarentena. Verificou-se também que os usos de aportes visuais como objetos fantasias e fantoches são comuns entre os 
contadores, dessa forma, as técnicas usadas para as narrativas orais são semelhantes, porém, ao mesmo tempo distintas.

Mesmo ocorrendo das tipologias textuais serem convergentes, como clássicos da Literatura Infantil, os títulos das obras narradas, suas metodologias e técnicas de apresentação nunca se igualam, com variações nas durações dos vídeos utilizam o tempo de forma diferente, determinados canais conduzem a narração através de música, em sua maioria autoral, outros da colaboração das ilustrações presentes nos livros, expondo assim, as características próprias de cada canal, visto que cada um apresenta sua singularidade.

Sendo permitido entender que as contações de histórias através da mediação tecnológica, de fato não sendo da forma tradicional no sentido de contador e ouvinte semblante a semblante, torna-se eficaz e necessária, já que foi possível perceber que contadores de histórias que utilizam da plataforma YouTube, também apresentam um contexto significativo, tendo leituras contextualizadas e apresentadas com uma linguagem clara, e abrangem em sua maioria um extenso público, visto o quantitativo de inscritos.

Sobre a qualidade do conteúdo a ser apresentado, é preciso que se desenvolvam técnicas específicas, o bom uso da voz, dos gestos, é preciso ser leitor e gostar do que faz, essas são habilidades conquistadas ao longo da vida, como afirma Machado,

\section{Um bom contador de histórias, guiado pela ação interligada da interação, ritmo e técnica, exercita habilidades pessoais-recursos internos, combinados com o amplo repertório de informações disponíveis -recursos externos-, enquanto vai polindo e conquistando, ao longo da vida, a qualidade da presença (2004, p 68).}

Como visto a qualidade da contação de histórias depende do planejamento, da escolha da história, das técnicas que serão utilizadas, foi perceptível que nos canais escolhidos, o discurso da linguagem para as crianças é realizado e elaborado de forma significativa, já que tratam a infância como uma fase do despertar da criatividade, da imaginação do desenvolvimento, dessa forma são apresentadas vários aspectos e formatos de literatura.

Por ser uma importante ferramenta na formação da identidade e valores, além de ajudar a desenvolver o imaginário, capacidades cognitivas e a inteligência emocional dos pequenos, a contação de histórias, também tem a função de "recrear, informar, transformar, curar, apaziguar e integrar" como afirma Sisto (2005, p. 88) e é notável que 
todas essas características estão sendo devidamente contempladas nesses canais citados nesta análise.

Com a mediação tecnológica, tem-se uma valiosa oportunidade de pensar e repensar em novas práticas que vêm formar e aguçar as aprendizagens há todo momento, isso, por estarem disponíveis de uma forma acessível e que pode ser ouvida e vista quantas vezes quiser, tornar-se um recurso além da sala de aula.

As histórias representam indicadores efetivos para situações desafiadoras do cotidiano, assim como fortalecem vínculos sociais, educativos e afetivos, tornando-se, também o primeiro contato com a leitura, sendo importantíssimos para a criação de novos saberes e desenvolvimentos, como portadora de significados para a prática pedagógica, não se restringe o seu papel somente ao entendimento da linguagem e neste momento de pandemia uma aliada que contribui com educadores, pais, outros sujeitos e o público infantil para explorar a partir do recurso disponível nas plataformas digitais.

\section{CONCLUSÃO}

Tornou-se possível a reflexão, de que a contação de histórias é referência ao se tratar de desenvolvimento na perspectiva social, lógica e racional do ser. A arte de contar histórias é uma representação de criação de espaços de encantamento a partir da mediação da tecnologia.

Assim, é importante que reflitam sobre as contribuições que esse novo normal trouxe para a educação, nas inovações das práticas utilizadas, usufruindo de recursos tecnológicos para o ato de contar histórias, disponibilizando conteúdo para um número maior de telespectadores e ouvintes, não ficando limitado à sala de aula, assim como aproveitar dos recursos audiovisuais, para edição de vídeos, enaltecendo ainda mais seu trabalho.

É importante ressaltar, que a transformação das práticas de contar de histórias no mundo cibernético não anula a forma tradicional de encontros, foi possível concluir que mesmo sendo um ponto importante, não é em qualquer espaço que a história está sendo contada, mas sim a maneira como as histórias são contadas, são os elementos que colaboram para o impacto delas nas pessoas.

Por fim, a contação de histórias com a mediação tecnológica se dá por meio do contato da diversidade de linguagens, formas e ferramentas utilizadas, mantendo os 
principais objetivos, valorizando a história, mas também aguçando os sentidos, estimulando a participação e dando significado ao momento de ouvir.

\section{REFERÊNCIAS}

[1] AVElar, G. M. A Palavra Poética dos Contadores. 2 ed. São Paulo: Martins Fontes, 2005.

[2] ABRAMOVICH, Fanny. Literatura infantil: gostosuras e bobices. São Paulo: Scipione, 2009.

[3] BRASIL. Ministerio da Educação e do Desporto.Conselho Nacional de Educação. Proposta de parecer sobre reorganização dos calendários escolares e realização de atividades pedagógicas não presenciais durante o período de pandemia da covid-19. Brasilia, 2020.

[4] BRASIL.LDB. Lei 9394/96 - Lei de Diretrizes e Bases da Educação Nacional. Disponível em< www.planalto.com.br. >. Acesso em 15 dez de 2020

[5] BRASIL. Base Nacional Comum Curricular: Educação Infantil. Brasília: MEC/Secretaria de Educação Básica, 2018.

[6] BRASIL. Ministério da Educação e do Desporto. Secretaria de Educação Infantil. Referencial Curricular Nacional para Educação Infantil vol.3. Brasília: MEC/SEF, 1998.

[7] BENJAMIN, Walter. O narrador. 2 ed.São Paulo: Abril Cultural,1983.

[8] BUSATTO, Cléo. A arte de contar histórias no século XXI: Tradição e ciberespaço. Petrópolis,RJ : Vozes,2018.

[9] BUSATTO. Contar e encantar: pequenos segredos da narrativa. Petrópolis, RJ: Vozes, 2012.

[10] CADEMARTORI, Lígia. O que é literatura infantil. São Paulo: Brasiliense, 1986. Coleção Primeiros Passos.

[11] CASCUDO, Luis da Câmara. Literatura oral no Brasil. São Paulo: Edição digital, 2012. Disponível em: https://www.passeidireto.com/lista/77443988literatura/arquivo/24118374-literatura-oral-no-brasil-camara-cascudo. Acessado em nov de 2020

[12] CAMILINHA.O baú da. Youtube, c2020.Página Inicial. Disponível em: https://www.youtube.com/channel/UC-MBRii7jR8UYptcacIuSNw . Acessado em: 15 dez 2020 
[13] CANDIDO, Antonio. "O direito à literatura". Rio de Janeiro: Ouro sobre azul, 2011.

[14] CONTA. Um canto que. Youtube, c2020.Página Inicial. Disponível em: https://www.youtube.com/channel/UCWR50j4vfPPu7FCpnNPXMgQ . Acessado em: 15 dez de 2020

[15] COELhO, Nelly Novaes. 0 conto de fadas. 3 ed. São Paulo: Ática, 1998. Série Princípios.

[16] FREITAS, H. M. R.; CUNHA, M. V. M., JR., \& MOSCAROLA, J. Aplicação de sistemas de software para auxílio na análise de conteúdo. Revista de Administração da USP, 32(3), 97-109, 1997.

[17] FOUCAULT, M. A Arqueologia do saber. Rio de Janeiro: Forense, 1986.

[18] HISTÓRIAS, Conta Fafá. Youtube, c2020.Página Inicial. Disponível em: https://www.youtube.com/channel/UC9fxSdFjcz5QWDEhYCk_k1w. Acessado em: 15 de dez de 2020

[19] HISTÓRIAS. Varal de. Youtube,c2020. Página inicial. Disponível em : https://www.youtube.com/user/VaraldeHistorias . Acessado em: 15 de dez de 2020.

[20] JOUVE, Vincent. A leitura. São Paulo: Unesp, 2002.

[21] LEVY, Carol. YouTube, c2020.Página inicial. Disponível em : https://www.youtube.com/user/carolinavalelevy . Acessado em: 15 de dez de 2020

[22] LEVY, Pierre. Trad. de Carlos Irineu da Costa. Cibercultura. São Paulo: Editora 34, 1999.

[23] MACHADO, Regina. Acordais: fundamentos teórico-poético da arte de contar histórias. São Paulo: DCL, 2004.

[24] MONTANDON, Alain. Du récit merveilleux ou ailleurs de l'enfance: Le Petit Prince, Le Magicien d'Oz, Peter Pan, ET, Histoire sans fin. Paris: Éditions Imago, 2011. RAMOS, Graciliano. Infância. 38. ed. Rio de Janeiro: Record, 2006.

[25] PAIVA. Nubia. Youtube, c2020.Página inicial. Disponível em: https://www.youtube.com/channel/UCF0YsPhOcKStxTMAhogpXPQ. Acessado em: 15 de dez de 2020

[26] SANTAELLA, Lucia. Navegar no ciberespaço: o perfil cognitivo do leitor imersivo. São Paulo: Paulus, 2007.

[27] SISTO, Celso. Textos e pretextos sobre a arte de contar histórias. 2. ed. Curitiba: Positivo, 2005. 
[28] VILLARDI, Raquel. Ensinando a gostar de ler: formando leitores para a vida inteira. Rio de Janeiro: Qualitymark,1997.

[29] WESCHENFELDER, Eládio Vilmar. Contar histórias: vozes contagiantes da narrativa presencial. IN: RETTENMAIER, Miguel;RÖSING, Tania. Questões de leitura no hipertexto. Passo fundo: UPF, 2005.

[30] YUNES, Eliana. Pelo avesso: a leitura e o leitor. Curitiba: Editora da UFPR, 1995. 


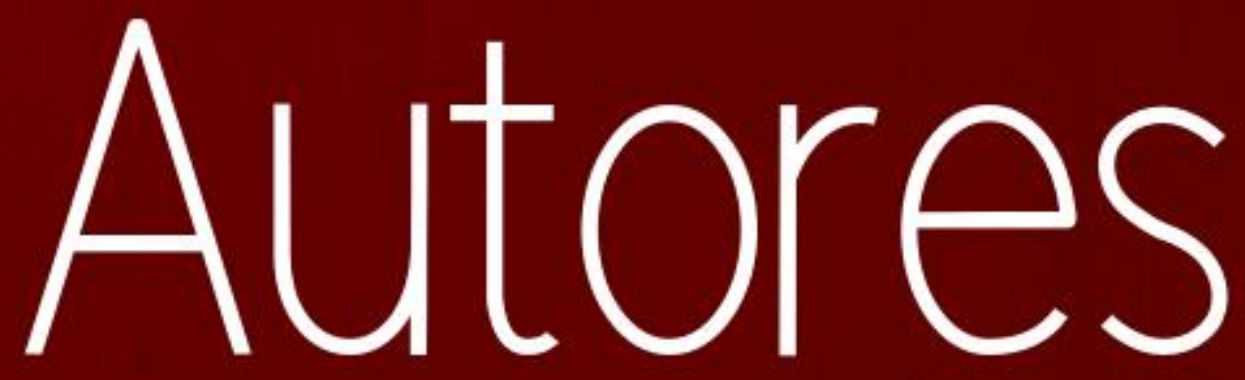




\section{Alexandre José Alves da Silva}

Graduado em Ciências Econômicas pela Universidade Federal da Bahia, Mestrado em Geociências pela Universidade Estadual de Campinas, Doutorado em Ciências pela Universidade Estadual de Campinas, Pós-doutor pela Instituto de Geociências pela UFBa/The University of Vermont, Pósgraduado em Gestão Esportiva pela Faculdade 2 de Julho e Graduando em Educação Física pela Universidade Católica do Salvador. Professor Titular do Instituto Federal da Bahia, ministra aulas no curso de Bacharelado em Administração e nos Cursos de Pós-graduação em Gestão Pública e Gestão em Saúde da Universidade Estadual da Bahia.

\section{Aline Silva Santos}

Cursando a graduação no curso de Licenciatura em Pedagogia pela Universidade do Estado da Bahia Campus XVI Departamento de Ciências Humanas e Tecnologias.

\section{Ana Karine Loula Torres Rocha}

Doutora PPGEduC/UNEB; doutorado sanduíche pela Open University - Inglaterra, atuando como pesquisadora internacional do Comitê Científico da Rede de Pesquisa Aberta COLEARN, no Knowledge Media Institute (KMi-OU). Mestre em Educação e Contemporaneidade pela UNEB, especialista em Gestão de Qualidade na Educação e em Educação a Distância, Bacharel em Administração de Empresas e Licenciada em matemática. Atua como docente na Universidade do Estado da Bahia - UNEB, DCHT Campus XVI - Irecê/Bahia. Vinculada aos grupos de pesquisa em Trabalho, Educação, Gestão e Tecnologias; Sociedade em Rede, Pluralidade Cultural e Conteúdos Digitais Educacionais.

\section{André de Oliveira Alves}

Graduando do curso de Bacharelado em Administração pela Universidade do Estado da Bahia UNEB; Técnico em Gerenciamento de Recursos Naturais pelo Instituto Federal de Educação, Ciência e Tecnologia - IFBA (2013); Membro do Grupo de Pesquisa/CNPq em Administração e Desenvolvimento Territorial, vinculado às linhas de pesquisa. Bolsista de Iniciação Científica - IC pela Fundação de Amparo à Pesquisa do Estado da Bahia / FAPESB.

\section{André Luiz Rocha de Souza}

Doutor em Engenharia Industrial pelo Programa de Pós-Graduação em Engenharia IndustrialPEI/UFBA. Mestre em Administração (2010-2012) e Especialista em Finanças Empresariais, ambos, pelo Núcleo de Pós-Graduação em Administração - NPGA/EAUFBA. Especialista em Contabilidade, Perícia e Auditoria pela Universidade Norte do Paraná, UNOPAR; MBA em Contabilidade Pública e Responsabilidade Fiscal pelo Centro Universitário Internacional UNINTER (PR). Bacharel em Ciências Contábeis pela Fundação Visconde de Cairu.

\section{Bruna da Silva Gomes}

Bacharelado em Administração, da Universidade do Estado da Bahia - UNEB, no Departamento de Ciências Humanas e Tecnologias / DCHT - Campus XVI/ Irecê. Técnica em Bicombustíveis pelo Instituto Federal da Bahia - IFBA, Campus-Irecê (2016). Membro do Grupo de Pesquisa/CNPq em Administração e Desenvolvimento Territorial, vinculado a linha de pesquisa: Gestão Solidária, Cidadania e Sustentabilidade. 


\section{Cleiton Braga Saldanha}

Pós-Graduado em Gestão Pública Municipal pela Universidade Federal da Bahia (2018); Pósgraduado MBA em Administração Pública e Gerência de Cidades pelo Centro Universitário Internacional - Uninter; Graduado em Administração pela Universidade do Estado da Bahia; Graduado em Ciências Econômicas pela Universidade Federal da Bahia. Possui experiência na área de Gestão Pública Municipal e Saúde. Pública, com ênfase em Saúde Coletiva; Experiência em Finanças Públicas.

\section{Daniela Lopes Oliveira Dourado}

Mestre em Educação de Jovens e Adultos pela Universidade do Estado da Bahia - UNEB Campus I. Especialista em Metodologia do Ensino Superior (UNEB) e Especialista em Gestão de Pessoas (FACIBA). Pedagoga pela Universidade do Estado da Bahia UNEB DCHT Campus XVI.Pós Graduanda em A Moderna Educação: Metodologias, Tendências e Foco no Aluno PUC RS. Coordenadora do grupo de Pesquisa CONPEEJA - Conjunturas de Pesquisas e Estudos em Educação de Jovens e Adultos/ CNPQ. Professora Substituta UNEB Campus XVI dos cursos de Pedagogia e Administração. Professora dos cursos de Enfermagem, Engenharia Civil, Agronomia e Direito da Faculdade Irecê FAI. Consultora em Educação e em gestão de pessoas pela ATHUS Consultoria e Gestão de Pessoas LTDA. Presidente da ONG Instituto de Permacultura em Terras Secas IPETERRAS. Membro do Conselho Municipal de Educação em Irecê.

\section{Ediane Oliveira dos Santos}

Graduada em Pedagogia-UNEB, Pós graduanda em Educação Infantil-anos iniciais e Psicopedagogia, instrumentista da Filarmônica 25 de Fevereiro de São Gabriel . Iniciação Científica: bolsista do Programa Institucional de Bolsa de Iniciação a Docência no período agosto de 2017- fevereiro 2018 na Escola Municipal São Pedro, bolsista do Programa Residência Pedagógica na Escola Municipal Paraíso, Irecê-Bahia no período outubro de 2018- janeiro de 2020A Moderna Educação: Metodologias, Tendências e Foco no Aluno.

\section{Fernando da Fonseca de Souza}

Possui graduação em Engenharia Civil pela Universidade Federal de Pernambuco (1976), mestrado em Ciências da Computação pela Universidade Federal de Pernambuco (1982) e doutorado em Ciência da Computação pela University Of Kent At Canterbury (1990). Atualmente é Professor Associado no Centro de Informática da Universidade Federal de Pernambuco.

\section{Ithany Felipe Alcântara da Silva}

Acadêmico em Licenciatura no Curso de Pedagogia, da Universidade do Estado da Bahia - UNEB, no Departamento de Ciências Humanas e Tecnologias / DCHT - Campus XVI/ Irecê. Membro do Grupo de Pesquisa/CNPq em Trabalho, Educação, Gestão e Tecnologias - GENTTES.

\section{Jerisnaldo Matos Lopes}

Pós-doutorado Propriedade Intelectual e Transferência de Tecnologia para a Inovação (IFBA); Doutor em Desenvolvimento Regional e Urbano (UNIFACS); Mestre com Linha de Pesquisa em Ética e Gestão (EST); Pós-Graduado em Gestão de Pessoas; Pós-Graduado em Gestão de Marketing e Vendas; Pós-Graduado em Docência do Ensino Superior; Pós-Graduado em Políticas Públicas Educacionais; Bacharel em Administração de Empresas com Habilitação em Marketing; Licenciado em Pedagogia; Complementação Pedagógica em Geografia; Professor do Mestrado Profissional em Tecnologias Aplicáveis à Bioenergia.; Professor do Curso de Administração. 


\section{Karine Santiago Santos}

Pós-graduanda MBA Controladoria de Empresas pela Universidade Paulista; Graduada em administração pela Universidade Estadual da Bahia-UNEB.

\section{Lívia da Silva Modesto Rodrigues}

Pós-doutorado realizado pela Universidade Portucalense/Universidade Salvador em Estudos Interdisciplinares sobre Políticas Públicas Promotoras de Igualdades (2019), Doutora em Geologia pela Universidade Federal da Bahia (2016), Mestre em Contabilidade pelo Centro de Pós-graduação e Pesquisa Visconde de Cairu - (2004), Especialista em Auditoria Fundação Visconde de Cairu (1998), Especialista em Impactos e Recuperação de Áreas Degradadas - Universidade Salvador (2014), Graduada em Ciências Contábeis - Universidade Salvador (1993) e em Administração de Empresas - Faculdade Batista Brasileira (2007). Professora Adjunta da Universidade do Estado da Bahia e Coordenadora de Tutoria dos Cursos de Administração Pública (2015-2018) e Professora do Instituto Federal de Educação, Ciência e Tecnologia da Bahia. Possui experiência em Coordenação de Curso Superior nas modalidades Presencial e à Distância na área de Ciências Contábeis e Administração Pública.

\section{Manoela Fernanda Pereira da Silva}

Mestranda em Ciências Ambientais pela Universidade Estadual de Feira de Santana (UEFS). Graduada em Administração pelo Instituto Federal de Educação, Ciência e Tecnologia da Bahia IFBA e Licenciada em Letras pela Universidade do Estado da Bahia - UNEB. Possui pós-graduação em Língua e Literatura: Mediadores da Identidade Cultural. Desenvolve pesquisa sobre os impactos sociais, econômicos e ambientais da atividade de mineração nos municípios baianos de Novo Horizonte e Boquira e nos municípios mineradores da Chapada Diamantina.

\section{Paulo André da Rocha Perris,}

Doutorado em Ciências da Computação pela Universidade Federal de Pernambuco, possui Mestrado em Ciências da Computação pela Universidade Federal de Pernambuco - UFPE (2013). Graduação em CTRA - Curso Tecnólogo em Redes e Ambientes Operac. pela União dos Institutos Brasileiros de Tecnologia - UNIBRATEC (2007).

\section{Tácio Reis Dias Pereira Valois}

Graduação em andamento em Ciências Contábeis. Universidade do Estado da Bahia, UNEB, Brasil.2007 - 2009. 
